PATRICIA DIAS BARBOZA

\title{
ANÁLISE DE DECISÃO MULTICRITÉRIO APLICADA NA SELEÇÃO DE INVESTIMENTO EM ARMAZENAGEM DE SOJA EM GRÃO
}

Dissertação apresentada à Escola Politécnica da Universidade de São Paulo para obtenção do Título de Mestre em Ciências

São Paulo 
PATRICIA DIAS BARBOZA

\section{ANÁLISE DE DECISÃO MULTICRITÉRIO APLICADA NA SELEÇÃO DE INVESTIMENTO EM ARMAZENAGEM DE SOJA EM GRÃO}

Dissertação apresentada à Escola Politécnica da Universidade de São Paulo para obtenção do Título de Mestre em Ciências

Área de concentração:

Engenharia de Sistemas Logísticos

Orientador: Professor Doutor

José Geraldo Vidal Vieira

\section{São Paulo}


Este exemplar foi revisado e corrigido em relação à versão original, sob responsabilidade única do autor e com a anuência de seu orientador.

São Paulo, de julho de 2013.

Assinatura do autor

Assinatura do orientador

FICHA CATALOGRÁFICA

Barboza, Patrícia Dias

Análise de decisão multicritério aplicada na seleção de investimento em armazenagem de soja em grão / P.D. Barboza. -versão corr. -- São Paulo, 2013.

$125 \mathrm{p}$.

Dissertação (Mestrado) - Escola Politécnica da Universidade de São Paulo. Departamento de Engenharia de Transportes. Sistemas Logísticos.

1. Grãos (Armazenagem) 2. Soja (Armazenagem) 3. Investimentos 4. Logística 5. Tomada de decisão I. Universidade de São Paulo. Escola Politécnica. Departamento de Engenharia de Transportes II. t. 


\section{RESUMO}

BARBOZA, Patricia Dias. Análise de seleção multicritério aplicada na seleção de investimento em armazenagem de soja em grão. Dissertação (Mestrado) - Faculdade de Engenharia de Sistemas Logísticos, Universidade de São Paulo, São Paulo, SP, 2013.

Na literatura vários estudos discutem uma previsão de aumento da demanda por soja no mercado mundial, como também enfatizam o aumento da safra brasileira para os próximos anos. Apesar destas previsões otimistas, insuficientes ou inadequadas, condições de infraestrutura em capacidade de armazenagem, de transportes e de portos no Brasil têm sido levadas em consideração na elaboração do Planejamento de Longo Prazo pelas empresas que comercializam soja. Esta pesquisa faz um levantamento dos principais atributos que compõem a decisão de armazenagem de soja a granel com o objetivo de construir um modelo que auxilie o processo de tomada de decisão sobre investimento em projeto de armazenagem de soja em grão, sob a visão de uma trading. A abordagem multicritério se faz necessária devido à complexidade envolvida na cadeia de soja e na escolha de um projeto propriamente dito. A seleção do método de análise multicritério foi fundamentada e direcionada através de uma análise bibliométrica sobre o assunto. O método utilizado é baseado na Teoria de Valor MultiAtributo e foi construído no software V.I.S.A. para eleger um projeto dentre as alternativas disponíveis. Os pesos dos critérios representam as preferências de um grupo coletadas a partir da aplicação de questionários a dez profissionais do setor. Os valores dos pesos resultaram da comparação paritária proposta pelo método Processo Analítica Hierárquico (AHP) e agregados pelo método de Agregação Individual de Prioridades. A árvore da decisão obtida foi composta pelos critérios: "localização e transporte", "estudo de mercado", "infraestruturas e aspectos regionais", "aspectos de engenharia", "análise de viabilidade econômica" e “capacidade e eficiência operacional”. Os resultados foram complementados por um exemplo hipotético elaborado para validar o modelo construído através de análises de sensibilidade e robustez. Conclui-se que o modelo se mostra coerente em relação ao perfil das alternativas criadas e recomenda-se sua utilização por tomadores de decisão de uma trading como referência para compor a sua própria árvore de decisão, e as preferências obtidas podem auxiliar processos de tomadas de decisão reais.

Palavras-chave: Análise de Investimento, Multicritério, MAVT, Armazenagem de Soja. 


\section{ABSTRACT}

BARBOZA, P. D. Análise de seleção multicritério aplicada na seleção de investimento em armazenagem de soja em grão. Dissertação (Mestrado) - Faculdade de Engenharia de Sistemas Logísticos, Universidade de São Paulo, São Paulo, SP, 2013.

Several studies in literature discuss an increasing demand for soybean worldwide and increasing supply of Brazilian grain harvest for the next few years. Despite these optimistic forecasts, insufficient or inadequate infrastructure in terms of storage capacity, transportation system and ports elevation in Brazil have been taken into account in Long Term Planning of agribusiness companies. This research is a survey of the main attributes in decision-making process of bulk warehouse for soybeans in order to build a model of this specific process under the vision of a trading company. A multicriteria approach is necessary due to the complexity involved in the soy supply chain and project selection itself. The multicriteria decision method (MCDM) selection was based and directed through a bibliometric analysis about the MCDM topic. The method used is based on the Theory of Multi-Attribute Value and was built in software VISA to choose a project among the available alternatives. The weights of each criteria were compound of a group decision that was obtained from the questionnaires of eleven professionals. The responses of the weights were based on pair-wise comparison proposed by the Analytic Hierarchy Process method, known as AHP and aggregated by Aggregation of Individual Priorities method. The decision tree of this study was composed by the criteria: "location and transportation", "market research", "infrastructure and regional aspects", "engineering aspects", "economic viability analysis" and "capacity and operational efficiency." Besides a hypothetical example were designed to validate the model using sensitivity and robustness analysis. It is concluded that the model is consistent over the profile among created alternatives and this study is recommended as reference for decision makers of a trading company to build its own tree decision. And preferences used in this study may help in real world of decision-making processes.

Keywords: Investment Analysis, MCDA, MAVT, Soybean Warehouse. 


\section{LISTA DE FIGURAS}

Figura 1 - Composição da armazenagem agrícola no Brasil ................................................ 19

Figura 2 - Evolução da capacidade estática e produção de soja e milho no Brasil..................21

Figura 3 - Evolução da Capacidade Dinâmica e Produção de Soja e Milho no Brasil no

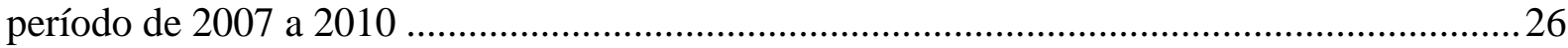

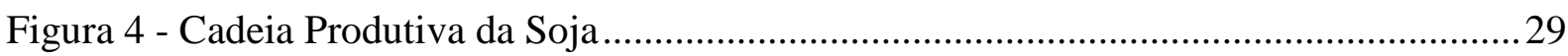

Figura 5 - Representação gráfica das relações de comercialização região importadora e região

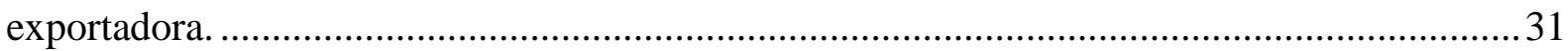

Figura 6-Curva de custo total para estratégia simples e mista de armazenagem....................34

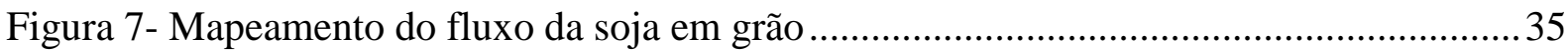

Figura 8 - Esboço de uma unidade armazenadora .............................................................. 36

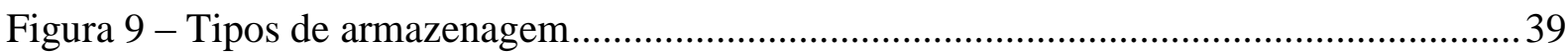

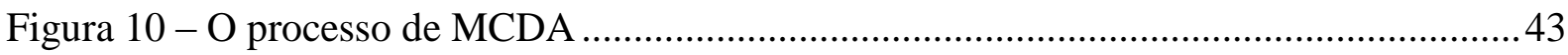

Figura 11 - Publicações de Análise Multicritério de Decisão de 1974 a 2011 ......................... 48

Figura 12- Os 5 principais métodos mais citados na base da análise bibliométrica................. 48

Figura 13 - Principais periódicos que publicam sobre o MCDA...........................................50

Figura 14 - Compensação de Custos para determinação do total de depósitos de um sistema

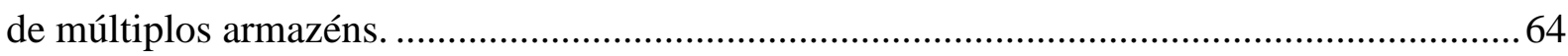

Figura 15 -. Representação do processo de tomada de decisão de investir em armazenagem. 70

Figura 16 - Exemplo genérico de uma árvore de decisão ................................................... 71

Figura 17 - Ilustração de funções de valor linear e não linear no software V.I.S.A................ 76

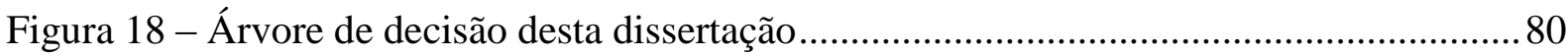

Figura 19- Classificação dos decisores quanto à importância dos critérios............................. 81

Figura 20 - Resultado dos decisores referente ao critério "localização e transporte" .............82

Figura 21 - Resultado dos decisores referente ao critério "Estudo de Mercado" ................... 83

Figura 22 - Comportamento dos pesos referente ao critério "Infraestrutura e aspectos

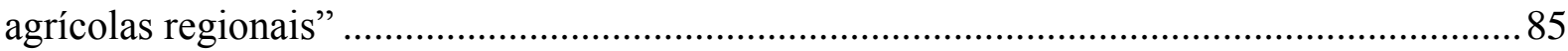

Figura 23 - Resultado dos decisores referente ao critério "Análise de Viabilidade Econômica"

Figura 24 - Resultado dos decisores referente ao critério "Aspectos de engenharia" .............87

Figura 25 - Resultado dos decisores referente ao critério "Capacidade e Eficiência

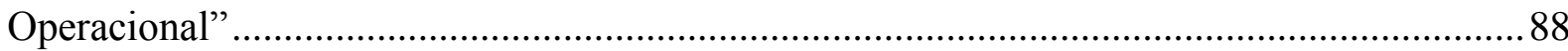

Figura 26 - Resultados do Teste de Consistência para os critérios ........................................ 91

Figura 27 - Resultados dos projetos por critério obtidos a partir da modelagem no software

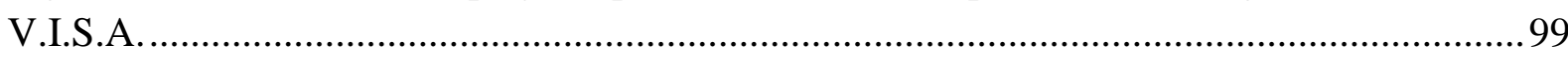

Figura 28 - Resultado da decisão de investimento proposto pelo modelo construído............101 Figura 29 - Resultado da análise de sensibilidade no software V.I.S.A. com as condições necessárias para que o modelo selecione o projeto A como melhor alternativa .................... 102 Figura 30 - Resultado da análise de sensibilidade no software V.I.S.A. com as condições necessárias para que o modelo selecione o projeto B como melhor alternativa..................... 103

Figura 31 - Análise de sensibilidade dos critérios quanto à mudança nos pesos................... 103

Figura 32 - Escala para comparar os critérios e atributos do questionário ........................... 117 
Figura 33 - Questionário enviado para os tomadores de decisão.

Figura 34 - Resultado dos decisores referente ao atributo "localização"

Figura 35 - Resultado dos decisores referente ao atributo "preço de frete da região".

Figura 36 - Resultado dos decisores referente ao atributo "frota disponível na região" 119

Figura 37 - Resultado dos decisores referente ao atributo "Modais de recepção e expedição"

Figura 38 - Resultado dos decisores referente ao atributo "Concorrência".

Figura 39 - Resultado dos decisores referente ao atributo "Aumento de Produção (Oferta)"

Figura 40 - Resultado dos decisores referente ao atributo "Demanda de Produto"

Figura 41 - Resultado dos decisores referente ao critério "Infraestrutura e aspectos agrícolas regionais".

Figura 42 - Resultado dos decisores referente ao atributo "Aspectos agrícolas" .................. 121

Figura 43 - Resultado dos decisores referente ao atributo "Demanda de Armazenagem" .... 122

Figura 44 - Resultado dos decisores referente ao atributo "Aspectos Sociais" ..................... 122

Figura 45 - Resultado dos decisores referente ao critério "Análise de Viabilidade Econômica"

Figura 46 - Resultado dos decisores referente ao atributo "VPL"

Figura 47 - Resultado dos decisores referente ao atributo "Quantificação e qualificação dos custos fixos e variáveis"

Figura 48 - Resultado dos decisores referente ao critério "Capacidade e Eficiência

Operacional"

Figura 49 - Resultado dos decisores referente ao atributo "Capacidade estática".

Figura 50 - Resultado dos decisores referente ao atributo "Eficiência dos sistemas e linhas de processamento"....

Figura 51 - Resultado dos decisores referente ao atributo "Utilização (Giros de Armazém)" 


\section{LISTA DE TABELAS}

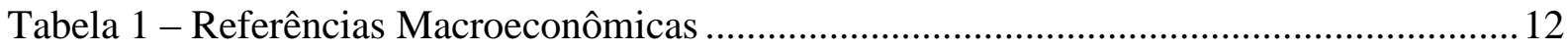

Tabela 2 - Projeções de Safras 2010/2011 a 2020/2021...................................................... 12

Tabela 3 - Comparação da produção x capacidade estática de armazenagem no Brasil nos anos de 2007 a 2010

Tabela 4 - Comparação da produção x capacidade estática de armazenagem na região Centro-

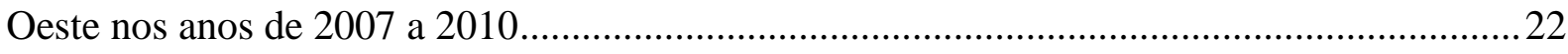

Tabela 5 - Comparação da produção x capacidade estática de armazenagem na região

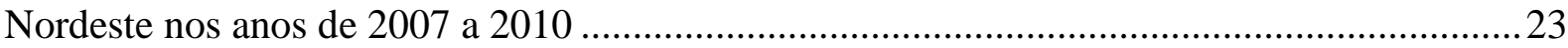

Tabela 6 - Comparação da produção x capacidade estática de armazenagem na região Sudeste nos anos de 2007 a 2010 .23

Tabela 7 - Comparação da produção x capacidade estática de armazenagem na região Sul nos anos de 2007 a 2010

Tabela 8 - Comparação da produção x capacidade estática de armazenagem na região Norte nos anos de 2007 a 2010

Tabela 9 - Resumo da Deficiência ou Superavit de Capacidade Estática de Armazenagem .. 25 Tabela 10 - Comparação da produção x capacidade dinâmica de armazenagem no Brasil nos anos de 2007 a 2010

Tabela 11 - Comparação da produção x capacidade dinâmica de armazenagem na região Nordeste nos anos de 2007 a 2010

Tabela 12 - Comparação da produção x capacidade dinâmica de armazenagem na região Norte nos anos de 2007 a 2010.

Tabela 13 - Resumo da Deficiência ou Superavit de Capacidade Dinâmica de Armazenagem 


\section{LISTA DE QUADROS}

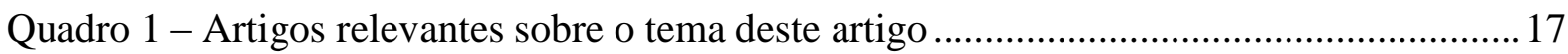

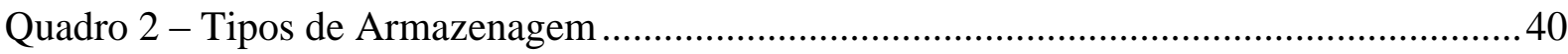

Quadro 3 - Resumo das classificações dos métodos de análise de multicritério MCDA........46

Quadro 4 - As principais características dos métodos ..........................................................49

Quadro 5 - Publicações dos autores com mais publicações de MAUT na base de dados

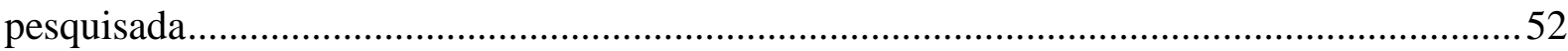

Quadro 6 - Principais parâmetros para seleção de um projeto de armazenagem granel para soja

Quadro 7 - Resumo dos critérios de localização de instalações que podem ser utilizados na

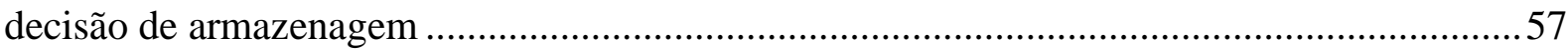

Quadro 8- Variáveis que podem influenciar a precificação do frete ......................................59

Quadro 9 - Resumo da Instrução Normativa №29 que regulamenta a certificação de armazéns granéis

Quadro 10 - Etapas para a definição e ponderação dos critérios .............................................. 74

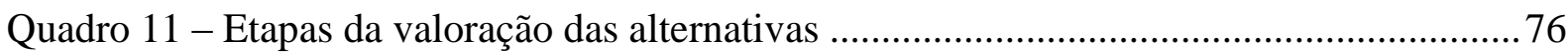

Quadro 12 - Resultados das hierarquias por decisor ........................................................ 81

Quadro 13 - Resultados das preferências relativas dos atributos dados pelos decisores

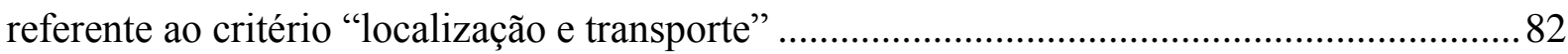

Quadro 14- Resultados das preferências relativas dos atributos dados pelos decisores referente ao critério "Estudo de Mercado"

Quadro 15 - Resultados das preferências relativas dos atributos dados pelos decisores referente ao critério "infraestrutura e aspectos regionais"

Quadro 16- Resultados das preferências relativas dos atributos dados pelos decisores referente ao critério "análise de viabilidade econômica" 86

Quadro 17 - Resultados das preferências relativas dos atributos dados pelos decisores referente ao critério "Capacidade e Eficiência Operacional".

Quadro 18 - Resultado global da preferência dos decisores .................................................. 89

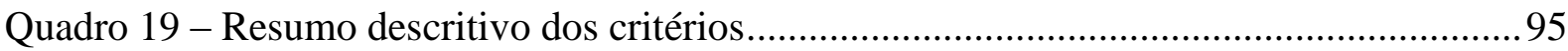

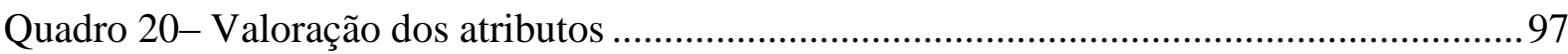




\section{SUMÁRIO}

1. INTRODUÇÃO: CARACTERIZAÇÃO DO PROBLEMA...................................................12

1.1 JUSTIFICATIVA E RELEVÂNCIA DA PESQUISA ............................................................14

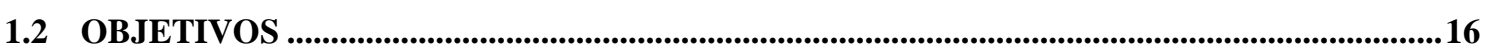

1.3 ESCOPO E JUSTIFICATIVA DO MÉTODO …...............................................................17

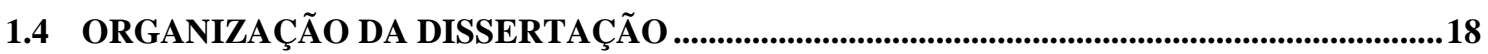

2 CENÁRIO BRASILEIRO DO ARMAZENAMENTO DE SOJA ............................................19

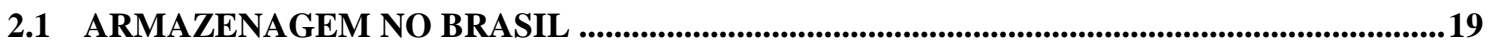

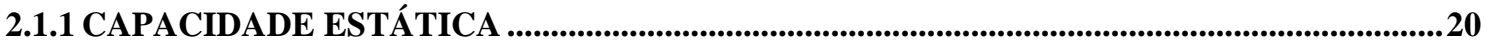

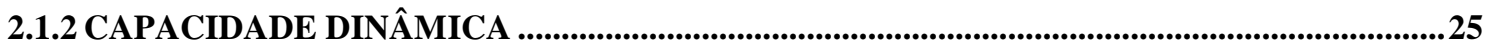

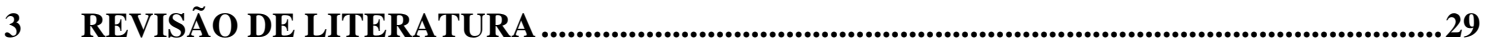

3.1 A CADEIA DE SOJA ..........................................................................................................29

3.1.1 FATORES QUE INFLUENCIAM A GESTÃO DA CADEIA DA SOJA .................................30

3.1.2 FLUXO DA SOJA ............................................................................................................................................34

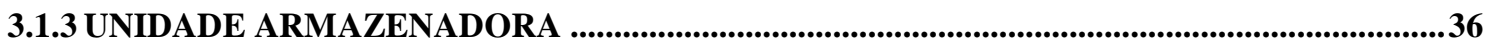

3.1.3.1 FLUXO DA SOJA NA UNIDADE ARMAZENADORA ...................................................

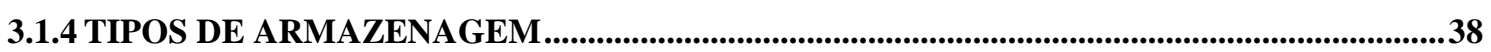

3.2 MÉTODO DE ANÁLISE MULTICRITÉRIO DE APOIO À DECISÃO......................................41

3.2.1 INFLUÊNCIAS DAS ESCOLAS AMERICANAS E EUROPEIA .............................................41

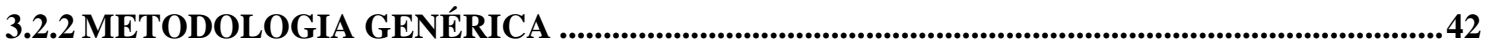

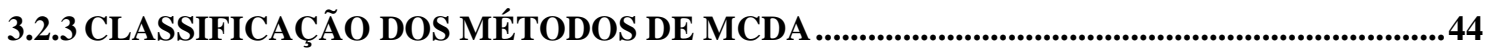

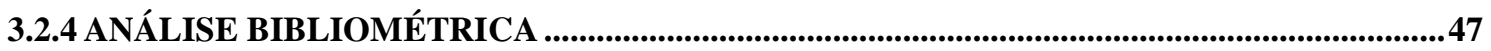

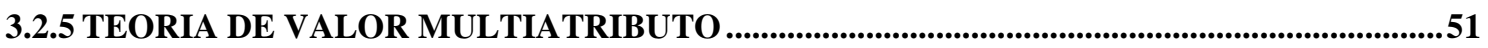

3.3 MÉTODOS E CRITÉRIOS UTILIZADOS NA LOGÍSTICA DE ARMAZENAGEM E DISTRIBUIÇÃO ................................................................................................................................................53

3.3.1 LOCALIZAÇÃO E TRANSPORTE ......................................................................................57

3.3.2 ESTUDO DE MERCADO ................................................................................................................60

3.3.3 INFRAESTRUTURA E ASPECTOS REGIONAIS......................................................................61

3.3.4 ANÁLISE DE VIABILIDADE ECONÔMICA ....................................................................61

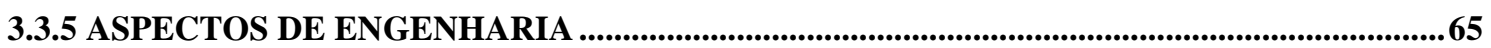

3.3.6 CAPACIDADE E EFICIÊNCIA OPERACIONAL ............................................................................67

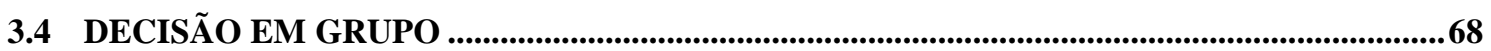

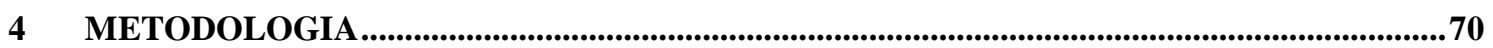

4.1 ETAPA 1 - IDENTIFICAR E ESTRUTURAR O PROBLEMA................................................71

4.2 ETAPA 2 - CONSTRUIR O MODELO MULTICRITÉRIO........................................................72

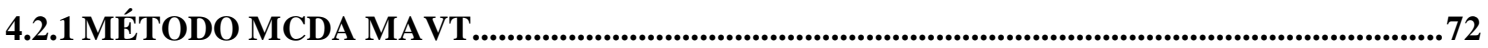


4.2.2 DEFINIÇÃO DOS PESOS.....................................................................................................

4.2.3 DETERMINAÇÃO DA ESCALA DE VALOR ................................................................................74

4.3 ETAPA 3 - APLICAR O MODELO EM UM EXEMPLO HIPOTÉTICO - USO DO SOFTWARE V.I.S.A. ........................................................................................................................................................

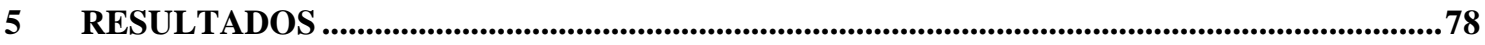

5.1 ETAPA 1 - IDENTIFICAÇÃO E ESTRUTURAÇÃO DO PROBLEMA .....................................78

5.2 ETAPA 2 - CONSTRUÇÃO DO MODELO MULTICRITÉRIO................................................8

5.2.1 ETAPA 2 - DEFINIÇÃO DOS PESOS DE CRITÉRIOS E ATRIBUTOS .................................80

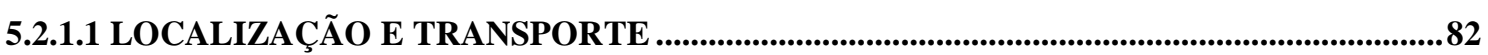

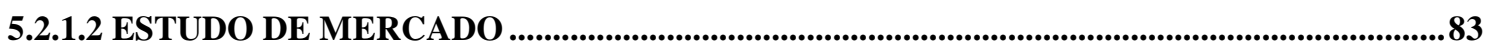

5.2.1.3 INFRAESTRUTURA E ASPECTOS REGIONAIS............................................................84

5.2.1.4 ANÁLISE DE VIABILIDADE ECONÔMICA ..............................................................................86

5.2.1.5 ASPECTOS DE ENGENHARIA .....................................................................................................87

5.2.1.6 CAPACIDADE E EFICIÊNCIA OPERACIONAL .......................................................................87

5.2.1.7 HIERARQUIA GLOBAL DOS ATRIBUTOS ..............................................................................89

5.2.1.8 TESTE DE CONSISTÊNCIA _.....................................................................................................90

5.2.2 ETAPA 2 - DEFINIÇÃO DAS ESCALAS DE VALOR DOS ATRIBUTOS …………...............91

5.2.2.1 LOCALIZAÇÃO E TRANSPORTE .......................................................................................91

5.2.2.2.ESTUDO DE MERCADO ............................................................................................................92

5.2.2.3 INFRAESTRUTURA E ASPECTOS REGIONAIS...................................................................93

5.2.2.4 ANÁLISE DE VIABILIDADE ECONÔMICA ......................................................................93

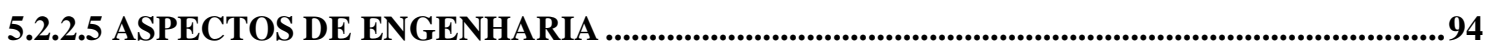

5.2.2.6 CAPACIDADE E EFICIÊNCIA OPERACIONAL ............................................................94

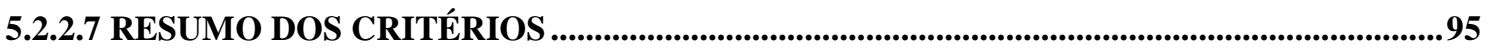

5.2.3 VALORAÇÃO DAS ALTERNATIVAS...................................................................................96

5.3 ETAPA 3 - APLICAR O MODELO A UM EXEMPLO - USO DO SOFTWARE V.I.S.A.........98

5.3.1 ANÁLISE DE SENSIBILIDADE E ROBUSTEZ...................................................................101

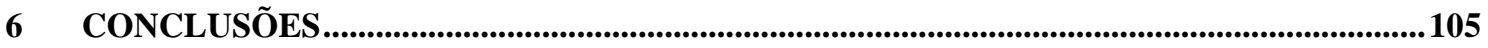

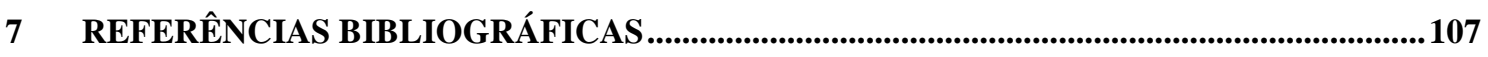

APÊNDICE A - QUESTIONÁRIO INDIVIDUAL PARA SELEÇÃO E PESOS DOS CRITÉRIOS117 APÊNDICE B - RESULTADOS DOS QUESTIONÁRIOS SOBRE OS ATRIBUTOS 


\section{INTRODUÇÃO: Caracterização do problema}

Historicamente, a agricultura é conhecida pelo seu importante papel na economia brasileira. Dados recentes mostram que essa importância se mantém como mostra a Tabela 1. Em 2011, a Agricultura movimentou R\$ 639 bilhões, o que representou $15 \%$ do Produto Interno Bruto (PIB) nacional (CEPEA, 2012; IBGE 2012). Além dessa relevante participação no PIB, o complexo da soja em 2011 foi responsável por US\$ 24 bilhões (9\%) dos US\$ 256 bi do total exportado, assumindo a $4^{\circ}$ posição de setores mais exportadores (MDIC, 2012).

\section{Tabela 1 - Referências Macroeconômicas}

\begin{tabular}{lcccccc}
\hline & 2006 & 2007 & 2008 & 2009 & 2010 & 2011 \\
\hline A) PIB brasileiro & 2.976 & 3.181 & 3.258 & 3.363 & 3,675 & 4.143 \\
B) PIB do Agronegócio brasileiro & 847 & 870 & 836 & 776 & 879 & 918 \\
C) PIB de Agricultura & 555 & 593 & 622 & 589 & 617 & 639 \\
\hline
\end{tabular}

Fonte: (CEPEA, 2012) e (IBGE, 2012)

Essa importância econômica da cadeia da soja no cenário nacional tem grande potencial de manutenção com a previsão otimista de aumento da produção para os próximos anos no Brasil. As estimativas para soja em grão indicam uma produção de 86,5 milhões de toneladas em 2020/2021. Esta projeção é 17,8 milhões de toneladas em relação ao que o Brasil produziu na safra de 2010/2011 (vide Tabela 2).

Tabela 2 - Projeções de Safras 2010/2011 a 2020/2021.

\begin{tabular}{rccc}
\hline Ano & Produção (milhões ton) & Consumo (milhões ton) & $\begin{array}{c}\text { Exportação (milhões } \\
\text { ton) }\end{array}$ \\
\hline $2010 / 11$ & 68,72 & 37,62 & 29,30 \\
$2011 / 12$ & 71,14 & 38,61 & 30,90 \\
$2012 / 13$ & 72,76 & 39,35 & 32,99 \\
$2013 / 14$ & 74,53 & 40,14 & 33,57 \\
$2014 / 15$ & 76,24 & 40,92 & 34,26 \\
$2015 / 16$ & 77,96 & 41,70 & 35,71 \\
$2016 / 17$ & 79,67 & 42,49 & 36,97 \\
$2017 / 18$ & 81,39 & 43,27 & 37,67 \\
$2018 / 19$ & 83,10 & 44,05 & 38,60 \\
$2019 / 20$ & 84,81 & 44,83 & 39,77 \\
$2020 / 21$ & 86,53 & 45,61 & 40,74 \\
\hline
\end{tabular}

Fonte: MAPA, 2011

A taxa de crescimento anual prevista para a produção é de $2,3 \%$ no período de projeção 2010/11 a 2020/21. Esta taxa está próxima da taxa mundial para os próximos dez anos, 
estimada pelo FAPRI (2010) em 2,3\% ao ano (MAPA, 2011). As taxas projetadas para consumo nacional e exportação de soja são, respectivamente, 1,9\% e 3,2\%. Observa-se que a previsão é aumentar os volumes de soja em grão exportados.

A importância econômica da cadeia da soja no cenário nacional e a previsão otimista de aumento da produção para os próximos anos no Brasil motiva a realização de pesquisas sob o ponto de vista da logística de armazenagem e distribuição, frente aos desafios esperados para a implantação adequada no atendimento da demanda.

Nesse sentido, alguns trabalhos já apontam desafios em relação à falta de infraestrutura de armazenagem e transporte e sua capacidade em acompanhar o crescimento econômico que o país vem apresentando. No Plano Nacional de Logística e Transportes de 2007 do Governo Federal verifica-se a necessidade de adequar o sistema de transportes diante do cenário de produção do agronegócio brasileiro e que gargalos no sistema rodoviário poderão ser superados pela transferência de parte dos fluxos de carga para outros modais, como ferrovias, hidrovias e cabotagem, o que contribuiria para melhor racionalização da matriz de transportes do País. Anderson et al (2009) obtiveram resultados que mostram que a exportação de granéis agrícolas do Centro-Oeste irá se expandir além da capacidade portuária, que irá apresentar um deficit de $54 \mathrm{Mt}$, o que equivale a uma necessidade de até 15 novos terminais.

Quanto à capacidade estática de armazenagem, Gallardo et al (2010) salientam que atualmente no Brasil esta já se encontra inferior ao nível recomendado pela FAO (Fundação da Organização das Nações Unidas para a Agricultura e a Alimentação), em cerca de 70 Mt, e o setor não responde ao crescimento acentuado da produção agrícola e nem às mudanças na distribuição geográfica da produção. Além disso, a estocagem na própria unidade produtora no Brasil é de apenas $15 \%$ da capacidade estática total, contra 85\% na Austrália, 65\% nos EUA, 50\% em média na Europa, $40 \%$ na Argentina e 35\% no Canadá.

A combinação do aumento da produção e a limitada infraestrutura logística vêm apresentando ineficiência na prestação de serviços e aumento dos custos com pagamentos em estadias rodoviárias, ferroviárias e portuárias. Como dificilmente nas condições brasileiras se operaria em um eficiente sistema just-in-time, a montagem de um sistema de armazenagem nos pontos relevantes de distribuição (propriedades rurais, armazéns gerais, portos e processadores) para o escoamento das colheitas sazonais pode ser uma questão estratégica. Com isso, seriam criadas condições para um equilíbrio entre oferta e demanda de serviços de transporte em 
picos de safras e, em consequência, seriam reduzidas as fontes de pressão sobre os fretes, (NOGUEIRA JUNIOR e TSUNECHIRO, 2005).

Um estudo realizado pela USDA - United States Departament of Agriculture - compara os custos de exportação de soja de algumas regiões do Brasil e dos EUA para Xangai, na China. A disparidade dos custos de frete interno entre os dois países fica bem evidente. Nos EUA, o custo de transporte, incluindo o frete marítimo, representa $29 \%$ do custo total, enquanto que, para o Brasil, esse número é algo em torno de 40\%, (NOGUEIRA et al, 2008 b).

\subsection{Justificativa e Relevância da Pesquisa}

Apesar desta necessidade iminente de investimento em armazenagem para a cadeia da soja, a tomada de decisão neste tipo de investimento por uma empresa privada não é simples. Pois, basear em somente um objetivo, por exemplo, de atendimento da necessidade de capacidade estática, é insuficiente e, provavelmente, outros critérios conflitantes como custo e retorno do investimento e qualitativos, como a percepção dos tomadores de decisão devem ser considerados. Assim, este é um problema circunscrito em um problema de tomada de decisão de natureza estratégica e que, portanto, envolve incerteza e complexidade.

Gomes et al (2002) explica que para ser considerada um processo de tomada de decisão complexo tais problemas devem apresentar pelo menos algumas das seguintes características:

a) Para a resolução do problema são levados em consideração pelo menos dois critérios e os mesmos podem ser conflitantes entre si;

b) Tanto os critérios como alternativas de solução não são claramente definidos e as suas consequências da escolha de uma dada alternativa com relação a pelo menos um critério não são claramente compreendidas;

c) Os critérios e as alternativas podem estar interligados, de tal forma que um critério parece refletir parcialmente outro critério, ao passo que a eficácia da escolha de uma alternativa depende da alternativa ter sido ou não também escolhida, no caso em que as alternativas não são mutuamente exclusivas;

d) A solução do problema depende de um conjunto de pessoas, cada uma das quais tem seu próprio ponto de vista, muitas vezes conflitante com as demais; 
e) As restrições do problema não são bem definidas, podendo haver alguma dúvida a respeito do que é critério e do que é restrição;

f) Alguns dos critérios são quantificáveis, ao passo que outros, só o são por meio de julgamentos de valor efetuados sobre uma escala;

g) A escala para dado critério pode ser cardinal, verbal, ordinal ou razões dependendo dos dados disponíveis e da própria natureza dos critérios.

Todas essas características são contempladas no tema que será tratado por esta dissertação, a complexidade de tratar a tomada de decisão sugere um método multicritério.

Portanto, ao considerar a complexidade no tratamento de vários critérios e a avaliação das alternativas, a Multi-Criteria Decision Making (MCDM) ou Multi-Criteria Decision Analysis (MCDA) é um exemplo de metodologia que auxilia o decisor na tomada de decisão usando suas próprias preferências em casos onde mais de um critério tem características conflitantes. Resumidamente, pode se dizer que é um jeito de lidar com um problema complexo subdividido em partes menores. Estas partes são analisadas e ponderadas separadamente pelos decisores e o MCDM propõe um mecanismo formal para integrar os resultados e sugerir a decisão mais adequada para o modelo definido (GOODWIN e WRIGHT, 2004; BARFORD; 2011).

Como contribuição, a pesquisa visa gerar um modelo de análise de decisão multicritério que leve em consideração atributos de valor para a tomada de decisão de armazenagem de soja em grão sob a visão de uma trading. 


\subsection{Objetivos}

Esta dissertação apresenta como ponto de partida para análise de decisão em armazenagem, o cenário atual de armazenagem agrícola no Brasil e as projeções da produção de soja nos próximos 10 anos. Isto se faz necessário para defender claramente os critérios relevantes dessa decisão, segundo os objetivos fundamentais de decisões logísticas.

Portanto, com base no referencial teórico e questionários aplicados respondidos por pessoas com experiência na área, a principal pergunta a ser respondida por esta pesquisa é: "Quais atributos considerar num processo de tomada de decisão de projeto de unidade armazenadora mais adequados na visão de uma empresa privada do setor?"

Para responder a esta pergunta será utilizado um método de análise de decisão multicritério, baseado na Teoria de Valor Multiatributo, também conhecida como Mult-Atributed Value Theory (MAVT), como apoio à construção de um modelo que leve em consideração atributos de valor. Este modelo tem base na teoria de utilidade que foi usada na dissertação de maneira implícita, por meio das curvas de valor e para cálculo dos pesos dos atributos de um exemplo hipotético. Portanto, o objetivo principal é propor um modelo multicritério que auxilie o processo de tomada de decisão sobre investimento em armazenagem granel sob a visão de uma trading do setor.

Os objetivos específicos deste trabalho são:

- Identificar na literatura os critérios relevantes para a abordagem multiatributo em decisão de armazenagem e considerar aqueles que são peculiares à decisão logística;

- Desenvolver um modelo multicritério de investimento em armazenagem que possa ser utilizado por uma empresa do setor para avaliação de alternativas de decisão de armazenagem. 


\subsection{Escopo e justificativa do método}

Embora esta dissertação vise propor um modelo adequado de análise de decisão multicritério para auxiliar a tomada de decisão de investir numa instalação de armazenagem para soja em grão por um decisor logístico, foram observadas poucas pesquisas sobre o tema utilizando a metodologia de MCDA. Segundo Abbas et al (2011) em sua pesquisa de metodologias de MCDA, no período de 1999 a 2009 foram encontrados 12 artigos relevantes sobre o tema Gerenciamento Agrícola e Florestal. Os artigos e os respectivos métodos para análise se encontram na Tabela 3.

\section{Quadro 1 - Artigos relevantes sobre o tema deste artigo}

\begin{tabular}{|c|c|c|}
\hline Autor & Área de Aplicação & Ferramenta/Metodologia Utilizada \\
\hline 1. $\quad$ Agrell et al (2004) & $\begin{array}{l}\text { Planejamento Regional do } \\
\text { Desenvolvimento Agrícola }\end{array}$ & $\begin{array}{l}\text { Multi-criteria Decision Support } \\
\text { System (DSS) } \\
\end{array}$ \\
\hline 2. $\quad$ Ananda e Herath (2009) & Gerenciamento Florestal & Análise dos Métodos de MCDM \\
\hline 3. André e Riesgo & Economia Agrícola & $\begin{array}{c}\text { Multiatribute Utility Theory } \\
\text { (MAUT) }\end{array}$ \\
\hline 4. Calker et al (2006) & $\begin{array}{l}\text { Sistemas de produção leiteiro } \\
\text { holandês }\end{array}$ & $\begin{array}{c}\text { Multiatribute Utility Theory } \\
\text { (MAUT)-Goal Programming (GP) }\end{array}$ \\
\hline 5. Cook e Proctor (2007) & $\begin{array}{l}\text { Ameaça de plantas exóticas por } \\
\text { pragas }\end{array}$ & $\begin{array}{c}\text { Avaliação multicritério } \\
\text { deliberativa }\end{array}$ \\
\hline 6. Gomez-Limon et al (2003) & Análise de risco agrícola & $\begin{array}{l}\text { Multiatribute Utility Theory } \\
\text { (MAUT) }\end{array}$ \\
\hline 7. $\quad$ Kazana et al (2003) & Gerenciamento Florestal & MIN-MAX \\
\hline 8. López et al (2008) & $\begin{array}{c}\text { Integração de um sistema } \\
\text { produtivo orgânico de oliva }\end{array}$ & Analytic Hierarchy Process (AHP) \\
\hline 9. $\quad$ Sarker e Quaddus (2002) & Planejamento agrícola & Gol Programming \\
\hline 10. Sell et al (2006) & $\begin{array}{c}\text { Projetos ambientais para florestas } \\
\text { tropicais }\end{array}$ & Mean values - ANOVA \\
\hline 11. Strassert and Prato (2002) & Seleção de sistemas de produção & $\begin{array}{l}\text { Balancing and Ranking Method } \\
\text { (New MCDM Method) }\end{array}$ \\
\hline 12. Vainikainen et al (2008) & $\begin{array}{l}\text { Gerenciamento florestal de mata } \\
\text { nativa }\end{array}$ & $\begin{array}{l}\text { Multi-criteria Decision Support } \\
\text { System (DSS) }\end{array}$ \\
\hline
\end{tabular}

Fonte: Abbas et al (2011)

Observa-se que o método MCDA mais utilizado neste campo amostral é o MAUT e que nenhum dos trabalhos referenciados por Abbas et al (2011) tem alguma relação à decisão deste trabalho de armazenagem agrícola a granel, o que sinaliza uma limitação de referência e comparação de trabalhos MCDA no tema estudado. 


\subsection{Organização da dissertação}

Esta dissertação está organizada da seguinte maneira:

- Capítulo 1 - Introdução: Apresenta uma visão geral sobre o assunto, os objetivos do trabalho, suas limitações, escopo e justificativa do método e a organização da dissertação.

- Capítulo 2 - Cenário Brasileiro: Apresenta uma discussão do cenário atual de armazenagem agrícola no Brasil.

- Capítulo 3 - Revisão de literatura: Apresenta a importância da cadeia da soja, uma análise bibliométrica dos principais métodos de Multi-Criteria Decision Analysis (MCDA) e da Teoria de Valor Multiatributo, também conhecida como Mult-Atributed Value Theory (MAVT) e os critérios utilizados para a construção do modelo de decisão.

- Capítulo 4 - Metodologia: Apresenta as etapas do processo de tomada de decisão multicritério e da Teoria de Valor Multiatributo.

- Capítulo 5 - Resultados: Apresenta os resultados obtidos nas etapas do processo de tomada de decisão multicritério e da Teoria de Valor Multiatributo.

- Capítulo 6 - Conclusões: Apresenta as conclusões mais relevantes deste trabalho, assim como limitações e recomendações para trabalhos futuros.

- Apêndice A: Questionário individual para seleção de critérios.

- Apêndice B: Resultados numéricos dos questionários. 


\section{CENÁRIO BRASILEIRO DO ARMAZENAMENTO DE SOJA}

\subsection{Armazenagem no Brasil}

No Brasil, os armazéns podem ser classificados em quatro categorias sob o critério da localização, tais como: zonas portuárias, áreas urbanas, áreas rurais externas à fazenda e áreas internas às unidades produtoras, como mostra a Figura 1.

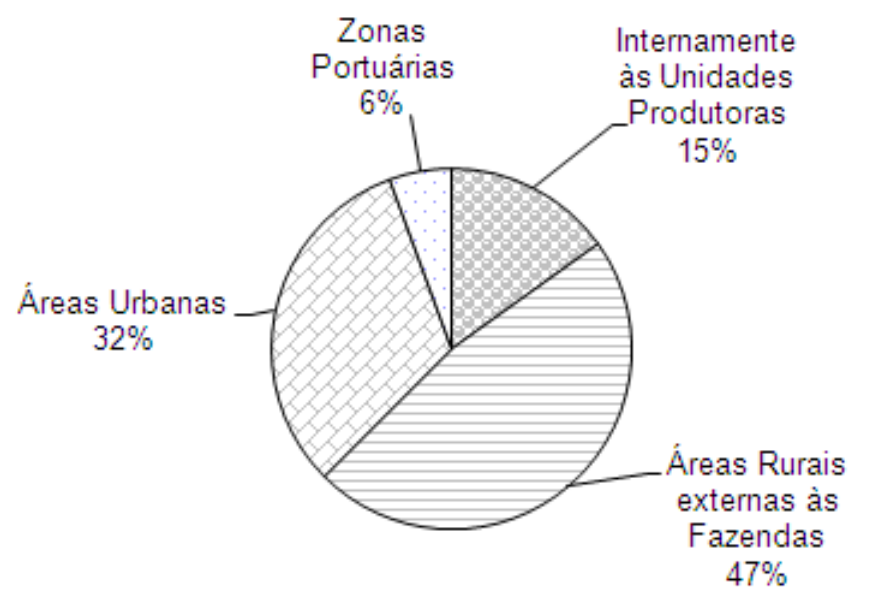

\section{Figura 1 - Composição da armazenagem agrícola no Brasil}

Fonte: Adaptado de Gallardo et al (2010)

Como apenas $15 \%$ dos armazéns encontram-se internamente às unidades produtoras, a capacidade dos produtores de vender seus produtos a melhores preços na época de entressafra é limitada. Se de um lado o armazenamento da produção permite a escolha do melhor momento para a sua comercialização, buscando preços mais atrativos, de outro exige sacrifícios financeiros. A imobilização de recursos pelo investimento em infraestrutura de armazenagem, custos de conservação do produto e abdicação de um possível ganho financeiro com a aplicação dos recursos que seriam conseguidos com a venda desses produtos são exemplos desses sacrifícios (ZANCHET, 2004).

Para analisar o cenário atual de armazenagem no Brasil foram utilizados dados secundários extraídos da base de dados do IBGE (2012), e também, a metodologia aplicada por Oliveira et 
al (2009) para o cálculo de uma possível deficiência ou superavit de capacidade de armazenamento estática e dinâmica para a produção de soja e milho no Brasil.

A capacidade estática é a quantidade de produto que pode ser armazenada na estrutura física do armazém ou silo, enquanto a armazenagem dinâmica é a rotatividade do produto, expressando assim a capacidade de armazenagem em um determinado período de tempo. Segundo Nogueira Junior (2008) e FAO (Fundação da Organização das Nações Unidas para a Alimentação e a Agricultura), pode ser aplicado o fator de rotatividade 1,5, de plena aceitação universal, para cálculo da capacidade dinâmica. Dessa forma o índice de rotatividade utilizado para o cálculo foi de 1,5, ou seja, a capacidade dinâmica é 1,5 vezes a capacidade estática.

Foi analisada a produção de soja e milho no Brasil de 2007 a 2010, separando a quantidade produzida por região. As informações de milho foram utilizadas, pois é o segundo grão mais produzido no Brasil e que concorre com a soja (o grão mais produzido) por armazenagem a granel, objeto de estudo desta dissertação. Em seguida, organizou-se uma listagem onde constam a capacidade útil de armazéns graneleiros e silos, fazendo assim o levantamento da capacidade de armazenagem estática, segundo estimativas do IBGE até o segundo semestre de 2010. Com os dados disponíveis, foi confrontada a quantidade de milho e soja produzidos e a capacidade estática dos armazéns, a fim de descobrir se havia um desvio positivo ou negativo de armazenagem no período de 2007 a 2010, identificando as regiões mais problemáticas. Não foi levada em consideração a capacidade de armazéns convencionais pela dificuldade em se obter os volumes somente destinados a produtos agrícolas para o período 2007 a 2010 e por este concorrer com muitos outros produtos agrícolas. O objetivo é de disponibilizar uma noção de grandeza da situação existente de armazenagem granel no Brasil, objeto de estudo deste trabalho.

\subsubsection{Capacidade Estática}

Utilizando os dados referentes às culturas de soja e milho, observou-se que a capacidade estática de armazenagem a granel em 2007 era de 92 milhões de toneladas para uma produção de 110 milhões de toneladas, mostrando um desvio negativo de 18 milhões de toneladas. No segundo semestre de 2010, esta possível deficiência na capacidade de armazenagem aumentou em 475 mil toneladas. Como pode ser observado na Tabela 4, no período de 4 anos a produção de soja e milho tiveram, respectivamente, um aumento de $19 \%$ e 6\%, enquanto 
que a capacidade estática de armazenagem a granel aumentou apenas $15 \%$. A deficiência na capacidade de armazenagem estática a granel no período analisado aumentou 3\%. A evolução da produção e capacidade no período de 2007 e 2010 pode ser observada na Figura 2.

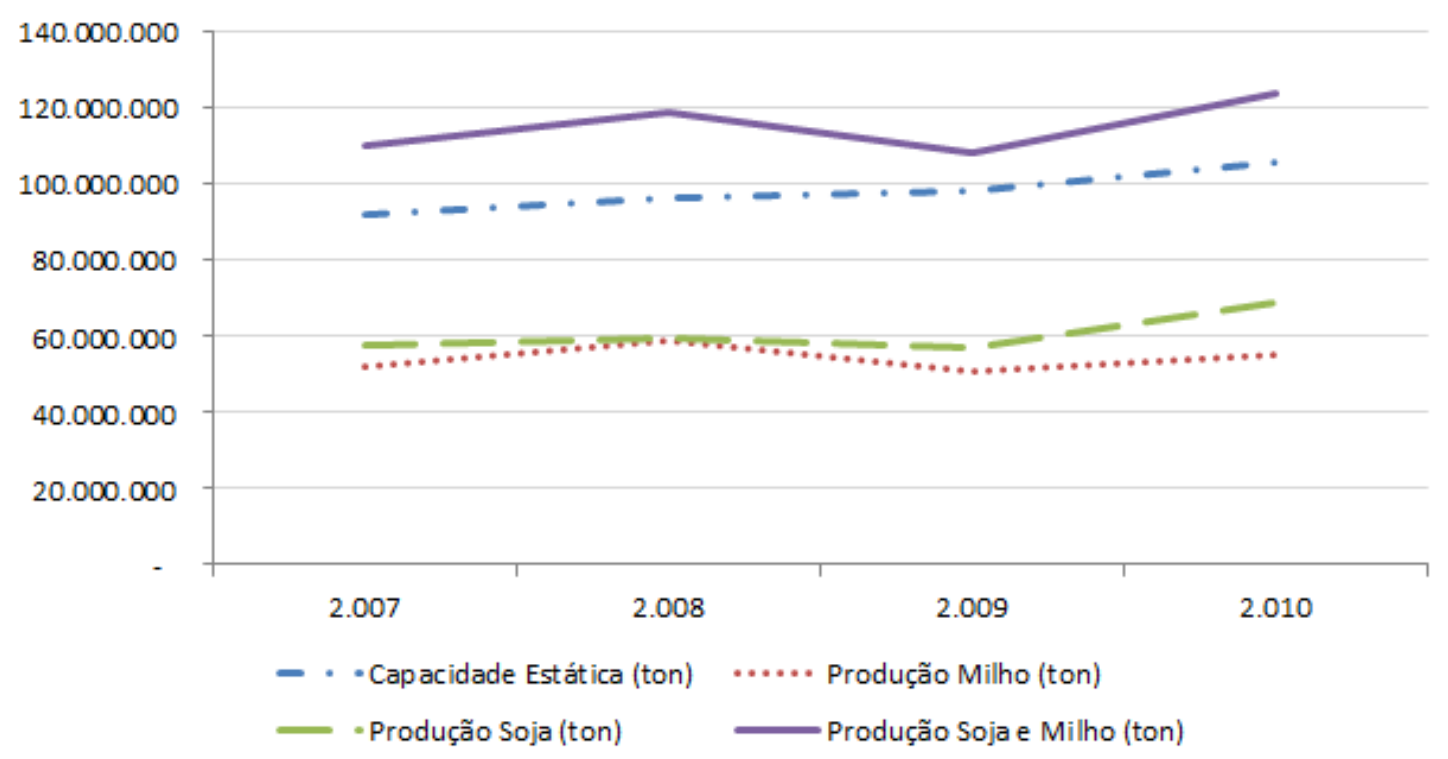

Figura 2 - Evolução da capacidade estática e produção de soja e milho no Brasil

Tabela 3 - Comparação da produção x capacidade estática de armazenagem no Brasil nos anos de 2007 a 2010

\begin{tabular}{|c|c|c|c|c|c|}
\hline & 2007 & 2008 & 2009 & 2010 & $\begin{array}{c}\text { Aumento no } \\
\text { Período } \\
\end{array}$ \\
\hline Capacidade Estática (ton) & 92.026 .246 & 96.600 .269 & 98.389 .927 & 105.732 .688 & $15 \%$ \\
\hline Produção Milho (ton) & 52.112 .217 & 58.933 .347 & 50.719 .822 & 55.394 .801 & $6 \%$ \\
\hline Produção Soja (ton) & 57.857 .172 & 59.833 .105 & 57.345 .382 & 68.756 .343 & $19 \%$ \\
\hline $\begin{array}{l}\text { Produção Soja e Milho } \\
\text { (ton) }\end{array}$ & 109.969.389 & 118.766 .452 & 108.065 .204 & 124.151 .144 & $13 \%$ \\
\hline $\begin{array}{l}\text { Deficiência Estática de } \\
\text { Armazenagem (ton) }\end{array}$ & -17.943 .143 & -22.166 .183 & -9.675 .277 & -18.418 .456 & $3 \%$ \\
\hline
\end{tabular}

Para verificar quais as regiões que apresentam as maiores deficiências, os dados foram abertos por região.

A região Centro-Oeste, além de ser a maior região em produção de milho e soja somados, apresentou a maior deficiência no período de 2007 a 2010. Observou-se que a capacidade estática de armazenagem a granel em 2007 era de 36 milhões de toneladas para uma produção 
de 40 milhões de toneladas, mostrando uma deficiência de armazenagem de 4 milhões de toneladas. No segundo semestre de 2010, a deficiência na capacidade de armazenagem aumentou em 5 milhões de toneladas. Como pode ser observado na Tabela 5 , no período de 4 anos, a produção de soja e milho tiveram, respectivamente, um aumento de $20 \%$ e $25 \%$, enquanto que a capacidade estática de armazenagem a granel aumentou apenas $11 \%$. A deficiência na capacidade de armazenagem estática a granel no período analisado aumentou $144 \%$.

Tabela 4 - Comparação da produção $x$ capacidade estática de armazenagem na região Centro-Oeste nos anos de 2007 a 2010

\begin{tabular}{|c|c|c|c|c|c|}
\hline Centro-Oeste & 2007 & 2008 & 2009 & 2010 & $\begin{array}{c}\text { Aumento no } \\
\text { Período }\end{array}$ \\
\hline Capacidade Estática (ton) & 36.335 .189 & 37.750 .750 & 38.322 .139 & 40.199 .656 & $11 \%$ \\
\hline Produção Milho (ton) & 13.522 .338 & 16.901 .685 & 15.627 .025 & 16.900 .451 & $25 \%$ \\
\hline Produção Soja (ton) & 26.201 .565 & 29.131 .995 & 28.973 .683 & 31.558 .236 & $20 \%$ \\
\hline $\begin{array}{l}\text { Produção Soja e Milho } \\
\text { (ton) }\end{array}$ & 39.723 .903 & 46.033 .680 & 44.600 .708 & 48.458 .687 & $22 \%$ \\
\hline $\begin{array}{l}\text { Deficiência Estática de } \\
\text { Armazenagem (ton) }\end{array}$ & -3.388 .714 & -8.282 .930 & -6.278 .569 & -8.259 .031 & $144 \%$ \\
\hline
\end{tabular}

A região Nordeste foi a que apresentou o maior aumento percentual na produção de milho e soja juntos e apresentou a segunda maior deficiência no período de 2007 a 2010. Observou-se que a capacidade estática de armazenagem a granel em 2007 era de 4 milhões de toneladas para uma produção de 7 milhões de toneladas, mostrando uma deficiência de armazenagem de 3 milhões de toneladas. No segundo semestre de 2010, a deficiência na capacidade de armazenagem aumentou em quase 2 milhões de toneladas. Como pode ser observado na Tabela 6, no período de 4 anos, a produção de soja e milho tiveram, respectivamente, um aumento de $36 \%$ e $32 \%$, enquanto que a capacidade estática de armazenagem a granel aumentou apenas 17\%. A deficiência na capacidade de armazenagem estática a granel no período analisado aumentou $60 \%$. 
Tabela 5 - Comparação da produção $x$ capacidade estática de armazenagem na região Nordeste nos anos de 2007 a 2010

\begin{tabular}{lccccc}
\hline Nordeste & $\mathbf{2 0 0 7}$ & $\mathbf{2 0 0 8}$ & $\mathbf{2 0 0 9}$ & $\mathbf{2 0 1 0}$ & $\begin{array}{c}\text { Aumento no } \\
\text { Período }\end{array}$ \\
\hline Capacidade Estática (ton) & 4.213 .244 & 4.419 .570 & 4.750 .556 & 4.917 .846 & $17 \%$ \\
Produção Milho (ton) & 3.128 .073 & 4.426 .576 & 4.799 .396 & 4.140 .132 & $32 \%$ \\
$\begin{array}{l}\text { Produção Soja (ton) } \\
\begin{array}{l}\text { Produção Soja e Milho } \\
\text { (ton) }\end{array}\end{array}$ & 3.909 .240 & 4.831 .654 & 4.421 .442 & 5.307 .202 & $36 \%$ \\
\hline $\begin{array}{l}\text { Deficiência Estática de } \\
\text { Armazenagem (ton) }\end{array}$ & -2.824 .069 & -4.838 .660 & -4.470 .282 & -4.529 .488 & $60 \%$ \\
\hline
\end{tabular}

A região Sudeste foi a que apresentou o aumento em capacidade estática superior ao aumento na produção de milho e soja juntas, mas ainda assim, apresentou deficiência no período de 2007 a 2010. Observou-se que a capacidade estática de armazenagem a granel em 2007 era de 10 milhões de toneladas para uma produção de 14 milhões de toneladas, mostrando uma deficiência de armazenagem de quase 4 milhões de toneladas. No segundo semestre de 2010, a deficiência na capacidade de armazenagem diminuiu quase 1 milhão de toneladas. Como pode ser observado na Tabela 7 , no período de 4 anos, a produção de soja e milho tiveram, respectivamente, um aumento de $18 \%$ e $-2 \%$, enquanto que a capacidade estática de armazenagem a granel aumentou $17 \%$. A deficiência na capacidade de armazenagem estática a granel no período analisado reduziu em $35 \%$.

Tabela 6 - Comparação da produção $x$ capacidade estática de armazenagem na região Sudeste nos anos de 2007 a 2010

\begin{tabular}{lccccc}
\hline Sudeste & $\mathbf{2 0 0 7}$ & $\mathbf{2 0 0 8}$ & $\mathbf{2 0 0 9}$ & $\mathbf{2 0 1 0}$ & $\begin{array}{c}\text { Aumento no } \\
\text { Período }\end{array}$ \\
\hline Capacidade Estática (ton) & 10.375 .502 & 11.022 .078 & 11.349 .151 & 12.141 .119 & $17 \%$ \\
Produção Milho (ton) & 10.371 .122 & 11.406 .652 & 10.326 .766 & 10.199 .656 & $-2 \%$ \\
$\begin{array}{l}\text { Produção Soja (ton) } \\
\begin{array}{l}\text { Produção Soja e Milho } \\
\text { (ton) }\end{array}\end{array}$ & 14.661 .829 & 4.012 .458 & 4.078 .536 & 4.315 .398 & $18 \%$ \\
\hline $\begin{array}{l}\text { Deficiência Estática de } \\
\text { Armazenagem (ton) }\end{array}$ & -3.657 .449 & -4.397 .032 & -3.056 .151 & -2.373 .935 & $-35 \%$ \\
\hline
\end{tabular}

A região Sul é a segunda maior em produção de soja e milho juntos e é a região com a maior capacidade estática nacional, mas ainda assim, apresentou deficiência estática no período de 
2007 a 2010. Observou-se que a capacidade estática de armazenagem a granel em 2007 era de 40 milhões de toneladas para uma produção de 47 milhões de toneladas, mostrando uma deficiência de armazenagem de quase 7 milhões de toneladas. No segundo semestre de 2010, a deficiência na capacidade de armazenagem diminuiu em 6 milhões de toneladas. Como pode ser observado na Tabela 8 , no período de 4 anos, a produção de soja e milho tiveram, respectivamente, um aumento de $13 \%$ e $-5 \%$, enquanto que a capacidade estática de armazenagem a granel aumentou 18\%. A deficiência na capacidade de armazenagem estática a granel no período analisado reduziu em $75 \%$.

Tabela 7 - Comparação da produção x capacidade estática de armazenagem na região Sul nos anos de 2007 a 2010

\begin{tabular}{lccccc}
\hline Sul & $\mathbf{2 0 0 7}$ & $\mathbf{2 0 0 8}$ & $\mathbf{2 0 0 9}$ & $\mathbf{2 0 1 0}$ & $\begin{array}{c}\text { Aumento no } \\
\text { Período }\end{array}$ \\
\hline Capacidade Estática (ton) & 39.824 .052 & 42.080 .467 & 42.831 .191 & 47.056 .299 & $18 \%$ \\
& 24.020 .568 & 24.934 .542 & 18.693 .066 & 22.854 .811 & $-5 \%$ \\
Produção Milho (ton) & 22.917 .251 & 20.426 .868 & 18.428 .304 & 25.950 .387 & $13 \%$ \\
$\begin{array}{l}\text { Produção Soja (ton) } \\
\begin{array}{l}\text { Produção Soja e Milho } \\
\text { (ton) }\end{array}\end{array}$ & 46.937 .819 & 45.361 .410 & 37.121 .370 & 48.805 .198 & $4 \%$ \\
\hline $\begin{array}{l}\text { Deficiência Estática de } \\
\text { Armazenagem (ton) }\end{array}$ & -7.113 .767 & -3.280 .943 & 5.709 .821 & -1.748 .899 & $-75 \%$ \\
\hline
\end{tabular}

A região Norte foi a com o maior aumento percentual na produção de soja, 39\% no período de 2007 a 2010. Observou-se que a capacidade estática de armazenagem a granel em 2007 era de 1,3 milhão de toneladas para uma produção de 2,2 milhões de toneladas, mostrando uma deficiência de armazenagem de quase 1,0 milhão de toneladas, ou 43\%. No segundo semestre de 2010, a deficiência na capacidade de armazenagem aumentou em 548 mil toneladas. Como pode ser observada na Tabela 9, no período de quatro anos, a produção de soja e milho tiveram, respectivamente, um aumento de $39 \%$ e $21 \%$, enquanto que a capacidade estática de armazenagem a granel aumentou $11 \%$. A deficiência na capacidade de armazenagem estática a granel no período analisado aumentou em $57 \%$. 
Tabela 8 - Comparação da produção x capacidade estática de armazenagem na região Norte nos anos de 2007 a 2010

\begin{tabular}{|c|c|c|c|c|c|}
\hline Norte & 2007 & 2008 & 2009 & 2010 & $\begin{array}{c}\text { Aumento no } \\
\text { Período }\end{array}$ \\
\hline Capacidade Estática (ton) & 1.278 .259 & 1.327 .404 & 1.136 .890 & 1.417 .768 & $11 \%$ \\
\hline Produção Milho (ton) & 1.070 .116 & 1.263 .892 & 1.273 .569 & 1.299 .751 & $21 \%$ \\
\hline Produção Soja (ton) & 1.167.287 & 1.430 .130 & 1.443 .417 & 1.625 .120 & $39 \%$ \\
\hline $\begin{array}{l}\text { Produção Soja e Milho } \\
\text { (ton) }\end{array}$ & 2.237 .403 & 2.694 .022 & 2.716 .986 & 2.924 .871 & $31 \%$ \\
\hline $\begin{array}{l}\text { Deficiência Estática de } \\
\text { Armazenagem (ton) }\end{array}$ & -959.144 & -1.366 .618 & -1.580 .096 & -1.507 .103 & $57 \%$ \\
\hline
\end{tabular}

Logo, o cenário mostra que em 2010 as regiões que apresentam os maiores deficit e aumento deste deficit são as regiões Centro-Oeste e Nordeste, como mostra a Tabela 10.

Tabela 9 - Resumo da Deficiência ou Superavit de Capacidade Estática de Armazenagem

\begin{tabular}{lccccr}
\hline Região & $\mathbf{2 0 0 7}$ & $\mathbf{2 0 0 8}$ & $\mathbf{2 0 0 9}$ & $\mathbf{2 0 1 0}$ & $\begin{array}{c}\text { Aumento no } \\
\text { Período }\end{array}$ \\
\hline Centro-Oeste & -3.388 .714 & -8.282 .930 & -6.278 .569 & -8.259 .031 & $144 \%$ \\
Nordeste & -2.824 .069 & -4.838 .660 & -4.470 .282 & -4.529 .488 & $60 \%$ \\
Norte & -959.144 & -1.366 .618 & -1.580 .096 & -1.507 .103 & $57 \%$ \\
Sudeste & -3.657 .449 & -4.397 .032 & -3.056 .151 & -2.373 .935 & $-35 \%$ \\
Sul & -7.113 .767 & -3.280 .943 & 5.709 .821 & -1.748 .899 & $-75 \%$ \\
\hline
\end{tabular}

\subsubsection{Capacidade Dinâmica}

Para calcular a capacidade dinâmica a granel foi utilizado o fator de rotatividade de 1,5 multiplicado pela a capacidade estática. Este fator tem plena aceitação universal, de acordo com Nogueira Junior (2008, p.3) e Oliveira et al (2009).

Utilizando os dados referentes a essas duas culturas, o fator de rotatividade de 1,5 e a capacidade estática fornecida por IBGE (2012), observa-se que a capacidade dinâmica apresenta um superavit de 28 milhões de toneladas em 2007 em relação à produção de soja e milho de 110 milhões de toneladas (vide Tabela 11). Este superavit é aumentado em 6,4 
milhões de toneladas, conforme observado em 2010. A evolução da produção e capacidade dinâmica no período de 2007 e 2010 pode ser observada na Figura 3.

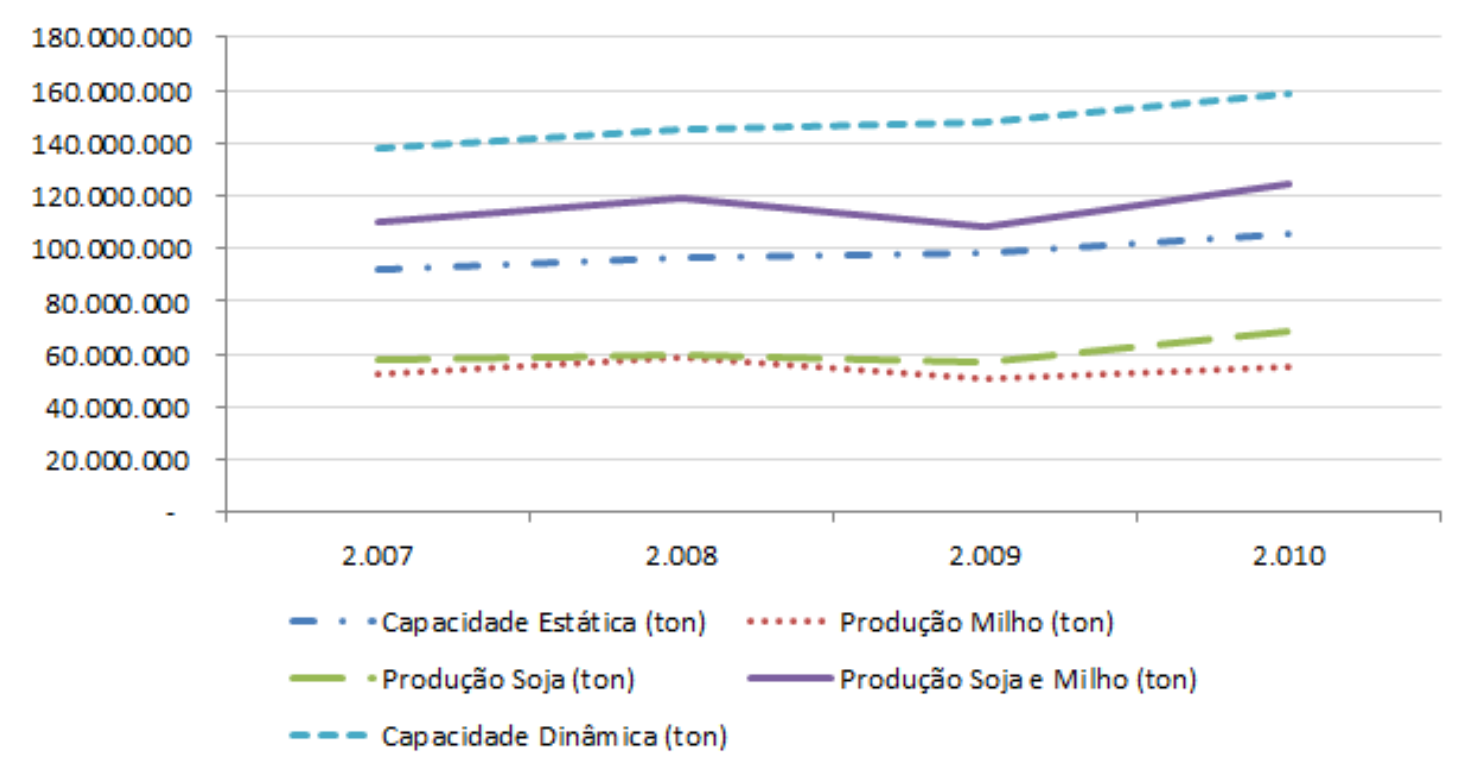

Figura 3 - Evolução da Capacidade Dinâmica e Produção de Soja e Milho no Brasil no período de 2007 a 2010

Tabela 10 - Comparação da produção $x$ capacidade dinâmica de armazenagem no Brasil nos anos de 2007 a 2010

\begin{tabular}{lccccc}
\hline Brasil & $\mathbf{2 0 0 7}$ & $\mathbf{2 0 0 8}$ & $\mathbf{2 0 0 9}$ & $\mathbf{2 0 1 0}$ & $\begin{array}{c}\text { Aumento no } \\
\text { Período }\end{array}$ \\
\hline $\begin{array}{l}\text { Capacidade Dinâmica } \\
\text { ton) }\end{array}$ & 138.039 .369 & 144.900 .404 & 147.584 .891 & 158.599 .032 & $15 \%$ \\
Produção Milho (ton) & 52.112 .217 & 58.933 .347 & 50.719 .822 & 55.394 .801 & $6 \%$ \\
$\begin{array}{l}\text { Produção Soja (ton) } \\
\begin{array}{l}\text { Produção Soja e Milho } \\
\text { (ton) }\end{array}\end{array}$ & 57.857 .172 & 59.833 .105 & 57.345 .382 & 68.756 .343 & $19 \%$ \\
\hline $\begin{array}{l}\text { Deficiência Dinâmica de } \\
\text { Armazenagem (ton) }\end{array}$ & 28.069 .969 .389 & 118.766 .452 & 108.065 .204 & 124.151 .144 & $13 \%$ \\
\hline
\end{tabular}

Para verificar se existia alguma deficiência em capacidade dinâmica local, os dados foram abertos por região. Pode-se concluir que o comportamento no Brasil como um todo não é observado em todas as regiões, como ocorreu nas do Norte e Nordeste.

A região Nordeste apresentou em 2007 6,3 milhões de capacidade dinâmica de armazenagem a granel para uma produção de 7 milhões de toneladas, mostrando uma deficiência de armazenagem de 0,7 milhão de toneladas. No segundo semestre de 2010, a deficiência na capacidade de armazenagem aumentou em 1,3 milhões de toneladas (vide Tabela 12). 
Tabela 11 - Comparação da produção $x$ capacidade dinâmica de armazenagem na região Nordeste nos anos de 2007 a 2010

\begin{tabular}{lccccc}
\hline Nordeste & $\mathbf{2 0 0 7}$ & $\mathbf{2 0 0 8}$ & $\mathbf{2 0 0 9}$ & $\mathbf{2 0 1 0}$ & $\begin{array}{c}\text { Aumento no } \\
\text { Período }\end{array}$ \\
\hline Capacidade Estática (ton) & 4.213 .244 & 4.419 .570 & 4.750 .556 & 4.917 .846 & $17 \%$ \\
$\begin{array}{l}\text { Capacidade Dinâmica } \\
\text { ton) }\end{array}$ & 6.319 .866 & 6.629 .355 & 7.125 .834 & 7.376 .769 & $17 \%$ \\
$\begin{array}{l}\text { Produção Milho (ton) } \\
\text { Produção Soja (ton) }\end{array}$ & 3.128 .073 & 4.426 .576 & 4.799 .396 & 4.140 .132 & $32 \%$ \\
$\begin{array}{l}\text { Produção Soja e Milho } \\
\text { ton) }\end{array}$ & 7.037 .313 & 9.258 .230 & 9.220 .838 & 9.447 .334 & $34 \%$ \\
$\begin{array}{l}\text { Deficiência Estática de } \\
\text { Armazenagem (ton) }\end{array}$ & -2.824 .069 & -4.838 .660 & -4.470 .282 & -4.529 .488 & $60 \%$ \\
\hline $\begin{array}{l}\text { Deficiência Dinâmica de } \\
\text { Armazenagem (ton) }\end{array}$ & -717.447 & -2.628 .875 & -2.095 .004 & -2.070 .565 & $189 \%$ \\
\hline
\end{tabular}

Mesmo a região Norte tendo o menor volume de produção, sua capacidade dinâmica de armazenagem a granel foi de 1,9 milhões de toneladas para uma produção de 2,2 milhões de toneladas, mostrando uma deficiência de armazenagem de 0,3 milhão de toneladas. No segundo semestre de 2010, a deficiência na capacidade de armazenagem aumentou em quase 0,5 milhões de toneladas (vide Tabela 13).

Tabela 12 - Comparação da produção x capacidade dinâmica de armazenagem na região Norte nos anos de 2007 a 2010

\begin{tabular}{lccccc}
\hline Norte & $\mathbf{2 0 0 7}$ & $\mathbf{2 0 0 8}$ & $\mathbf{2 0 0 9}$ & $\mathbf{2 0 1 0}$ & $\begin{array}{c}\text { Aumento no } \\
\text { Período }\end{array}$ \\
\hline Capacidade Estática (ton) & 1.278 .259 & 1.327 .404 & 1.136 .890 & 1.417 .768 & $11 \%$ \\
$\begin{array}{l}\text { Capacidade Dinâmica } \\
\text { (ton) }\end{array}$ & 1.917 .389 & 1.991 .106 & 1.705 .335 & 2.126 .652 & $11 \%$ \\
$\begin{array}{l}\text { Produção Milho (ton) } \\
\text { Produção Soja (ton) }\end{array}$ & 1.070 .116 & 1.263 .892 & 1.273 .569 & 1.299 .751 & $21 \%$ \\
$\begin{array}{l}\text { Produção Soja e Milho } \\
\text { (ton) }\end{array}$ & 2.237 .403 & 2.694 .022 & 2.716 .986 & 2.924 .871 & $31 \%$ \\
$\begin{array}{l}\text { Deficiência Estática de } \\
\text { Armazenagem (ton) }\end{array}$ & -959.144 & -1.366 .618 & -1.580 .096 & -1.507 .103 & $57 \%$ \\
\hline $\begin{array}{l}\text { Deficiência Dinâmica de } \\
\text { Armazenagem (ton) }\end{array}$ & -320.015 & -702.916 & -1.011 .651 & -798.219 & $149 \%$ \\
\hline
\end{tabular}


A capacidade dinâmica de armazenagem a granel das outras regiões brasileiras encontram-se na Tabela 14. E pode-se concluir que as regiões onde mais necessitam de investimento em armazenagem a granel são as regiões Norte e Nordeste. Porém vale ressaltar que os dados de capacidade estática e dinâmica analisados não são exclusivos para soja e milho, ou seja, este cenário pode ser ainda mais pessimista.

Tabela 13 - Resumo da Deficiência ou Superavit de Capacidade Dinâmica de Armazenagem

\begin{tabular}{lccccr}
\hline Região & $\mathbf{2 0 0 7}$ & $\mathbf{2 0 0 8}$ & $\mathbf{2 0 0 9}$ & $\mathbf{2 0 1 0}$ & $\begin{array}{c}\text { Aumento no } \\
\text { Período }\end{array}$ \\
\hline Centro-Oeste & 14.778 .881 & 10.592 .445 & 12.882 .501 & 11.840 .797 & $-20 \%$ \\
Nordeste & -717.447 & -2.628 .875 & -2.095 .004 & -2.070 .565 & $189 \%$ \\
Norte & -320.015 & -702.916 & -1.011 .651 & -798.219 & $149 \%$ \\
Sudeste & 1.530 .302 & 1.114 .007 & 2.618 .425 & 3.696 .625 & $142 \%$ \\
Sul & 12.798 .259 & 17.759 .291 & 27.125 .417 & 21.779 .251 & $70 \%$ \\
& & & & & \\
\hline
\end{tabular}




\section{REVISÃO DE LITERATURA}

\subsection{A cadeia de soja}

Buainaim et al (2006) descreve a cadeia produtiva da soja que é formada por várias camadas desde os insumos até a distribuição ao consumidor final.

A camada de Insumos é composta pelos produtores de sementes, revenda de máquinas, equipamentos, fertilizantes, corretivos, defensivos agrícolas e combustíveis. Após a produção e colheita do grão, verificam-se o armazenamento da soja em grãos e a indústria de transformação do grão em óleo e farelo, até o consumo final do produto, (Figura 4).

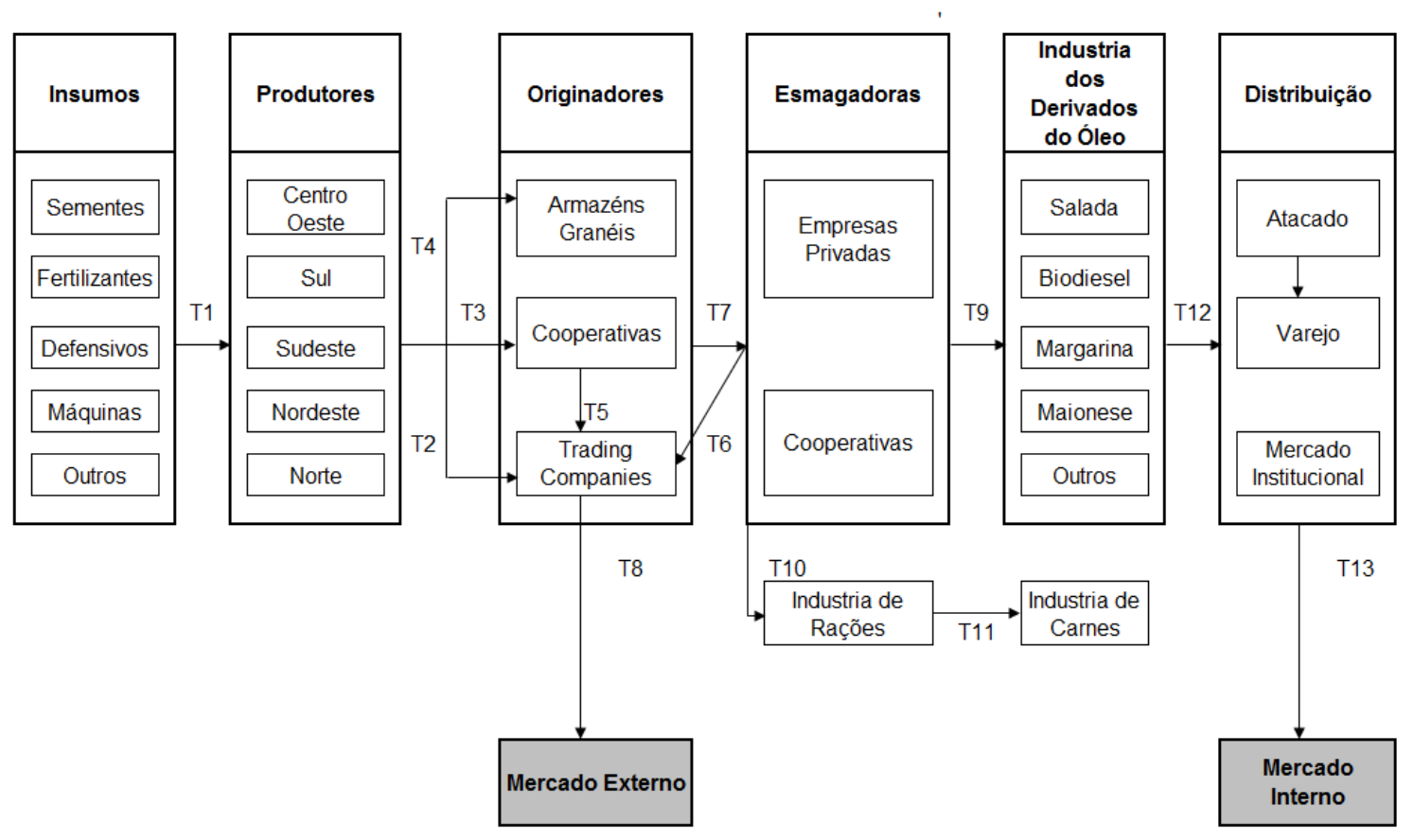

\section{Figura 4 - Cadeia Produtiva da Soja}

Fonte: Adaptado de Buainaim et al (2006) e MAPA ( 2009)

A Produção é composta por médias e grandes propriedades agrícolas que, em geral, atuam segundo as regras do mercado. Este segmento se relaciona com a indústria de insumos, comprando os materiais e equipamentos necessários à produção (fluxo T1). 
A camada "Originadores" composta por tradings, cooperativas e pelos prestadores de serviços de armazenagem se relaciona diretamente com os "Produtores" de soja (fluxos T2, T3, T4), com as "Esmagadoras" (fluxo T7) e com os clientes no "Mercado Externo" (T8). Este segmento compra, armazena e faz a movimentação da produção para a indústria de esmagamento ou para o mercado externo de grãos. No caso das exportações, a comercialização é feita principalmente pelas "tradings". Muitas cooperativas e empresas esmagadoras possuem seus departamentos de comercialização, porém se articulam com as “tradings", para facilitar suas exportações, (T5 e T6).

A indústria Esmagadora (T9) extrai, refina e processa derivados do óleo. Seus principais produtos são o óleo bruto, o óleo refinado e o farelo de soja. A indústria de rações (T10) é outra grande consumidora intermediária de soja. O farelo produzido ou é exportado pelas tradings para o mercado externo ou é adquirido pela indústria de rações para aves, suínos e peixes, passando a ser incorporadas em outras cadeias produtivas, como as de carnes e ovos (T11).

As principais indústrias dos derivados de óleo de soja (T9) são alimentícias que utilizam o óleo para a produção de margarinas, maioneses e molhos de salada e, de bioenergia para a produção de combustíveis de fonte renovável, o óleo biodiesel. Outro segmento dessa cadeia produtiva é a indústria de sabões e cosméticos, que utiliza além do óleo de soja, outros óleos vegetais e gorduras animais em suas formulações industriais.

Para a distribuição (T12) destes produtos, opera uma estrutura de comercialização com atacadistas e varejistas, que se relacionam com os segmentos agroindustriais, para colocar o produto à disposição do consumidor final a fim de suprir as necessidades do Mercado Interno (T13).

\subsubsection{Fatores que Influenciam a Gestão da Cadeia da Soja}

A estratégia competitiva do Brasil na exportação dos produtos do complexo da soja baseia-se principalmente na redução do custo de produção para garantir margem de comercialização. Porém a gestão desta cadeia é complexa por sofrer influência de muitos fatores, tais como: características peculiares da comercialização, oferta e demanda, tributação brasileira, empresas participantes, taxa cambial, capacidade e controle do sistema de armazenagem, entre outros. Esses e outros fatores fazem parte de um conjunto de critérios descritos no item 
3.3.1 para composição da árvore de decisão, porém para o caso específico utilizado por uma trading.

O preço da matéria-prima é formado no mercado internacional, por meio da Bolsa de Chicago, em dólar, havendo uma grande influência em relação à oferta de soja dos três maiores produtores mundiais: Estados Unidos, Brasil e Argentina e à demanda dos principais consumidores: China, Europa e Índia. Como grande parte da produção mundial de grãos se divide entre América do Norte e América do Sul, com épocas de safras distintas, os grupos internacionais buscam estar presentes nas duas regiões (PINAZZA, 2007).

Ojima e Yamakami (2006) representam graficamente estas relações de comercialização, como podem ser vistas na Figura 5, em que $\mathrm{P}$ corresponde ao preço e $\mathrm{Q}$ à quantidade. A quantidade da commodity negociada é igual ao excesso de oferta (ef) na região de exportação, enquanto a quantidade importada é igual ao excesso de demanda (gh) no preço de equilíbrio, assumindo que o custo de transporte é igual a zero entre as duas regiões. Com a existência de tarifas e custos de transporte medidos pela distância vertical entre as curvas de importação demandada e a exportação ofertada (ab), a diferença do preço entre as regiões de importação e exportação é igual às tarifas e custos de transporte. Esses custos e tarifas são compartilhados pelas regiões de exportação e importação, de acordo com as respectivas elasticidades de cada região.

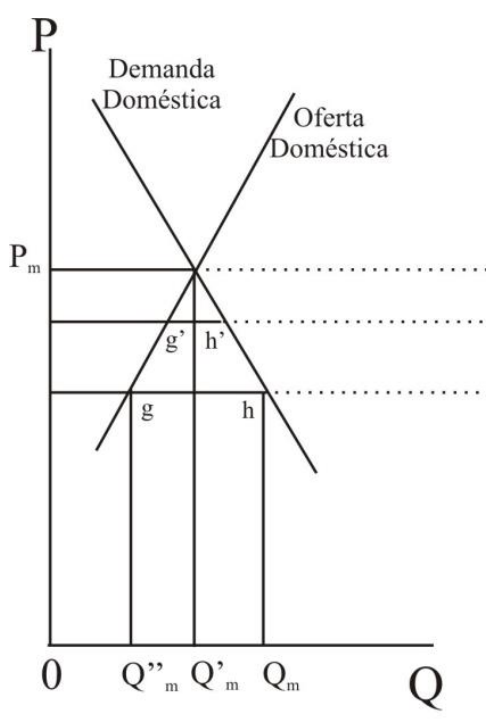

Região Importadora

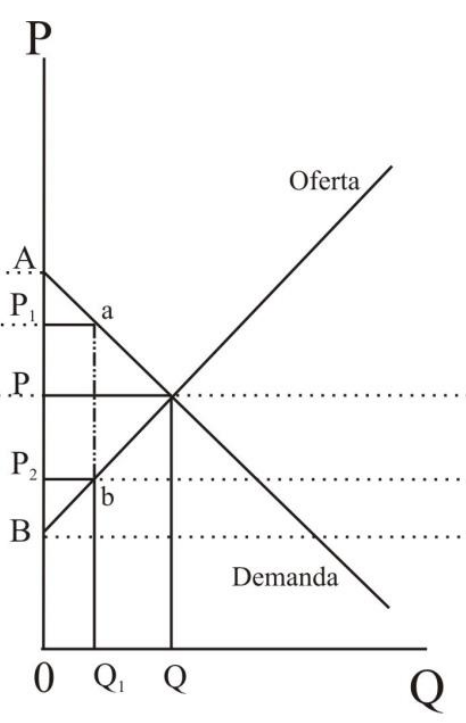

Mercado Internacional

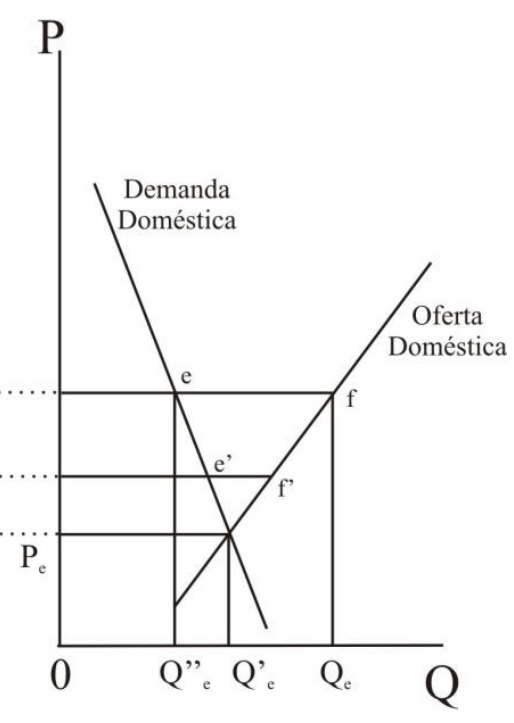

Região Exportadora

Figura 5 - Representação gráfica das relações de comercialização região importadora e região exportadora.

Fonte: Ojima e Yamakami (2006) 
Na Figura 5, as tarifas e custos de transporte (ab) aumentam o preço na região importadora de $\mathrm{P}$ para $\mathrm{P} 1$, assim o aumento do preço pago pela região importadora resulta em decréscimo na quantidade comercializada de Q para Q1. A proporção do diferencial do preço pago pelos produtores das regiões exportadoras (P2) e a incorporação para os consumidores na importação (P1) podem ser calculadas com a função das elasticidades de oferta e demanda, (OJIMA e YAMAKAMI, 2006).

Há uma constante oscilação nos preços dos produtos agrícolas, geralmente obedecendo às pressões da elevada oferta de produtos nos períodos de safra e escassez e nos períodos de entressafra. Como tentativa para se protegerem dessas oscilações, os produtores agrícolas “delegam" ou entregam a sua produção às tradings e agroindústrias numa das seguintes modalidades: 1) mercado spot, consiste na entrega da produção com a imediata efetivação da venda; tudo é esporádico e não há compromisso com futuras transações; 2) contratos a termo ou "produto verde", que consiste no contrato firmado, para a entrega futura da produção com preço previamente fixado; ou seja, o objetivo deste contrato é garantir, por um lado, a entrega do produto pelo produtor e, de outro, o cumprimento do preço pelo agente, conforme estabelecido em contrato; ou ainda, (3) a entrega da produção em depósito com preço a fixar (produção para futura comercialização ou retirada), (AFONSO, 2006).

Em relação à tributação, a Lei Kandir isentou o Imposto sobre Circulação de Mercadorias e Serviços (ICMS) sobre a exportação dos produtos básicos, incluindo a soja em grãos. Desde então, tornou-se mais vantajoso para as indústrias exportarem soja em grão diretamente, a partir dos estados produtores, ao invés de processar a matéria-prima internamente. As características tributárias atuais também fomentam a importação de soja. Para uma indústria instalada no Paraná, é mais vantajoso importar soja do Paraguai, processá-la e, depois, exportar o farelo e o óleo, numa operação de draw back, que percorrer uma distância equivalente e comprar soja, por exemplo, no Mato Grosso do Sul. No caso da compra em outro estado para posterior exportação dos derivados, a indústria enfrenta sérias dificuldades para recuperar os créditos resultantes da incidência do ICMS (PINAZZA, 2007).

A participação das empresas multinacionais na coordenação das atividades do Sistema Agroindustrial (SAG) da soja na economia brasileira torna a sua análise um fator fundamental, tanto para o delineamento de estratégias individuais ou coletivas quanto para a elaboração de políticas públicas que venham a tornar eficiente a coordenação desse sistema produtivo. A linha estratégica predominante é liderança em custos (baseada fortemente em 
economias de escala, busca de redução da capacidade ociosa, logística eficiente, inovação em processos), ao passo que no estágio de derivados predomina a diferenciação de produtos (com forte orientação para segmentação de mercados, promoção/marca e inovação de produtos), confirmando assim, sua "governança". De acordo com dados da Associação Brasileira das Indústrias de Óleos Vegetais (Abiove), as quatro principais esmagadoras de soja atuantes no Brasil são multinacionais e detêm $52,6 \%$ de toda a capacidade de esmagamento instalada (PINAZZA, 2007).

Outro fator que influencia esta cadeia é a questão de armazenagem no Brasil. A partir da década de 1990, com a adoção de uma política de menor intervenção estatal, a capacidade estática de armazenamento permaneceu praticamente estável, enquanto a produção agrícola continuou a crescer. O Estado, principal financiador e armazenador até a década de 1980, começou a se desfazer das suas unidades armazenadoras. Na década de 1990, os maiores investimentos foram realizados pelas tradings, principalmente nos fronts agrícolas, devido ao interesse em ter acesso privilegiado e garantido aos grãos. A participação estatal, que representava a quase totalidade da capacidade de armazenamento existente na década de 1970, reduziu-se a apenas 5\% em 2006, contra $74 \%$ das entidades privadas e $21 \%$ das cooperativas. Sem o controle do sistema de armazenamento as empresas teriam um problema logístico que inviabilizaria a aquisição dos grãos. As formas de financiamento realizadas pelas empresas por meio da CPR (Cédula do Produtor Rural) somente são viabilizadas, na prática, devido à capacidade destas em estocar os grãos (FREDERICO, 2010).

A atual política de armazenagem granel no Brasil vai contra a estratégia ideal de armazenagem sugerida por Ballou (2006), como mostra a Figura 6. Com a baixa participação de armazéns públicos, a iniciativa privada necessita investir e o custo total de armazenagem não consegue ser minimizado. 


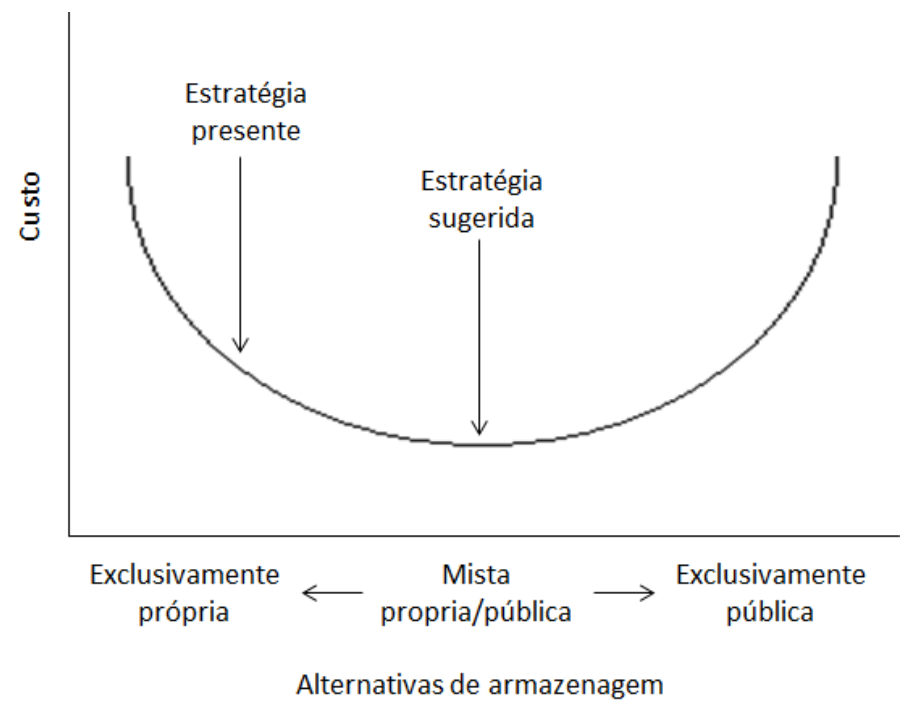

Figura 6- Curva de custo total para estratégia simples e mista de armazenagem.

Fonte: Ojima e Yamakami (2006)

O controle do sistema de armazenamento é tão estratégico que os novos agentes financeiros, que entraram recentemente no comércio mundial de grãos, já estão adquirindo silos nas principais regiões produtoras. Os silos podem oferecer a esses investidores novas maneiras de ganhar dinheiro, porque eles seriam capazes de comprar e vender os grãos de fato, e não apenas os seus derivativos financeiros. Além do ganho com a especulação financeira, a posse do sistema de armazenamento conferiria a esses investidores a possibilidade de manter os estoques para venda futura, auferindo assim maiores lucros do que a venda imediata para atender à demanda corrente. Ou, caso haja preços divergentes em partes diferentes do mundo, estoques podem ser enviados para os mercados mais lucrativos. Os "especuladores" também podem fornecer aos armazenadores o dinheiro necessário para sobreviverem aos mercados de commodities mais voláteis, aguardando melhores preços (FREDERICO, 2010).

\subsubsection{Fluxo da soja}

O fluxo da soja em grão no Brasil (vide Figura 7) tem seu início com a retirada do produto das fazendas por meio do caminhão. A soja tem dois destinos: Mercado Interno com a finalidade de abastecer plantas de esmagamento ou Mercado Externo, onde a soja será exportada in natura. 
A soja destinada ao mercado interno pode seguir direto para o armazém das plantas e/ou para silos e depois para as fábricas. Devido à política fiscal vigente, a incidência de ICMS inviabiliza, na maioria dos casos, movimentações interestaduais, ou seja, é mais vantajoso que a soja seja processada em seu estado de origem. Sendo assim, elimina a etapa de troca de nota fiscal da mercadoria.

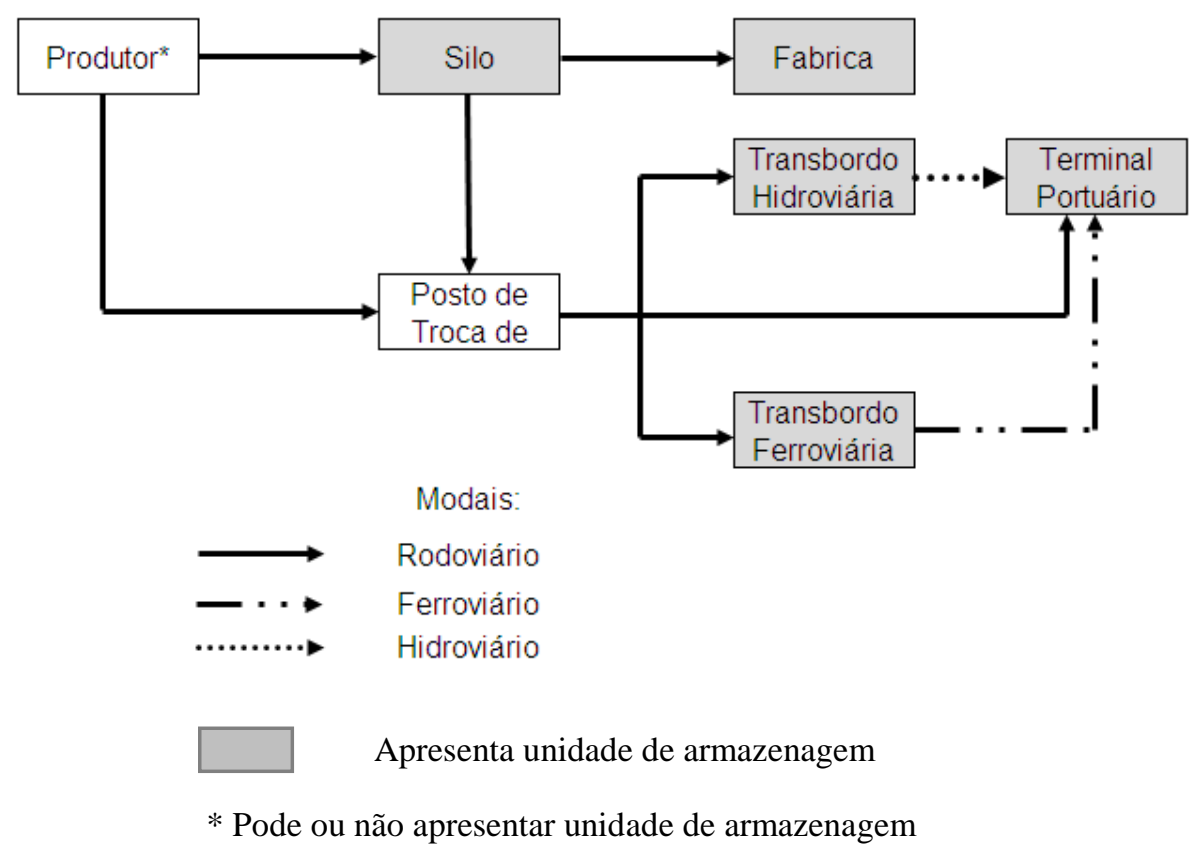

Figura 7- Mapeamento do fluxo da soja em grão

Quando a soja é destinada à exportação, de acordo com a disponibilidade da região, são utilizados transbordos ferroviários e hidroviários que compõem os corredores de escoamento de soja, pois são importantes para diminuir os custos com o transporte até os portos. Como já foi dito, com a isenção do Imposto sobre Circulação de Mercadorias e Serviços (ICMS) sobre a exportação dos produtos básicos, incluindo a soja em grão, tornou-se mais vantajoso para as indústrias exportarem soja em grão diretamente, a partir dos estados produtores, ao invés de processar a matéria-prima internamente. Como estes estados produtores não são os mesmos onde se localizam os principais portos existe a necessidade de passar em Postos de Troca de Nota Fiscal para regulamentação da documentação que acompanha a mercadoria.

A perecibilidade e sazonalidade da produção agrícola demandam um sistema de armazenagem em pontos de distribuição (propriedades rurais, silos, portos e fábricas de esmagamento) para o escoamento da colheita (NOGUEIRA JUNIOR e TSUNECHIRO, 2004). E por isso, a 
armazenagem desempenha um papel fundamental na manutenção do equilíbrio entre oferta e demanda e na continuidade do fluxo ao longo da cadeia.

\subsubsection{Unidade Armazenadora}

\subsubsection{Fluxo da soja na unidade armazenadora}

As unidades armazenadoras para a cadeia da soja geralmente são projetadas para apresentar as seguintes etapas: recepção, limpeza, secagem, armazenagem e expedição.

A disposição dessas estruturas pode-se dar, por exemplo, conforme o leiaute apresentado por Silva (2010) na Figura 7. Cada unidade conta com um silo-pulmão, quatro moegas, um secador, casa de máquinas onde são instaladas as máquinas de pré-limpeza e limpeza, dois silos destinados à condução da operação de seca-aeração e as estruturas para armazenagem e expedição. Complementa a estrutura o setor de recepção que deve contar com um laboratório de análise de grãos e balança rodoviária.

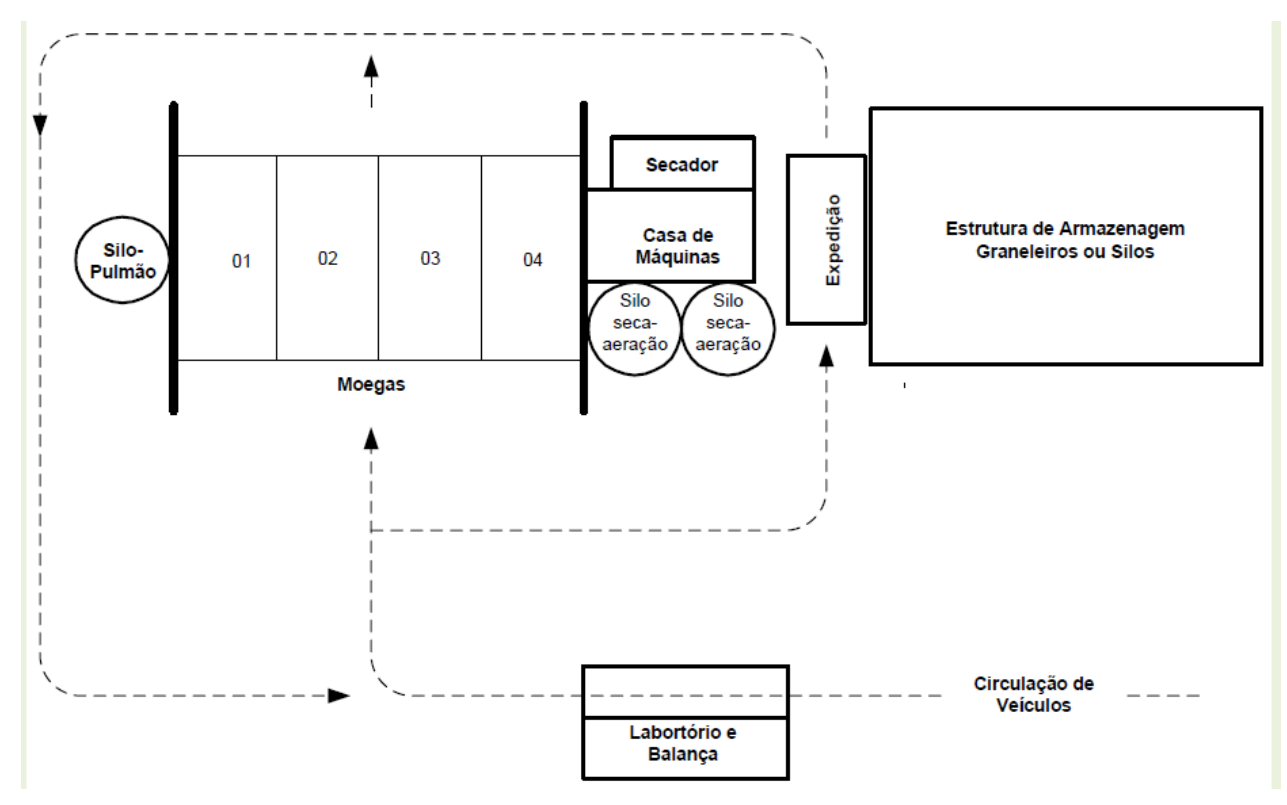

\section{Figura 8 - Esboço de uma unidade armazenadora}

Fonte: Silva (2010)

Dessa forma, esse sistema deve possuir: (i) maquinários: máquinas de pré-limpeza, máquinas de limpeza e secadores; (ii) transportadores de grãos, como: correias transportadoras, elevadores, redlers e transportadores helicoidais ou pneumáticos; e (ii) estruturas para o 
acondicionamento dos grãos durante o pré-processamento, tais como: moegas, silos-pulmão, silos para seca-aeração, silos e/ou graneleiros para armazenagem, e sistema de expedição.

Antes da descarga da matéria prima na moega, é feita uma classificação do produto para determinar os percentuais de umidade, impureza, avariado e esverdeado na amostra para auxiliar os procedimentos nas etapas futuras.

Bragatto e Barrela (2001) resumem muito bem as etapas de preparação e os processos que sofrerão enquanto estiverem armazenados. As etapas que preparam os grãos para um bom armazenamento são:

- pré-limpeza - consiste na retirada de impurezas existentes na massa de grãos;

- secagem convencional - os grãos são submetidos às correntes de ar aquecido por geradores de calor (fornalhas), nos mais diversos tipos de secadores mecânicos, sejam de coluna, intermitentes, concorrentes, contracorrentes, mistos, de fluxo contínuo e estáticos.

A importância da secagem para os produtos agrícolas está aumentando cada vez mais, proporcionalmente ao aumento da produção. A secagem permite um maior retorno econômico e segurança no processamento pós-colheita. Entre outros fatores relevantes, a secagem em altas temperaturas, conforme (HENDERSON \& PERRY (1976); BIAGI et al. (1993); DALBELLO (1995), oferece vantagens como:

- antecipação da colheita "com teor de umidade alto" reduzindo as perdas de campo ocasionadas por intempéries, ação de insetos, pássaros e roedores. A colheita precoce permite também antecipar os trabalhos de cultivo do solo;

- propicia o planejamento da colheita e o emprego mais eficiente de equipamentos e de mão de obra;

- armazenamento por longos períodos sem que ocorra deterioração dos produtos;

- permite a formação de estoques reguladores;

- permite a comercialização do produto em épocas de preços mais vantajosos e também obter uma valorização acima dos preços de mercado, pela oferta de produtos de qualidade. 
Após as etapas de preparação, o produto é transferido para o interior do armazém através de correias transportadoras. Durante o armazenamento temos operações que devem ser realizadas para a adequada conservação do produto, são elas:

- Aeração - movimento forçado de ar através da massa de grãos, objetivando a diminuição e uniformização da temperatura, propiciando condições favoráveis para a conservação da qualidade durante o tempo de armazenamento, pois impede a migração da umidade e a formação de bolsas de calor;

- Transilagem - trata-se da movimentação da massa de grãos, propiciando a uniformização e a diminuição da temperatura;

- Termometria - conjunto de sensores distribuídos simetricamente no interior de um silo ou graneleiro, objetivando a medição periódica da temperatura da massa de grãos;

- Tratamento fitossanitário - objetiva prevenir o aparecimento de insetos ou eliminá-los quando constatados. Como outras operações, o acompanhamento sistemático do produto leva a um controle eficiente ainda no início da infestação;

- Higienização do armazém - evita a formação de focos de infestação de insetos e roedores.

\subsubsection{Tipos de Armazenagem}

A armazenagem de grãos a granel pode ser realizada em armazéns graneleiros, silos metálicos, silos em concreto ou silos bag e armazém convencional, Figura 9. Este último é caracterizado por instalações de piso plano de compartimento único que se destinam à armazenagem de produtos acondicionados em embalagens, como, por exemplo, sacaria. Este tipo não será estudado neste trabalho, pois o tipo de acondicionamento do armazém que será levado em consideração no modelo de decisão é granel. Os demais tipos serão descritos a seguir, Quadro 2. 


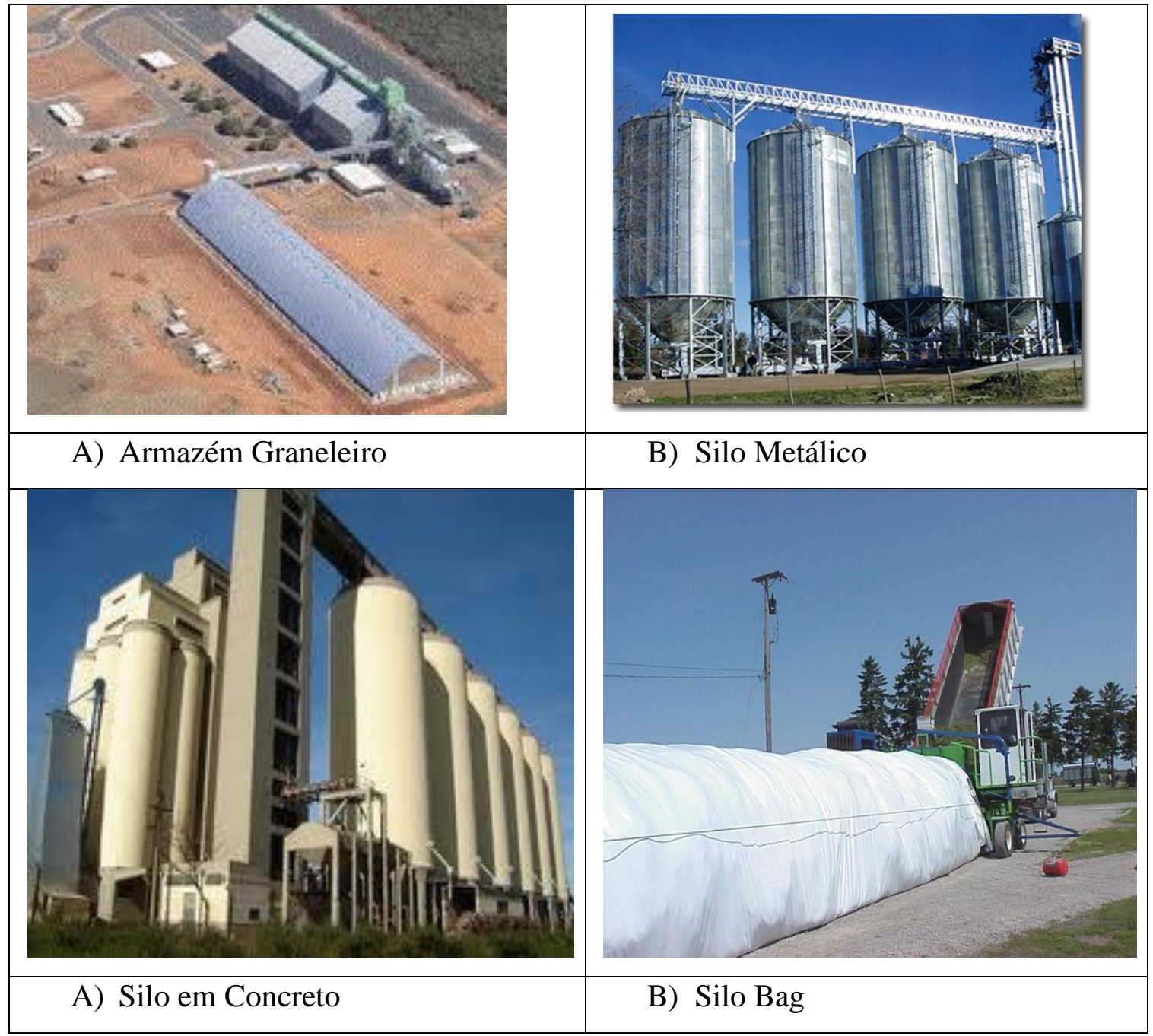

Figura 9 - Tipos de armazenagem

Os armazéns graneleiros são unidades armazenadoras horizontais, de grande capacidade, formada por um ou vários septos, que apresentam predominância do comprimento sobre a largura. Por suas características e simplicidade de construção, na maioria dos casos, representa menor investimento que o silo, para a mesma capacidade de estocagem (DEVILLA, 2004).

Silo é uma unidade armazenadora de grãos com estrutura metálica ou em concreto, caracterizada por um ou mais compartimentos estanques denominados células. Podendo ou não ser equipadas com sistema de aeração, geralmente possuem forma cilíndrica, apresentando condições para a preservação da qualidade do produto, durante longos períodos de armazenagem.

Dependendo da relação que apresentam entre a altura e o diâmetro, os silos podem ser classificados em horizontais e verticais. Os silos horizontais apresentam dimensões da base 
maior que a altura e, comparados com os verticais, exigem menor investimento por tonelada armazenada (DEVILLA, 2004).

As principais características de cada tipo de armazenagem encontram-se no Quadro 2.

\begin{tabular}{|c|c|c|c|c|}
\hline Tipo & $\begin{array}{c}\text { Armazém } \\
\text { Graneleiro } \\
\end{array}$ & Silo Metálico & Silo em Concreto & Silo Bag \\
\hline Material & $\begin{array}{l}\text { Alvenaria ou } \\
\text { Concreto }\end{array}$ & $\begin{array}{c}\text { Chapas lisas ou } \\
\text { corrugadas, de ferro } \\
\text { galvanizado ou alumínio }\end{array}$ & Concreto & Plástico \\
\hline Dimensões & $\begin{array}{l}\text { Comprimento é } \\
\text { maior que a } \\
\text { largura, } \\
\text { classificado como } \\
\text { horizontal. }\end{array}$ & $\begin{array}{c}\text { A relação entre a altura } \\
\text { e o diâmetro, classifica o } \\
\text { silo em horizontal ou } \\
\text { vertical. }\end{array}$ & $\begin{array}{l}\text { A relação entre } \\
\text { a altura e o } \\
\text { diâmetro, } \\
\text { classifica o silo } \\
\text { em horizontal } \\
\text { ou vertical. }\end{array}$ & $\begin{array}{l}\text { Comprimento é } \\
\text { maior que a } \\
\text { largura, } \\
\text { classificado como } \\
\text { horizontal. }\end{array}$ \\
\hline Forma & Retangular & Cilíndrico & Cilíndrico & Cilíndrico \\
\hline $\begin{array}{l}\text { Possui Sistema } \\
\text { de Aeração }\end{array}$ & Pode apresentar & Pode apresentar & Pode apresentar & Não \\
\hline $\begin{array}{l}\text { Capacidade } \\
\text { Estática }\end{array}$ & Grande & Média & Média & Baixa \\
\hline Tipo de Fundo & $\begin{array}{c}\text { Plano, em V ou } \\
\text { em W }\end{array}$ & Em cone & Em cone & Plano \\
\hline $\begin{array}{l}\text { Em relação ao } \\
\text { solo }\end{array}$ & $\begin{array}{c}\text { No nível do solo } \\
\text { ou semienterradas }\end{array}$ & $\begin{array}{c}\text { Elevados ou } \\
\text { semienterrados }\end{array}$ & $\begin{array}{c}\text { Elevados ou } \\
\text { semienterrados }\end{array}$ & $\begin{array}{l}\text { No nível do } \\
\text { solo } \\
\end{array}$ \\
\hline Vantagens & $\begin{array}{l}\text { - baixo custo por } \\
\text { tonelada instalada } \\
\text { - rapidez de } \\
\text { execução } \\
\text { - grande } \\
\text { capacidade }\end{array}$ & $\begin{array}{l}\text { - fundações mais } \\
\text { simples e baratas } \\
\text { - custo por tonelada } \\
\text { inferior ao silo de } \\
\text { concreto } \\
\text { - células de } \\
\text { capacidade média } \\
\text { permitindo maior } \\
\text { flexibilidade } \\
\text { operacional }\end{array}$ & $\begin{array}{c}\text { - menor espaço } \\
\text { ocupado } \\
\text { - paredes espessas, } \\
\text { evitando transmissão } \\
\text { de calor para a massa } \\
\text { de grãos; } \\
\text { - melhor conservação } \\
\text { dos grãos, permitindo } \\
\text { armazenagem por } \\
\text { longo tempo }\end{array}$ & $\begin{array}{l}\text { - baixo custo } \\
\text { por tonelada } \\
\text { instalada; } \\
\text { - flexibilidade } \\
\text { quanto a sua } \\
\text { localização; } \\
\text { - melhor } \\
\text { conservação } \\
\text { dos grãos } \\
\text { devido a } \\
\text { anaerobiose; }\end{array}$ \\
\hline Desvantagens & $\begin{array}{c}\text { - pequena } \\
\text { versatilidade na } \\
\text { movimentação de } \\
\text { grãos } \\
\text { - pequeno } \\
\text { número de células } \\
\text { - grande } \\
\text { possibilidade de } \\
\text { infiltração d'água } \\
\text { - possibilidade de } \\
\text { ocorrer } \\
\text { dificuldade de } \\
\text { aeração } \\
\end{array}$ & $\begin{array}{l}\text { - possível infiltração } \\
\text { de água } \\
\text { - transmissão de } \\
\text { calor ambiente para } \\
\text { dentro da célula, } \\
\text { - maior custo de } \\
\text { instalação que os } \\
\text { graneleiros }\end{array}$ & $\begin{array}{l}\text { - alto custo de } \\
\text { implantação e longo } \\
\text { tempo para construção } \\
\text { - torre de serviço cara } \\
\text { - grande altura de } \\
\text { queda dos grãos, } \\
\text { causando quebra. }\end{array}$ & $\begin{array}{l}\text { - processo } \\
\text { lento de carga } \\
\text { e descarga; } \\
\text { - baixa } \\
\text { capacidade } \\
\text { estática se } \\
\text { comparado os } \\
\text { Tipos. }\end{array}$ \\
\hline
\end{tabular}

Quadro 2 - Tipos de Armazenagem 


\subsection{Método de Análise Multicritério de Apoio à Decisão}

\subsubsection{Influências das Escolas Americanas e Europeia}

Zuffo et al (2010) fazem uma análise temporal da evolução da análise multicriterial e apontam as Escolas que mais contribuíram para o aperfeiçoamento do MCDM. Segundo os autores, a análise multicriterial teve início com o trabalho de Pareto (1896), que examinou um problema de agregação de critérios dentro de um critério simples, definindo o conceito da eficiência entre duas alternativas. Mas destacam que foi somente durante a segunda guerra mundial, com o impulso na pesquisa operacional, que passou a ser estudada para auxiliar a tomada de decisão no cenário militar.

As duas escolas citadas foram a Escola Americana e a Escola Europeia. A primeira ficou conhecida por buscar a otimização das funções objetivo, baseando-se em teoremas e conceitos na busca de uma "solução ótima". O direcionamento das preferências do decisor foi utilizado para distinguir as três técnicas empregadas: 1) técnica que gera o conjunto das soluções nãodominadas - consideram um vetor função objetivo, não considerando as preferências do decisor; 2) técnicas que incorporam preferências do decisor progressivamente que convergem a uma solução final; 3) técnicas que utilizam uma articulação progressiva das preferências, mas de maneira não dirigida, que tem o seu fim com a satisfação da solução pelos seus decisores.

Os principais conceitos da Escola Europeia são: 1) a inexistência de um problema isolado; 2) cada observador vê o problema de forma diferente segundo seu sistema de valores; 3) a elaboração e a estruturação do problema dependerão do observador; 4) os elementos objetivos e os subjetivos não são segregados, pois dentro do processo decisório, eles possuem interconexão; 5) o decisor pode modificar os seus pontos de vista iniciais ao longo do processo de seleção de alternativas à medida que aumenta o seu conhecimento sobre o problema.

Gomes et al (2002) utilizam os principais conceitos dessas duas escolas na classificação da família de algoritmos multicritério:

- Classificação segundo a Escola Americana é baseada na teoria de utilidade multicritério que através de uma função de utilidade busca agregar os valores de cada alternativa sujeita 
(classificada) em cada critério. Isto permite a representação da importância relativa de cada critério, através da 'taxa de substituição' (trade-offs). Esta teoria ainda assume que todos os estados são comparáveis (não existe incomparabilidade); existe transitividade na relação de preferências e de indiferença. Matematicamente, o valor cardinal de uma alternativa ai é formado por um conjunto de valores v1i, v2i,...vni, onde cada vni é o valor assumido pela alternativa ai em cada um dos n critérios. Isto significa que, caso determinado critério/atributo seja considerado pouco importante diante de outros critérios/atributos, ele receberá um peso (valor atribuído) inferior ao peso atribuído àqueles de maior importância.

- Classificação segundo Escola Europeia ou Francesa é baseada nos modelos de subordinação e síntese. Não existe uma função de valor ou utilidade, a comparação é feita entre alternativas discretas em que existe relação de prevalência de síntese que aceita incomparabilidade. As suas principais características são: 1) permite ordenar (pelo menos parcialmente) as alternativas em termos relativos; 2) permite quatro diferentes formas de comparação entre alternativas: preferência sem hesitação, preferência com hesitação, indiferença e incomparabilidade; 3 ) não necessita de criação de uma função de utilidade, utilizando-se de comparações paritárias e gráficos de Kernel para representar a dominância das alternativas; 4) não pressupõe transitividade, pressupõe subordinação e análise paritária.

O presente trabalho é influenciado pela Escola Americana, já que o método MCDA que será aplicado é baseado no valor de multicritérios. A motivação para utilização desta abordagem se deve, principalmente, ao modo de como os critérios que compõem a decisão são medidos. Nesse método, o valor de cada critério é representado através de uma função, o que permite que todos os critérios sejam comparáveis entre si.

\subsubsection{Metodologia Genérica}

O aprofundamento do conhecimento gerado por essas duas escolas, possibilitou uma evolução do MCDM. Este pode ser, genericamente, descrito como um processo que deve conter as seguintes etapas, como sugere Shimizu (2006):

- definir o problema e variáveis relevantes que influenciam a decisão, que pode ser obtido a partir de um mapa cognitivo ou diagrama de influência; 
- estabelecer os objetivos que agreguem valor a decisão por meio da construção de uma árvore de decisão que oriente o processo de tomada de decisão;

- definir e mensurar os atributos a partir de métodos que utilizam função de valor ou utilidade, por exemplo;

- medir os pesos ou ranquear os critérios contidos na árvore de decisão, através de métodos de swing ou comparação de pares, entre outros;

- criar ou selecionar as alternativas possíveis para que os objetivos sejam alcançados;

- avaliar a consistência das alternativas e dos pesos dos critérios que podem ser feitas a partir de análises de sensibilidade.

Belton e Stewart (2002) representam graficamente o processo de MCDA de uma maneira bem completa, como mostra a Figura 10.

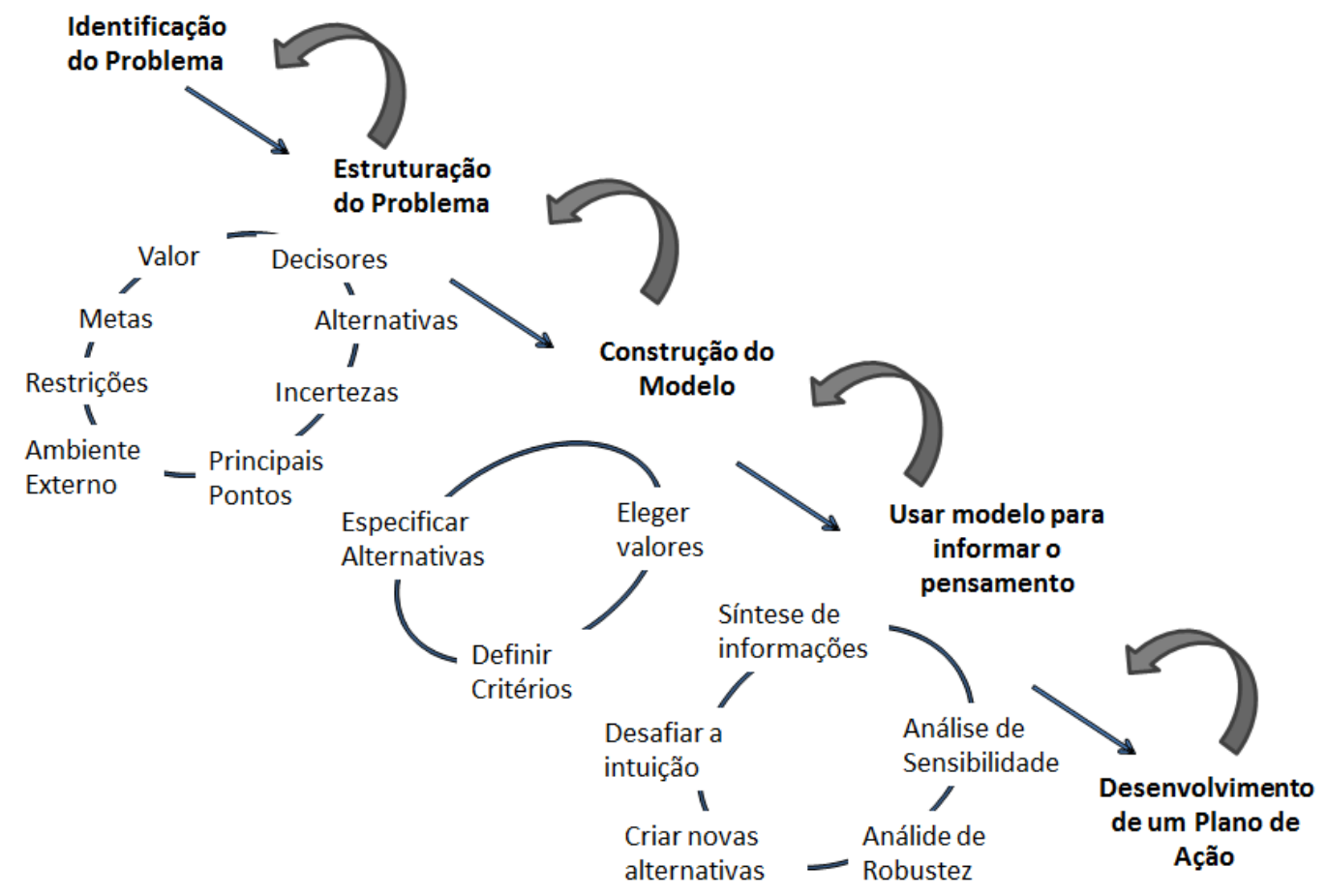

\section{Figura 10 - O processo de MCDA}

Fonte: Belton e Stewart (2002)

Os autores Belton e Stewart (2002) salientam que a abordagem pode ir muito além da estruturação e resolução de um problema. O processo deve ser dinâmico para fomentar um 
ciclo de aprendizado sobre o assunto capaz de criar novas alternativas e promover melhorias em todas as suas etapas. A Estruturação do Problema é a fase de levantamento de dados e informações relevantes do problema e avaliação da sua complexidade. Esta etapa pode ser caracterizada pelo pensamento divergente, mas que com a estruturação das informações permita uma representação gráfica clara do problema para direcionamento dos próximos passos dos decisores. A fase Construção do Modelo define os critérios, alternativas e valores que melhor representam a decisão a ser tomada. Nesta etapa o processo já deve assumir um pensamento convergente. A etapa Aplicação do Modelo consiste em analisar a viabilidade da solução proposta pelo modelo e avaliar sua consistência.

Keeney (1996) sugere que seja mantida, na sequência, a definição de objetivos a serem atingidos, de atributos que medirão quanto dos objetivos foram atendidos e de alternativas que serão os meios para que os objetivos sejam alcançados. $\mathrm{O}$ autor ainda faz um alerta para o foco utilizado em tal processo e propõe que a decisão seja baseada no "Pensamento em Valor" e não no "Pensamento em Alternativas". Explica que para basear-se em "Valor" é necessário torná-lo explícito a partir de um profundo estudo dos objetivos a serem buscados, para depois criar as alternativas que servirão para agregar tais valores.

Outro ponto importante que Keeney (1992) ressalta é a mensuração dos atributos e os classifica em três tipos: natural, proxy e construído. Atributo "Natural" mede diretamente o objetivo. Em geral, é a métrica mais usada por ter um senso comum na sua interpretação. $\mathrm{O}$ atributo 'proxy' apesar de compartilhar qualidades dos atributos naturais, não mede diretamente o objetivo da decisão e, são utilizados quando é difícil selecionar ou medir o 'atributo natural'. $\mathrm{Na}$ impossibilidade ou inexistência de obter um destes dois tipos de atributos, sugere-se desenvolver uma mensuração capaz de medir indiretamente o objetivo, o que é chamado de 'atributo construído'.

A diferenciação dos inúmeros métodos de MCDM encontra-se, geralmente, na etapa de medição das preferências dos atributos. Como será mostrado a seguir nas classificações dos métodos na literatura.

\subsubsection{Classificação dos Métodos de MCDA}

Pardalos et al (1995) propõem a divisão em quatro categorias: 1) Programação Matemática Multiobjetivo; 2) Teoria da Utilidade Multiatributo; 3) Relações de Aproximações 
Hierárquicas; e 4) Métodos baseados na desagregação de Preferências, (ZOPOUNIDIS, 1999; ZUFFO et al, 2010).

A Programação Matemática Multiobjetivo é caracterizada pelo fato das alternativas $\alpha$ serem representadas pelo vetor de variáveis reais $(\mathrm{x} 1, \mathrm{x} 2, \ldots, \mathrm{xl})$. O conjunto $\mathrm{D}$ das soluções viáveis é definido por $(x \in R 1 / A \bullet x \leqslant b, x \geqslant 0)$, onde $A$ é a matriz $m \times 1$ e $b$ é o vetor $m \times 1$. A seleção do vetor $\mathrm{x}$ é baseado nos critérios quantitativos $\mathrm{C} 1, \mathrm{C} 2, \ldots, \mathrm{Cm}$, os quais são contínuos e diferenciáveis em funções de x (linear ou não linear). Os métodos que utilizam esta modelagem são: Modelagem por Metas (goal programming) e Programação de Compromisso (compromise programming).

A Teoria da Utilidade Multiatributo ou MultiAttribute Utility Theory (MAUT) é uma extensão clássica da teoria de utilidade que busca representar as preferências dos tomadores de decisão através de funções de utilidade para cada atributo. Em outras palavras, o princípio é escolher a alternativa que maximize a função de utilidade proposta pelo decisor.

A categoria de Relações de Aproximações Hierárquicas podem ser exemplificadas pelos métodos AHP desenvolvido por Saaty (1980) e ELECTRE (ELimination Et Choix Traduisant la REalité) estudado por Roy and Bouyssou (1993). O método ELECTRE exemplifica bem esta categoria, pois permite avaliar se uma alternativa a ( $\mathrm{a} \in \mathrm{A}$, conjunto discreto) é mais bem ranqueada que a alternativa $b(b \in A)$, mas se e somente se, tem argumento suficiente para confirmar que a é pelo menos melhor ou igual à b. A agregação dos critérios requer a definição de noções de preferência e indiferença, bem como de concordância e discordância.

Os métodos baseados na desagregação de preferências que utilizam de regressões para medir a preferência de um ou mais tomadores de decisão. Esta abordagem é bem parecida com o MAUT, o que os diferenciam está no procedimento de definir a função de utilidade e os pesos.

Já Hajkowicz et al (2000) classificam os métodos MCDM em apenas dois grandes grupos: contínuos e discretos, baseados na natureza das alternativas que serão avaliadas. Os métodos contínuos focam na identificação da quantidade ótima, o que pode variar infinitamente num problema de decisão. Exemplos de métodos contínuos são modelos que se baseiam em técnicas de programação linear, também conhecidos por MultiObjective Linear Programming (MOLP) e goal programming. Os métodos discretos podem ser definidos como técnicas de suporte à decisão com finitas alternativas. Estes métodos se baseiam na definição de objetivos 
e critérios pelos quais as alternativas serão medidas e ranqueadas. Podem ser subdivididos em métodos que mensurem o peso dos critérios ou métodos que realizem um ranking dos critérios para a seleção da alternativa. Estas categorias ainda podem ser divididas em métodos que utilizem dados quantitativos, qualitativos e/ou a combinação destes últimos (ANANDA e HERATH, 2009).

Belton e Stewart (2002) classificam em três categorias: 1) Modelo de Mensuração de Valor, 2) Modelo de Programação de Meta ou Aspiração; 3) Modelo Outranking. Os modelos de Mensuração de Valor permitem que funções de valores sejam construídas para representar o valor de uma opção em relação à outra. Esta escala é determinada inicialmente para cada critério e, depois integrada. Já os métodos de Programação de Meta ou Aspiração são os métodos baseados em programação linear. E, finalmente, os modelos Outranking baseiam-se em comparações paritárias das alternativas.

Comparando as classificações, a proposta por Hajkowicz et al (2000) parece ser mais simplista já que divide em apenas dois grandes grupos baseados apenas na natureza das alternativas e não nas características da metodologia em si. As classificações de Belton e Stewart (2002) e Pardalos (1995) segregam em mais categorias e baseiam-se no modo de medição de preferência dos critérios e alternativas pelos decisores. A única diferença entre estas duas classificações está na subdivisão dos métodos baseados na Teoria de utilidade multiatributo, em desagregação de preferências utilizadas por Pardalos (1995). O Quadro 3 apresenta um resumo das equivalências nas diferentes classificações.

\begin{tabular}{|c|c|c|c|}
\hline $\begin{array}{c}\text { Hajkowicz et al (2000) } \\
\text { classifica em: }\end{array}$ & $\begin{array}{c}\text { Belton e Stewart } \\
(\mathbf{2 0 0 2}) \text { classificam em: }\end{array}$ & $\begin{array}{c}\text { Pardalos (1995) } \\
\text { classifica em: }\end{array}$ & $\begin{array}{c}\text { Exemplo de } \\
\text { Métodos: }\end{array}$ \\
\hline \multirow{2}{*}{ Contínuo } & $\begin{array}{c}\text { Programação de Meta } \\
\text { ou Aspiração }\end{array}$ & $\begin{array}{c}\text { Programação } \\
\text { Matemática } \\
\text { Multiobjetivo }\end{array}$ & $\begin{array}{c}\text { Goal e Compromise } \\
\text { Programming }\end{array}$ \\
\hline \multirow{2}{*}{ Discreto } & Outranking & $\begin{array}{c}\text { Relações de } \\
\text { Aproximações } \\
\text { Hierárquicas }\end{array}$ & $\begin{array}{c}\text { AHP, ELECTRE I, II } \\
\text { e TRI, PROMETHE }\end{array}$ \\
\cline { 2 - 4 } & Mensuração de Valor & $\begin{array}{c}\text { Teoria de Utilidade } \\
\text { Multiatributo }\end{array}$ & MAUT, MAVT \\
\hline
\end{tabular}

Quadro 3 - Resumo das classificações dos métodos de análise de multicritério MCDA

O método MCDA que será aplicado neste presente trabalho é o MAVT que segundo Pardalos (1995), pertence ao grupo Teoria de Utilidade Multiatributo, segundo Belton e Stewart 
(2002), pertence ao Modelo de Mensuração de Valor e, segundo Hajkowicz et al (2000), faz parte do grupo Discreto.

\subsubsection{Análise Bibliométrica}

Para a melhor compreensão da metodologia aplicada foi realizado um estudo bibliométrico utilizando como ponto de partida uma busca na base de dados ISI Web of Knowledge (Web of Science). Esta busca foi realizada utilizando os tópicos "multicriteria decision analisys", a qual resultou em 1719 trabalhos.

A Análise Bibliométrica foi feita para auxiliar na resposta das seguintes perguntas:

- Qual é a frequência de publicação sobre os métodos de MCDA?

- Identificar os métodos MCDA mais utilizados na base pesquisada.

- Quais são as fontes acadêmicas onde se encontram mais artigos sobre MCDA?

Responder essas perguntas ajudará a justificar a relevância acadêmica desta dissertação, verificar alguma tendência e obter um direcionamento de autores e artigos para referenciar a metodologia MCDA e o método MAVT/MAUT.

Para selecionar a base de dados que melhor se adequasse à aplicação neste presente trabalho, foram utilizados somente periódicos nas áreas: "agricultural engineering", "operations research \& management science", "agricultural economics policy", "agricultural multidisciplinary", "transportation" e "transportation Science technology". As áreas relacionadas com agricultura foram selecionadas para obter artigos relacionados com o tema de armazenagem de um produto agrícola. Já as áreas de Transportes foram filtradas, pois armazenagem é um tópico que pode ser encontrado nesta seção. E a área de Pesquisa Operacional foi selecionada devido a metodologia MCDA aplicada neste trabalho ser considerada como uma ramificação da Pesquisa Operacional e onde se encontram o maior número de publicações desta metodologia.

Os resultados obtidos foram 581 artigos nos quais envolveram 121 periódicos e 468 autores. A distribuição temporal das publicações no período de 1974 a 2011 mostra que nos últimos cinco anos ocorreu um aumento acentuado na publicação sobre análise multicriterial de 
decisão, o que justifica a relevância da utilização desta metodologia, como mostra a Figura 11.

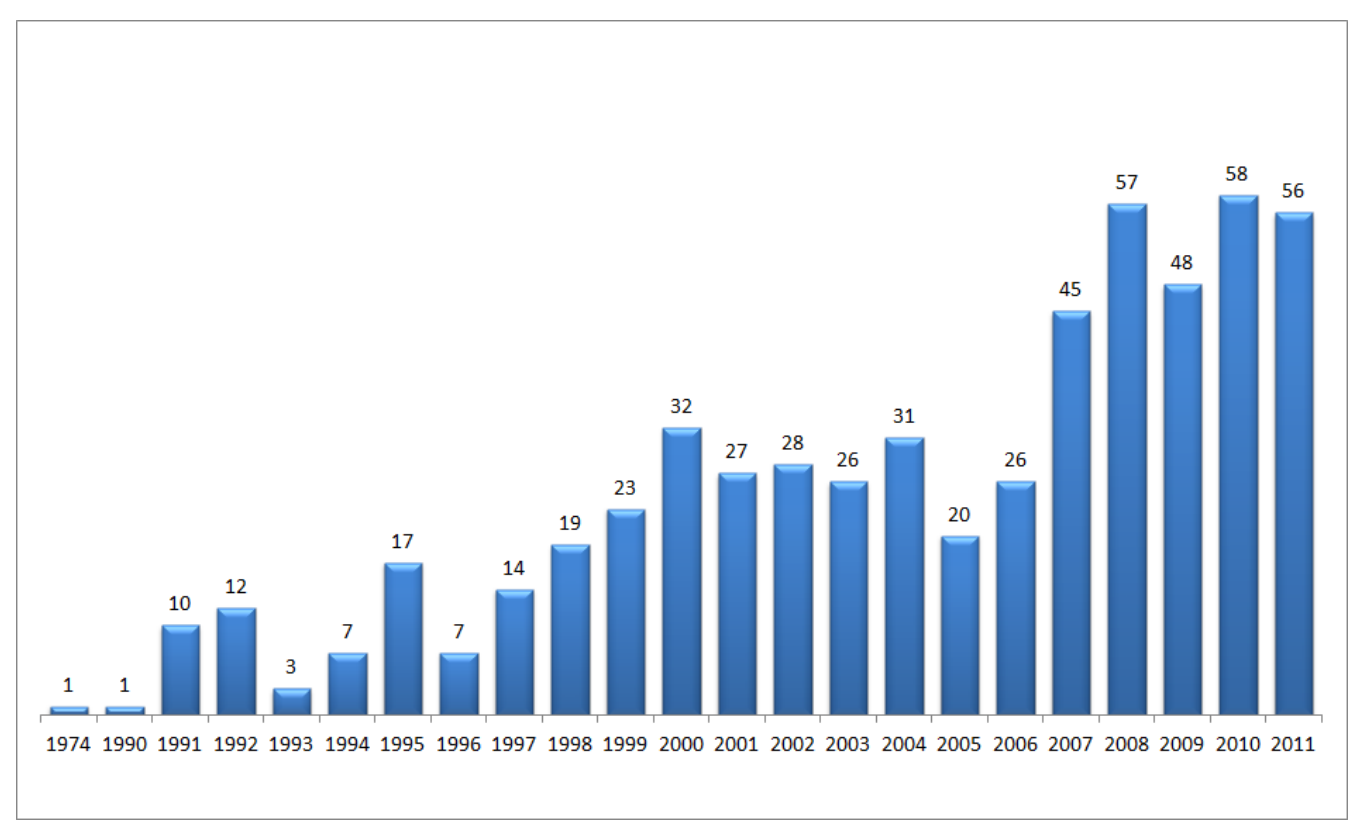

Figura 11 - Publicações de Análise Multicritério de Decisão de 1974 a 2011

A partir da leitura dos 581 resumos, os artigos foram classificados segundo o tipo de pesquisa (aplicada ou conceitual) e o método utilizado. No caso de uma pesquisa aplicada não apresentar o nome do método, este foi classificado como "não especificado". A partir desta classificação foi possível identificar quais os métodos mais utilizados na base de dados em questão (vide Figura 12).

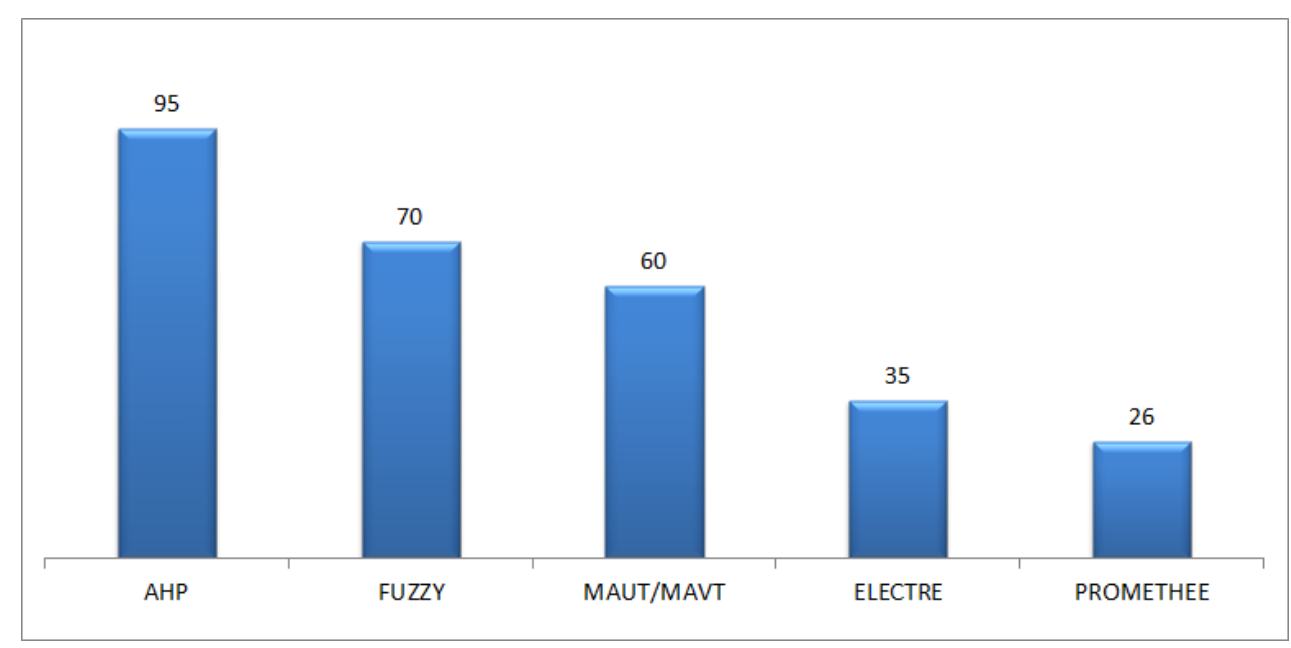

Figura 12- Os 5 principais métodos mais citados na base da análise bibliométrica 
Para melhor compreensão dos métodos mais citados foi construído o Quadro 4 com as principais características de cada método que, geralmente, devem sem observadas em uma análise de multicritério.

\begin{tabular}{|c|c|c|c|c|c|}
\hline Características & AHP & FUZZY & MAUT/MAVT & $\begin{array}{l}\text { ELECTRE I, II e } \\
\text { III }\end{array}$ & PROMETHE \\
\hline Estrutura Básica & $\begin{array}{c}\text { Criar uma } \\
\text { hierarquia e } \\
\text { comparação } \\
\text { entre pares ou } \\
\text { paritária numa } \\
\text { matriz }\end{array}$ & $\begin{array}{c}\text { Traduzir } \\
\text { preferências } \\
\text { linguísticas e } \\
\text { vagas a partir } \\
\text { da teoria de } \\
\text { conjuntos } \\
\text { (Difusa ou } \\
\text { Nebulosa) }\end{array}$ & $\begin{array}{c}\text { Determinar } \\
\text { funções de valor } \\
\text { ou utilidade }\end{array}$ & $\begin{array}{l}\text { I e II: Determinar } \\
\text { índices de } \\
\text { concordância e } \\
\text { discordância; III: } \\
\text { Determinar } \\
\text { índices de } \\
\text { concordância e } \\
\text { discordância com } \\
\text { indiferença e } \\
\text { limites de } \\
\text { preferência. }\end{array}$ & $\begin{array}{c}\text { Criar um } \\
\text { ranking através } \\
\text { de comparações } \\
\text { paritárias dos } \\
\text { critérios e } \\
\text { alternativas e } \\
\text { função de } \\
\text { preferência }\end{array}$ \\
\hline $\begin{array}{l}\text { Pertence a que } \\
\text { grupo segundo } \\
\text { classificação de } \\
\text { Pardalos (1995) }\end{array}$ & $\begin{array}{c}\text { Relações de } \\
\text { Aproximações } \\
\text { Hierarquicas* }\end{array}$ & $\begin{array}{c}\text { Teoria de } \\
\text { Utilidade } \\
\text { Multiatributo }\end{array}$ & $\begin{array}{c}\text { Teoria de } \\
\text { Utilidade } \\
\text { Multiatributo }\end{array}$ & $\begin{array}{c}\text { Relações de } \\
\text { Aproximações } \\
\text { Hierárquicas }\end{array}$ & $\begin{array}{c}\text { Relações de } \\
\text { Aproximações } \\
\text { Hierárquicas }\end{array}$ \\
\hline $\begin{array}{l}\text { Determinação de } \\
\text { Pesos }\end{array}$ & $\begin{array}{l}\text { Comparação } \\
\text { em Pares na } \\
\text { escala de } 1-9\end{array}$ & $\begin{array}{c}\text { Função de } \\
\text { Pertinência na } \\
\text { escala de } 0-1\end{array}$ & $\begin{array}{c}\text { Método Swing e } \\
\text { vetor } \\
\text { normalizado }\end{array}$ & $\begin{array}{l}\text { Não tem um } \\
\text { método } \\
\text { específico. } \\
\text { Baseado no } \\
\text { tomador de } \\
\text { decisão }\end{array}$ & $\begin{array}{l}\text { Função de } \\
\text { Preferência }\end{array}$ \\
\hline $\begin{array}{c}\text { Teste de } \\
\text { Consistência }\end{array}$ & Tem & Não tem & Não tem & $\begin{array}{l}\text { I e II: não tem; } \\
\text { III: tem }\end{array}$ & Não tem \\
\hline $\begin{array}{l}\text { Estrutura do } \\
\text { Problema }\end{array}$ & $\begin{array}{c}\text { Número } \\
\text { reduzido de } \\
\text { alternativas e } \\
\text { critérios, } \\
\text { (quantitativo } \\
\text { ou qualitativo) }\end{array}$ & $\begin{array}{l}\text { Número vasto } \\
\text { de alternativas } \\
\text { e critérios, } \\
\text { (quantitativo } \\
\text { ou qualitativo) }\end{array}$ & $\begin{array}{c}\text { Número } \\
\text { reduzido de } \\
\text { alternativas e } \\
\text { critérios, } \\
\text { (quantitativo ou } \\
\text { qualitativo) }\end{array}$ & $\begin{array}{l}\text { I e II: Vasto } \\
\text { número de } \\
\text { alternativas e } \\
\text { critérios, } \\
\text { (quantitativo ou } \\
\text { qualitativo). } \\
\text { III:Dados } \\
\text { quantitativos e } \\
\text { qualitativos com } \\
\text { uso de lógica } \\
\text { fuzzy }\end{array}$ & $\begin{array}{c}\text { Número } \\
\text { reduzido de } \\
\text { alternativas e } \\
\text { critérios, } \\
\text { (quantitativo ou } \\
\text { qualitativo) }\end{array}$ \\
\hline Precursores & Saaty (1980) & Zadeh (1965) & $\begin{array}{c}\text { Keeney and } \\
\text { Raiffa (1976) e } \\
\text { Zeleny (1982) }\end{array}$ & $\begin{array}{c}\text { Vincke (1992), } \\
\text { Roy e Bouyssou } \\
\text { (1993) e Schärlig } \\
(1996)\end{array}$ & Brans (1982) \\
\hline
\end{tabular}

\section{Quadro 4 - As principais características dos métodos}

Fonte: Adaptado de Özcan (2011) e Shimizu (2006)

O método Analytic Hierarcy Process (AHP) é classificado no grupo de relações aproximadas de hierarquia. Belton e Stewart (2002) identificam algumas similaridades desse método com o MAVT. A principal semelhança está em ambas às abordagens serem baseadas na avaliação de alternativas com base numa função aditiva de preferência. A diferença dos métodos encontra- 
se na mensuração de valor que no caso do AHP são utilizadas comparações paritárias e escalas para todos os julgamentos. $\mathrm{O}$ acentuado número de publicações em AHP pode ser explicado pela transparência, apelo intuitivo de simplicidade e facilidade de utilização. Mas, esses mesmos atributos vêm sendo muito questionados, pois podem ser considerados ao mesmo tempo como sinal de atenção, em relação à sua validade simplista do modelo e o claro entendimento da relação de importância dos critérios.

O método MCDA que será aplicado neste trabalho é o MAVT, que segundo Pardalos (1995) pertence ao grupo Teoria de Utilidade Multiatributo, segunda categoria mais pesquisada.

Os journals com mais publicações sobre o assunto foram European Journal of Operational Reaserch, Omega International Journal of Management Science, Expert Systems with Applications e Journal of Operational Research Society, como mostra a Figura 13.

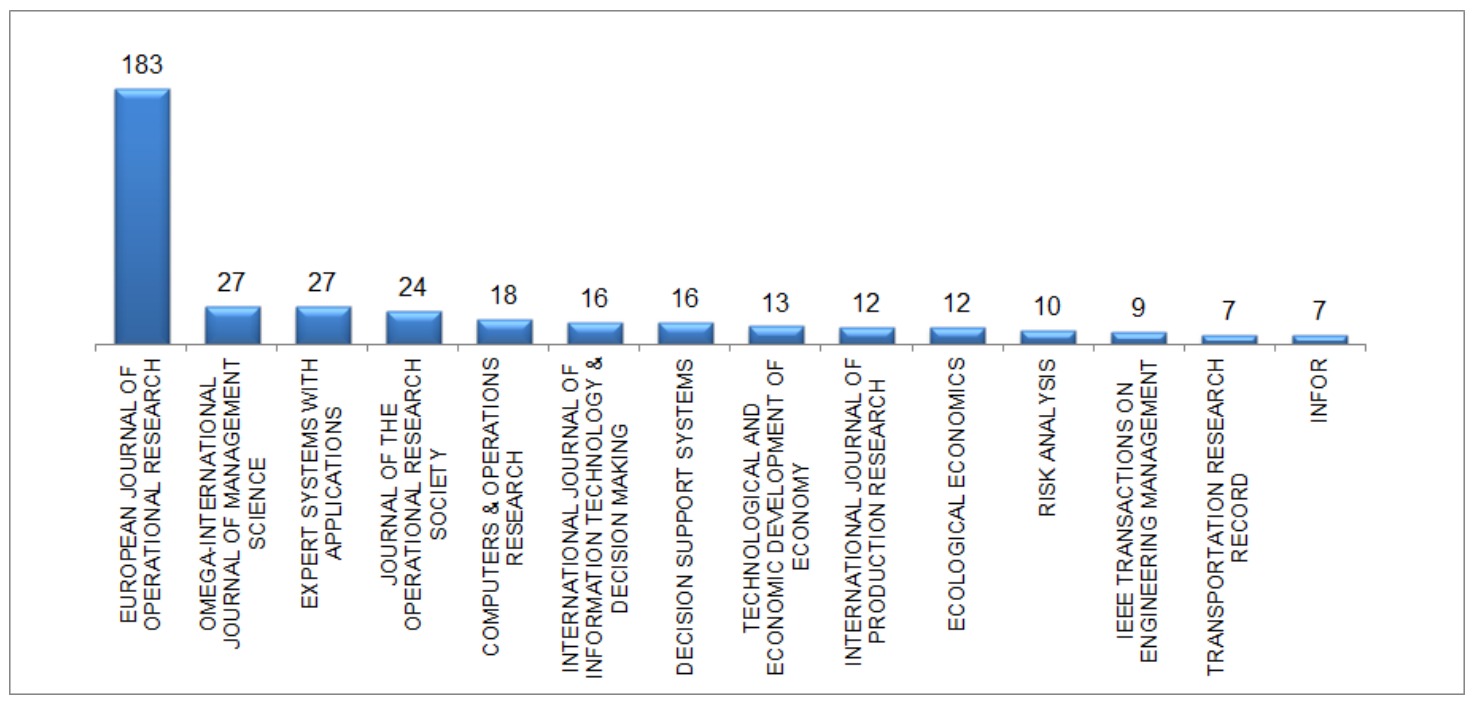

\section{Figura 13 - Principais periódicos que publicam sobre o MCDA.}

O European Journal of Operational Research (EJOR) privilegia as publicações no âmbito do conhecimento e pesquisa de metodologias de Pesquisa Operacional e a prática de tomada de decisão, o que justifica o acentuado número de publicações em análise de multiatributo, já que MCDA é considerada uma ramificação da Pesquisa Operacional e sua aplicação é o de auxiliar processos de tomada de decisão. 


\subsubsection{Teoria de Valor Multiatributo}

O método de MCDM utilizado neste trabalho é o Multi-Attributed Value Theory (MAVT). Belton e Stewart (2002) e Prado (2011) também o chamam de Multi-Attributed Utility Theory (MAUT), derivado da teoria de utilidade aplicado no tratamento de problemas de múltiplos objetivos.

Os métodos de função de valor sintetizam numericamente o desempenho das alternativas (que são medidas em relação cada critério) com a devida reflexão de importância entre os demais critérios segundo as preferências do decisor. Porém, Belton e Stewart (2002) ressaltam que o aprendizado e o entendimento que resultam do engajamento dos decisores em todo processo é de longe a maior contribuição do método.

O modelo pode ser simplificado na função de valor:

$$
V(a)=\sum_{i=1}^{m} w_{i} v_{i}(a)
$$

Onde:

$$
\mathbf{V}(\mathbf{a}) \text { é o valor final da alternativa a ; }
$$

$\mathbf{v}_{\mathbf{i}}$ (a) é o valor que reflete o desempenho da alternativa a em relação ao critério i;

$$
\mathbf{w}_{\mathbf{i}} \text { é o peso que reflete a importância do critério i. }
$$

As etapas principais deste método são: elucitação ou edução da escala de valor $\mathbf{v}_{\mathbf{i}}$ (a) para mensurar o valor da alternativa; elucitação dos pesos dos critérios $\mathbf{w}_{\mathbf{i}}$ e sua normalização; síntese das informações e análises de sensibilidade e robustez para validar o modelo.

O Quadro 5 mostra pesquisas relevantes que utilizaram o método de análise multicritério MAUT. 


\begin{tabular}{|c|c|c|c|c|}
\hline Autor & Ano & Tema & Fonte & Principais Contribuições \\
\hline $\begin{array}{l}\text { Durbach, Ian N.; } \\
\text { Stewart, Theodore } \\
\text { J. }\end{array}$ & 2012 & $\begin{array}{l}\text { A comparison of simplified } \\
\text { value function approaches } \\
\text { for treating uncertainty in } \\
\text { multi-criteria decision } \\
\text { analysis }\end{array}$ & $\begin{array}{l}\text { Omega } \\
\text { International } \\
\text { Journal of } \\
\text { Management } \\
\text { Science }\end{array}$ & $\begin{array}{l}\text { A simplificação de modelos de MAUT se mostrou } \\
\text { eficiente em modelagens que envolvem incerteza no } \\
\text { processo de decisão. Além disso, sugere a utilização } \\
\text { de um pequeno número de critérios. }\end{array}$ \\
\hline $\begin{array}{l}\text { Brito, Anderson } \\
\text { J.; de Almeida, } \\
\text { Adiel Teixeira; } \\
\text { Mota, Caroline M. } \\
\text { M. }\end{array}$ & 2010 & $\begin{array}{l}\text { A multicriteria model for } \\
\text { risk sorting of natural gas } \\
\text { pipelines based on } \\
\text { ELECTRE TRI integrating } \\
\text { Utility Theory }\end{array}$ & $\begin{array}{l}\text { European } \\
\text { Journal of } \\
\text { Operational } \\
\text { Research }\end{array}$ & $\begin{array}{l}\text { Apresenta um modelo de análise multicritério } \\
\text { aplicado num estudo de caso de risco em dutos de } \\
\text { gás natural utilizando uma integração dos métodos } \\
\text { MAUT e ELECTRE TRI. }\end{array}$ \\
\hline $\begin{array}{c}\text { Andre, Francisco } \\
\text { J. }\end{array}$ & 2009 & $\begin{array}{l}\text { Indirect elicitation of non- } \\
\text { linear multi-attribute utility } \\
\text { functions. A dual procedure } \\
\text { combined with DEA }\end{array}$ & $\begin{array}{l}\text { Omega } \\
\text { International } \\
\text { Journal of } \\
\text { Management } \\
\text { Science }\end{array}$ & $\begin{array}{l}\text { Numa simulação do modelo MAUT combinada } \\
\text { com Análise Envoltória de Dados com funções de } \\
\text { valores duais não lineares mostrou que o modelo é } \\
\text { capaz de corrigir parâmetros gerados por erros dos } \\
\text { decisores. }\end{array}$ \\
\hline $\begin{array}{l}\text { Jimenez, Antonio; } \\
\text { Mateos, Alfonso; } \\
\text { Rios-Insua, Sixto }\end{array}$ & 2009 & $\begin{array}{l}\text { Missing consequences in } \\
\text { multiattribute utility theory }\end{array}$ & $\begin{array}{l}\text { Omega } \\
\text { International } \\
\text { Journal of } \\
\text { Management } \\
\text { Science } \\
\end{array}$ & $\begin{array}{l}\text { Apresenta uma aplicação de um modelo MAUT } \\
\text { numa decisão de restauração de ecossistema } \\
\text { aquático com diferentes cenários para lidar de } \\
\text { alguma maneira a incerteza das alternativas. }\end{array}$ \\
\hline $\begin{array}{l}\text { Andre, Francisco } \\
\text { J.; Riesgo, Laura }\end{array}$ & 2007 & $\begin{array}{l}\text { A non-interactive elicitation } \\
\text { method for non-linear } \\
\text { multiattribute utility } \\
\text { functions: Theory and } \\
\text { application to agricultural } \\
\text { economics }\end{array}$ & $\begin{array}{l}\text { European } \\
\text { Journal of } \\
\text { Operational } \\
\text { Research }\end{array}$ & $\begin{array}{l}\text { Discute as dificuldades na modelagem MAUT que } \\
\text { apresentem funções de valores não lineares e } \\
\text { propõe um modelo de elucitação de critérios com } \\
\text { funções de valores não lineares aplicados numa } \\
\text { decisão econômica agrícola. }\end{array}$ \\
\hline $\begin{array}{l}\text { Angilella, S; } \\
\text { Greco, S; } \\
\text { Lamantia, F; } \\
\text { Matarazzo, B }\end{array}$ & 2004 & $\begin{array}{ll}\text { Assessing } & \text { non-additive } \\
\text { utility for multicriteria } \\
\text { decision aid }\end{array}$ & $\begin{array}{l}\text { European } \\
\text { Journal of } \\
\text { Operational } \\
\text { Research }\end{array}$ & $\begin{array}{l}\text { A metodologia apresentada consiste numa função } \\
\text { de utilidade não aditiva utilizando fuzzy integral } \\
\text { (Choquet integral), que permite modelar a } \\
\text { preferência dos tomadores de decisão com uma } \\
\text { certa interação entre os critérios }\end{array}$ \\
\hline $\begin{array}{l}\text { Gomez-Limon, } \\
\text { JA; Arriaza, M; } \\
\text { Riesgo, L }\end{array}$ & 2003 & $\begin{array}{l}\text { An MCDM analysis of } \\
\text { agricultural risk aversion }\end{array}$ & $\begin{array}{l}\text { European } \\
\text { Journal of } \\
\text { Operational } \\
\text { Research }\end{array}$ & $\begin{array}{l}\text { Este trabalho apresenta o método MAUT com } \\
\text { funções de utilidade aditiva, com critérios de } \\
\text { coeficientes relativos e absolutos de aversão ao } \\
\text { risco para um investimento em irrigação na } \\
\text { Espanha. }\end{array}$ \\
\hline
\end{tabular}

\section{Quadro 5 - Publicações dos autores com mais publicações de MAUT na base de dados pesquisada}

Observa-se que a metodologia MAUT pode ser utilizada de forma isolada ou conjuntamente com outros métodos. Embora o tema desta dissertação faça parte de outro domínio de conhecimento, a aplicação do método ainda é recente e segue a mesma linha de Durbach e 
Stewart (2012) e Jimenez, Mateos e Rios-Insua (2009). Isto demonstra a importância e, de certa forma, robustez do método a ser empregado.

\subsection{Métodos e critérios utilizados na logística de armazenagem e distribuição}

O principal objetivo deste trabalho é propor um modelo adequado de análise de decisão multicritério para auxiliar a tomada de decisão de investir numa instalação de armazenagem granel, para soja em grão por um decisor logístico. Os estudos encontrados na literatura privilegiam artigos sobre decisão multicritério de localização de instalações que, com certas adequações, possuem critérios que podem ser utilizados neste trabalho. Para finalizar a composição dos critérios no modelo foram levantados os requisitos que são considerados em um projeto de armazenagem em grão.

Chou (2006) utilizou em sua análise multicritério para uma tomada de decisão de localização de um centro logístico internacional os seguintes critérios: condição do investimento, possibilidade de expansão, disponibilidade de material e recursos humanos. Já para a decisão de localização portuária, Chou (2009) utilizou os seguintes critérios: localização, economia, eficiência, infraestrutura, custos e outras condições. A principal contribuição deste trabalho foi propor um modelo que integrasse o horizonte de curto e longo prazo. A maioria dos artigos no passado levava em consideração apenas o curto prazo e, segundo o autor, esses modelos não podem ser usados para resolver todos os problemas de localização.

Já Korpela et al (2007) propôs um modelo multicriterial na seleção de operadores logísticos com armazenagem baseado numa combinação dos métodos Analytic Hierarch Process (AHP) e Data envelopment analysis (DEA) e utilizou os seguintes critérios: tempo de entrega, qualidade da entrega, quantidade da entrega, urgência na entrega, frequência de entrega, solicitações especiais e capacidade.

Outros autores como Yang e Lee (1997) também utilizaram o método AHP para uma decisão de localização de uma nova instalação ou realocação de uma instalação já existente. Já os critérios e atributos utilizados foram outros, são eles: acesso aos mercados e centros de distribuição (custos de atendimento do mercado, tendências em vendas por regional e potencial de entrar no mercado local pela presença da planta); acesso aos fornecedores (custos de transportes e tendências de novos fornecedores por região); comunidade e acesso ao Governo (custo de vida, cooperação com as indústrias já instaladas na região, satisfação da 
comunidade, presença de igrejas, moradia, escolas e universidades); concorrência (localização e impacto de uma nova instalação); fatores ambientais (conscientização da comunidade e regulamentação pública local e estadual); fatores laborais (média salarial, atuação do sindicato, produtividade, disponibilidade e qualificação); impostos, taxas e financiamentos (impostos sobre a propriedade, incentivos fiscais); transporte (disponibilidade de serviços rodoviário, ferroviário e aéreo) e serviços utilitários (qualidade e preço da água, energia elétrica e gás natural e disponibilidade de polícia, bombeiros e hospitais).

O artigo mais próximo ao tema desta dissertação pertence aos autores Sahnoun et al (2011) que apresentou uma análise multicritério para seleção de potenciais localizações para um complexo agroindustrial. A modelagem MCDA utilizada é o método ELECTRE e os critérios: geológicos (permeabilidade do solo e qualidade da bacia hidrográfica), ambientais (ocupação do solo, zonas de proteção, mercado para subprodutos bioenergéticos), sociais (urbanização), estruturais (proximidade com rodovias, rede de energia elétrica e captação de água) e econômicos (preço da terra, taxa de desemprego e vantagens financeiras).

Demirel et al (2010) propôs uma análise para seleção multicritério de armazém utilizando o método de Choquet integral. Segundo o autor, a principal vantagem da utilização desse método é que se mostrou muito eficiente no tratamento de informações vagas e imprecisas. Os critérios e subcritérios utilizados no modelo proposto foram: custos (custos laborais, custos com transportes, presença de incentivos fiscais, incentivos financeiros e custos de movimentação); recursos humanos (qualificação e disponibilidade de mão de obra); Infraestrutura (presença de intermodais, sistema de telecomunicações e qualidade e confiança nos intermodais existentes); mercado (proximidade dos clientes e fornecedores ou produtores, lead time e capacidade de resposta) e macro ambiente (política pública, leis regulamentadoras da indústria e plano de construção).

O artigo mais recente sobre modelagem multicritério para localização de armazém encontrado foi proposto por Ozcan et al (2011) para uma tomada de decisão no setor de varejo. Os critérios utilizados foram: Preço Unitário, Capacidade de Armazenagem, distância média dos fornecedores e flexibilidade na movimentação. Neste estudo, os autores fazem uma comparação dos métodos AHP, TOPSIS e ELECTRE.

Cambolat et al (2007) propõem um modelo de MCDM de localização de uma nova planta em um dos cinco países propostos baseado na Teoria de Utilidade (Valor) Multiatributo. A 
principal contribuição deste trabalho foi a integração deste método com diagrama de influência e árvore de decisão. Os critérios e subcritérios utilizados foram: Custo Total (Custo do Investimento e custo laborais); Qualidade (qualificação, desempenho do fornecedor, presença de sindicato e comunicação em inglês), Estabilidade (estabilidade política, índices de crescimentos econômicos, estabilidade da moeda, inflação e corrupção); Localização Geográfica e Demográfica (disponibilidade de mão de obra, infraestrutura nacional e mercado regional).

Com foco na proposta de tomada de decisão de um armazém granel de soja em grão, Lacerda Filho et al (2000) e D'Arce (2012) sugerem alguns parâmetros que devem ser verificados para a construção de uma unidade armazenadora, são eles: tipo de produto a serem armazenados, fatores técnicos e econômicos, custo de instalação e de operação, finalidade a que se destina a unidade e localização. Além destes, Devilla (2004) apresenta outros que devem ser levados em consideração, como mostra no Quadro 6.

\begin{tabular}{|c|c|}
\hline Critério & Parâmetros \\
\hline Localização e Dimensionamento & $\begin{array}{c}\text { - Mapa geográfico com perímetro urbano, suburbano e rural; } \\
\text { - Local da construção; } \\
\text { - Vias de Transporte; } \\
\text { - Área da ação do proponente; } \\
\text { - Área de influência da unidade; } \\
\text { - Vias de escoamento da produção; e } \\
\text { - Modalidades de transporte. }\end{array}$ \\
\hline Estudo de Mercado & $\begin{array}{c}\text { - Verificar os agentes de comercialização, suas influências e } \\
\text { suas formas de atuação; } \\
\text { - Caracterizar quanto e qual será a influência que a unidade a } \\
\text { ser implantada exercerá sobre o município; } \\
\text { - Concorrência: quantidades produzidas e os tipos de } \\
\text { produtos; } \\
\text { - Demanda por quantidades a serem processadas por produto } \\
\text { do município e região. }\end{array}$ \\
\hline Infraestrutura e aspectos agrícolas regionais & $\begin{array}{l}\text { - Aspectos agrícolas: clima, solo e culturas plantadas; } \\
\text { - Estabelecer demanda de armazenagem granel por produto; } \\
\text { - Estimar aumento de produção, produtividade e área plantada } \\
\text { num período de pelo menos } 5 \text { anos; } \\
\text { - Analisar os períodos de colheita, estabelecendo o início e o } \\
\text { final de cada safra, com estimativas de quantidade colhida em } \\
\text { cada mês, além de quantificar as perdas, por produto, da } \\
\text { colheita à armazenagem; } \\
\text { - Avaliar as quantidades de produto consumidas nas } \\
\text { indústrias, como sementes, ração, e nas propriedades rurais, } \\
\text { quantificando os estoques existentes e o comportamento da } \\
\text { movimentação de estoques, em relação as outras regiões. }\end{array}$ \\
\hline Aspectos de Engenharia & $\begin{array}{c}\text { - Avaliação das obras civis, eletromecânicas, arquitetônicas, } \\
\text { layout, memoriais descritivos e fluxogramas; } \\
\text { - Avaliação das edificações (topografia, sondagem e } \\
\text { propriedades do solo, além da presença de lençol freático e } \\
\text { plataformas rochosas). }\end{array}$ \\
\hline
\end{tabular}




\begin{tabular}{cc}
\hline Critério & Parâmetros \\
\hline Investimentos Financeiros & $\begin{array}{c}\text { - Investimentos fixos em: construção civil, máquinas e } \\
\text { equipamentos, instalações e montagens e fretes; elaboração de } \\
\text { projetos; e outros. }\end{array}$ \\
$\begin{array}{c}\text { - Quantificação e qualificação das variáveis: encargos } \\
\text { financeiros durante o período de carência, fontes e uso do } \\
\text { cronograma financeiro apresentado ao agente financiador, } \\
\text { rentabilidade e capacidade de pagamento para compor a } \\
\text { análise de retorno financeiro. }\end{array}$ \\
$\begin{array}{c}\text { Por ser de suma importância para o desempenho administrativo } \\
\text { e produtividade da unidade devem ser observados os seguintes } \\
\text { parâmetros: }\end{array}$ \\
Layout e Eficiência Operacional \\
- capacidade estática e dinâmica, \\
produção (ferroviário, rodoviário, pluvial ou marítimo), \\
- linhas de processamento (recepção, pré-limpeza, secagem, \\
limpeza, seleção. Classificação, embalagem e expurgo); \\
- sobrecarga e ociosidade do sistema.
\end{tabular}

\section{Quadro 6 - Principais parâmetros para seleção de um projeto de armazenagem granel para soja}

D’Arce (2012) e Devilla (2004) agruparam os principais critérios para um processo de tomada de decisão de armazenagem de soja em grão. Ao comparar estes critérios específicos de armazenagem granel com alguns dos critérios utilizados em análise multicritério de localização de instalações (vide Quadro 4), pode-se observar muitas similaridades, o que justifica a pertinência e aplicabilidades desses critérios na composição da árvore de decisão deste trabalho.

\begin{tabular}{|c|c|c|c|c|c|c|c|c|}
\hline $\begin{array}{l}\text { Critérios/ } \\
\text { Autor }\end{array}$ & $\begin{array}{c}\text { Yang } \\
\text { e Lee } \\
\text { (1997) }\end{array}$ & $\begin{array}{l}\text { Chou } \\
(2006 \\
\text { e } \\
2009)\end{array}$ & $\begin{array}{c}\text { Korpela } \\
\text { et al } \\
(2007)\end{array}$ & $\begin{array}{c}\text { Demirel } \\
\text { et al } \\
(2010)\end{array}$ & $\begin{array}{c}\text { Sahnoun } \\
\text { et al } \\
(2011)\end{array}$ & $\begin{array}{c}\text { Ozcan } \\
\text { et al } \\
(2011)\end{array}$ & $\begin{array}{c}\text { Canbolat } \\
\text { et al (2007) }\end{array}$ & $\begin{array}{c}\text { Número } \\
\text { de } \\
\text { Repetições }\end{array}$ \\
\hline $\begin{array}{l}\text { Condição de } \\
\text { Investimento }\end{array}$ & & $\mathrm{X}$ & & & & & $\mathrm{x}$ & 2 \\
\hline $\begin{array}{l}\text { Recursos } \\
\text { Humanos }\end{array}$ & $\mathrm{X}$ & $\mathrm{X}$ & & $\mathrm{X}$ & $\mathrm{X}$ & & $\mathrm{x}$ & 5 \\
\hline Economia & & $\mathrm{x}$ & & & $\mathrm{x}$ & & $\mathrm{x}$ & 3 \\
\hline Localização & $\mathrm{x}$ & $\mathrm{x}$ & $\mathrm{x}$ & $\mathrm{X}$ & $\mathrm{x}$ & $\mathrm{X}$ & $\mathrm{x}$ & 7 \\
\hline Eficiência & & $\mathrm{x}$ & & & & & & 1 \\
\hline Custos & $\mathrm{x}$ & $\mathrm{x}$ & & $\mathrm{x}$ & & $\mathrm{x}$ & $\mathrm{x}$ & 5 \\
\hline Capacidade & & & $\mathrm{x}$ & & & $\mathrm{x}$ & & 3 \\
\hline $\begin{array}{l}\text { Acesso ao } \\
\text { Mercado }\end{array}$ & $\mathrm{X}$ & & & $\mathrm{X}$ & & & $\mathrm{x}$ & 3 \\
\hline $\begin{array}{c}\text { Acesso aos } \\
\text { Fornecedores }\end{array}$ & $\mathrm{X}$ & & & & & & & 1 \\
\hline Concorrência & $\mathrm{x}$ & & & & & & & 1 \\
\hline Fatores Sociais & $\mathrm{X}$ & & & $\mathrm{X}$ & $\mathrm{X}$ & & & 3 \\
\hline
\end{tabular}




\begin{tabular}{|c|c|c|c|c|c|c|c|c|}
\hline $\begin{array}{l}\text { Critérios/ } \\
\text { Autor }\end{array}$ & $\begin{array}{c}\text { Yang } \\
\text { e Lee } \\
(1997)\end{array}$ & $\begin{array}{l}\text { Chou } \\
(2006 \\
\text { e } \\
2009) \\
\end{array}$ & $\begin{array}{c}\text { Korpela } \\
\text { et al } \\
(2007)\end{array}$ & $\begin{array}{c}\text { Demirel } \\
\text { et al } \\
(2010)\end{array}$ & $\begin{array}{c}\text { Sahnoun } \\
\text { et al } \\
(2011)\end{array}$ & $\begin{array}{l}\text { Ozcan } \\
\text { et al } \\
(2011)\end{array}$ & $\begin{array}{c}\text { Canbolat } \\
\text { et al (2007) }\end{array}$ & $\begin{array}{c}\text { Número } \\
\text { de } \\
\text { Repetições }\end{array}$ \\
\hline $\begin{array}{l}\text { Acesso ao } \\
\text { Governo }\end{array}$ & $\mathrm{X}$ & & & $\mathrm{X}$ & & & & 2 \\
\hline $\begin{array}{c}\text { Fatores } \\
\text { Ambientais }\end{array}$ & $\mathrm{X}$ & & & & $\mathrm{X}$ & & & 2 \\
\hline $\begin{array}{l}\text { Incentivos } \\
\text { Fiscais }\end{array}$ & $\mathrm{X}$ & & & $\mathrm{X}$ & $\mathrm{X}$ & & & 3 \\
\hline $\begin{array}{l}\text { Infraestrutura } \\
\text { da Região }\end{array}$ & $\mathrm{X}$ & $\mathrm{X}$ & & $\mathrm{X}$ & $\mathrm{X}$ & & $\mathrm{x}$ & 5 \\
\hline $\begin{array}{c}\text { Modais } \\
\text { disponíveis }\end{array}$ & $\mathrm{X}$ & & & $\mathrm{X}$ & $\mathrm{X}$ & $\mathrm{X}$ & $\mathrm{X}$ & 5 \\
\hline
\end{tabular}

Quadro 7 - Resumo dos critérios de localização de instalações que podem ser utilizados na decisão de armazenagem

\subsubsection{Critérios para tomada de decisão em investimento de armazenagem de soja}

Os critérios a seguir foram compilados a partir de um conjunto de critérios revisados na literatura e que são utilizados pelo MAPA e pela CONAB, para uma adequada armazenagem de soja em grãos.

\subsubsection{Localização e Transporte}

O critério "Localização e Transporte" tem por objetivo avaliar qual é o local que permitirá o melhor plano de movimentação fazenda-armazém e armazém-destino, ou seja, garantir o escoamento da maior quantidade de produto com os menores custos de transporte no tempo requerido pelo mercado para garantir a viabilidade econômica do projeto.

Segundo Ballou (2006) a localização das instalações na rede é o mais importante problema de planejamento estratégico de logística e cadeia de suprimentos para grande parte das empresas. No caso da cadeia da soja no Brasil, como a produção é grande e concentrada no período da colheita, exige a localização de instalações múltiplas, e os métodos que podem ser utilizados para solucionar este tipo problema de localização são de: otimização, simulação e métodos heurísticos.

Oliveira e Caixeta Filho (2007) citam o trecho do Manual elaborado pelo Banco do Nordeste (1968, p. IX) que define muito bem o termo como sendo uma: 
...condicionalidade espacial das atividades econômicas. Ou, em outras palavras, das influências que o espaço geográfico exerce sobre aquelas atividades, uma vez que elas se acham, natural e necessariamente, condicionadas pela distribuição espacial dos recursos de produção, de um lado, e dos aglomerados humanos, do outro; o que implica de um ponto de vista da Economia, em introduzir-se, ou no estudo teórico ou no tratamento empírico das mesmas, a variável distância.

A importância da localização na posição estratégica da empresa é enfatizada por Yang e Lee (1997) devido ao seu impacto nos custos operacionais, velocidade e desempenho da entrega, como também na flexibilidade para competir no mercado. De acordo com as especificidades de cada empresa, os objetivos podem ser baseados em uma das quatro principais vertentes: minimizar custo, orientar pela demanda, maximizar lucro ou posicionar segundo alguma oportunidade de mercado.

Como exemplo de medição de um problema de localização, vale citar o modelo proposto por Oliveira e Caixeta Filho (2007) que desenvolveram um modelo de otimização para determinar os locais mais adequados para instalação de armazéns granel para uma commodity agrícola, com o objetivo de minimizar custos de transporte e de armazenagem.

Quanto ao transporte, a movimentação rodoviária de soja apresenta um papel de destaque no transporte de granéis agrícolas, pois devido às condições de infraestrutura existentes é o caminhão que realiza o transporte das lavouras para o seu primeiro destino, geralmente, o armazém e, esta tarefa, exigem grandes volumes. Caixeta Filho et al (2001) afirma que a oferta de veículos não é suficiente para cobrir a demanda existente para movimentação da soja e outros produtos agrícolas, o que proporciona um aumento significativo dos fretes.

Mas, Gameiro (2003) salienta que o conhecimento destas rotas e quantidades movimentadas são informações relativamente difíceis de serem obtidas no caso do modal rodoviário, que principalmente pela sua regulamentação, não dispõe de um serviço amplo de registo. E discorre, que, geralmente, tais informações são obtidas por meio de estimativas das quantidades ofertadas nas regiões produtoras e das quantidades demandadas nas regiões de destino.

Assim, Gameiro (2003) define frete como a importância ou preço pago pelo serviço de transporte de alguma mercadoria. Segundo Martins et al (2008) destaca a importância do custeio como um dos critérios mais frequentemente utilizados de parametrização do desempenho nas cadeias de suprimentos. Explica que os transportes agregam custos 
diretamente referentes aos fretes pagos e, indiretamente, por meio de sua eficiência operacional que transborda para as demais atividades e operações da logística, segundo os inúmeros trade-offs com o composto logístico, tais como as decisões de centralização ou não dos estoques na cadeia, as políticas de armazenagem, o número, a localização e o tamanho das instalações logísticas, dentre outros.

O conhecimento dos fatores que interferem no frete também é importante para prever qualquer flutuação que possa impactar na viabilidade econômica do projeto. Em linhas gerais, Martins et al (2008) observa uma concentração de abordagens que consideram a distância como principal fator de determinação do preço de frete, pois impacta, dessa forma, os custos variáveis (quilometragem rodada) do serviço, independentemente do modal utilizado. Correa Júnior et al. (2001) afirmam também que, de modo geral, estudos que procuram identificar os determinantes dos fretes rodoviários são, primeiramente, dependentes das distâncias e, posteriormente, ajustados por outros fatores.

Gameiro (2003) levanta os fatores que podem impactar na formação do frete na determinação de índices de preços para o transporte de cargas de soja a granel, como mostra o Quadro 8.

\begin{tabular}{cccc}
\hline Custos & Carga & Veículo & Mercado \\
\hline Distância & Peso & Número de vagões & Origem/destino \\
\hline Custos & Preço & Tamanho & Época \\
\hline Combustível & Volume & Lotação & Oferta \\
\hline Tempo (h) & Densidade & Acondicionamento & Demanda \\
\hline Carga/descarga & Perecibilidade & & Carga de \\
\hline Salários & Tipo de carga & Retorno \\
\hline Risco de Greve & & Nível de serviço \\
\hline Fronteiras & & Contrato \\
\hline Condição das vias & & Rotas \\
\hline 8- Variáveis que podem & & \\
\hline
\end{tabular}

\section{Quadro 8- Variáveis que podem influenciar a precificação do frete}

Fonte: Gameiro (2003) adaptado por Martins et al (2008).

Ainda, Lacerda Filho et al (2000) sugerem uma análise que descreva os modais existentes na região: rodovia, ferrovia e/ou hidrovia, avaliando seu estado de conservação e possíveis mudanças no sistema de transporte que possibilitem futuras alterações na direção do fluxo de produção agrícola para outras regiões, considerando a área de influência da unidade. 


\subsubsection{Estudo de Mercado}

O entendimento de como o mercado da soja se comporta, assim como possíveis fatores que podem impactar na oferta e demanda são de extrema importância para sucesso de um projeto de armazenagem, já que a garantia de volume armazenado e margem de comercialização garantirá a viabilidade econômica da unidade armazenadora. Como já foi dito anteriormente, o destino da soja armazenada pode ser tanto a uma empresa esmagadora (mercado interno), como exportação nos meses de entressafra.

Quando se analisa a estrutura de mercado procura-se medir o nível de concentração do mercado, avaliar se o mercado apresenta características de forte competição entre as empresas ou se existem mecanismos de controle da demanda e/ou da oferta (SOUZA FILHO et al, 2007). Os mesmos autores sugerem alguns indicadores de concentração que podem ser construídos para compor a análise:

-Número total de propriedades, empresas processadoras e intermediárias que participam do mercado interno e exportação;

-Participação de pequenas, médias e grandes propriedades rurais na produção total;

-Evolução do market-share das empresas líderes;

-Área média das propriedades;

- Descrição da evolução recente das fusões e incorporações de empresas;

- Identificação das alterações na posição de algumas empresas de um ano para o outro;

- Caracterização das empresas líderes, procurando identificar a capacidade instalada de produção, o número de unidades de processamento, estocagem e preços, qualidade, transporte, direitos trabalhistas, direitos humanos, especialmente aquelas que são objeto de maior conflito.

- Identificação das principais organizações, tais como associações de produtores, sindicatos, associações de empresas processadoras, organizações governamentais e seu papel na definição de políticas públicas ou privadas. Em especial, deve-se apontar seu campo de atuação e seu papel na coordenação do sistema. 
O descompasso entre a sazonalidade da produção de grãos e o seu consumo ininterrupto promove, caso não se tenha uma capacidade estática de armazenamento suficiente para a formação de estoques reguladores, uma flutuação dos preços dos produtos. Além das variações estacionais, verificadas todos os anos, existem também, variações interanuais causadas por intempéries naturais ou pela falta de estímulos ao produtor, promovida pela queda dos preços dos grãos. Para se evitar esse tipo de flutuação faz-se necessária a constituição de estoques de longo prazo, que permitam equalizar a oferta com a demanda, mantendo assim, os preços equilibrados (FREDERICO, 2010).

\subsubsection{Infraestrutura e aspectos regionais}

O critério "infraestrutura e aspectos regionais" avalia a região na qual serão alocados os projetos em estudo sob três principais aspectos: agrícolas, sociais e sobre o tema deste estudo que é a demanda por armazenagem.

Lacerda Filho et al (2000) sugere estimar com base em pelo menos cinco anos e para cada produto, a possibilidade de aumento de produtividade ou de produção pelo aumento da área plantada. Uma análise dos períodos de colheita, estabelecendo o início e o final de cada safra, com estimativas de quantidade colhida em cada mês também se faz necessário para caracterizar a região.

Análises de fluxos de carga e sazonalidade de armazenamento, custos de armazenagem e informações qualitativas sobre o mercado agrícola podem ser incorporados na avaliação desse critério. Estas informações podem ser obtidas pelo Siarma (Sistema de Informações de Armazenagem), que de maneira integrada com o SIFRECA, têm se mostrado essenciais ao dimensionamento de projetos logísticos voltados para os complexos agroindustriais.

\subsubsection{Análise de Viabilidade Econômica}

A análise de viabilidade econômica pode ser composta por dois principais fatores: análise de investimento e análise de custos. Para ambos, a literatura é vasta em métodos para a sua mensuração. Nesta dissertação, será descrito resumidamente os principais. 
O valor presente líquido (VPL) de um projeto de investimento pode ser definido como a soma algébrica dos valores descontados do fluxo de caixa a ele associado. Em outras palavras, é a diferença do valor presente das receitas menos o valor presente dos custos (SILVA e FONTES, 2005). Assim:

$$
V P L=\sum_{j=0}^{n} R_{j}(1+i)^{-j}-\sum_{j=0}^{n} C_{j}(1+i)^{-j}
$$

Em que:

$\mathrm{Rj}=$ valor atual das receitas;

$\mathrm{Cj}=$ valor atual dos custos;

$\mathrm{i}=$ taxa de juros;

$\mathrm{j}$ =período em que as receitas ou os custos ocorrem; e

$\mathrm{n}=$ número de períodos ou duração do projeto.

O projeto que apresenta o VPL maior que zero (positivo) é economicamente viável, sendo considerado o melhor aquele que apresentar maior VPL. Para uso desse método, é necessária a definição de uma taxa de desconto (i).

Para a aplicação do método do VPL a projetos ou ativos com risco, Carbinatto (2003) questiona duas premissas fundamentais:

(1) Fluxos de caixa incertos são substituídos pelo seu valor projetado, estimado no início da vida útil do projeto. Ainda, assume-se uma gerência passiva da empresa, sem revisão de decisões estratégicas. Dessa forma, interpreta-se que as decisões implementadas não podem ser revistas, retirando a flexibilidade característica do gerenciamento de projetos e empresas;

(2) As premissas para a taxa de desconto são sua definição e manutenção constante ao longo do tempo, dependendo exclusivamente do risco do projeto, também constante no decorrer do tempo. Há dois métodos básicos, entre outros, para definição da taxa de desconto: (1) o Custo Médio Ponderado de Capital (WACC - Weighted Average Cost of Capital), aplicado para toda a empresa, ou em alguns casos, apenas para uma divisão específica; e (2) o Valor 
Presente Ajustado (APV - Adjusted Present Value), inicialmente proposto por Stewart C. Myers em 1974, e que considera riscos diferentes para cada componente do fluxo de caixa.

Carbinatto (2003) ressalta que as principais críticas ao modelo VPL referem-se à primeira premissa. A flexibilidade gerencial permite a capitalização de futuras oportunidades favoráveis à empresa ou projeto, e também permite reduzir perdas, aumentando o valor da oportunidade de realização de um investimento ao incrementar a possibilidade de ganhos e limitar o potencial de perdas (TRIGEORGIS, 1993). Assim como sugerem Hayes e Garvin (1982), dada às deficiências do método do fluxo de caixa descontado, julgamentos e observações estratégicas subjetivas deveriam compor a base das decisões sobre projetos, sem, entretanto distorcer os métodos quantitativos aplicados.

Para a análise de custos, Ballou (2006) sugere que as decisões sobre estratégias logísticas devem ser baseadas no arranjo entre os diferentes componentes logísticos: estrutura de instalações; processamento de pedidos; manutenção de informação; transporte; manutenção de estoques; armazenagem e manuseio. Estas decisões são baseadas em análise de balanceamento entre os componentes para buscar menor custo total.

Martins et al (2005) discorrem sobre alguns princípios fundamentais que auxiliam o tratamento integrado das atividades logísticas nas empresas. Merecem ser destacados:

- Compensação de custos: Este conceito reconhece que há comportamentos conflitantes, se os componentes logísticos forem considerados individualmente. Para a minimização dos custos deve-se fazer um balanceamento entre outros componentes logísticos. Como exemplo, Ballou (2006) utilizou os custos relacionados ao número de depósitos existentes num sistema de distribuição, conforme Figura 14. 


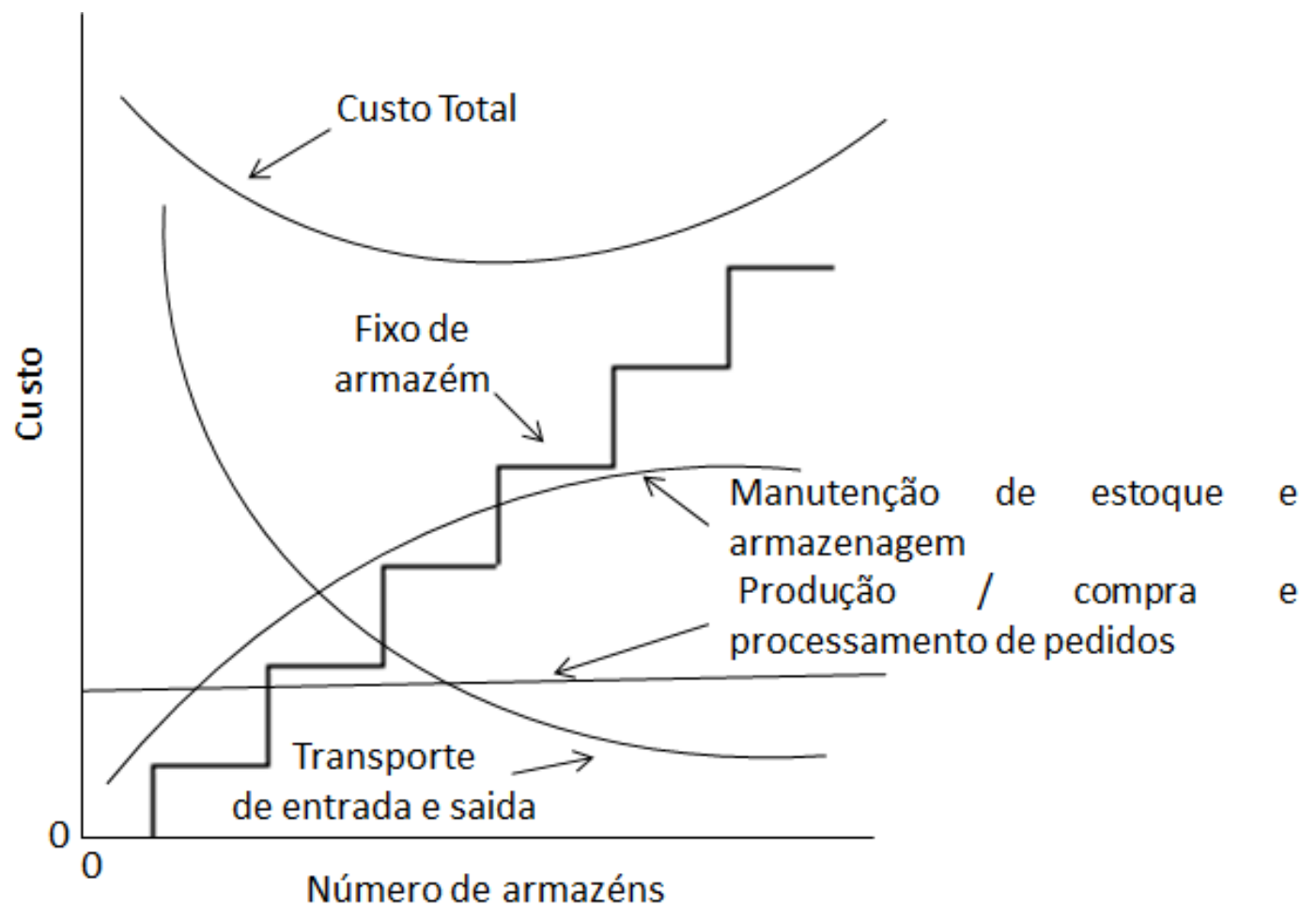

Figura 14 - Compensação de Custos para determinação do total de depósitos de um sistema de múltiplos armazéns.

Fonte: Ballou (2006)

. Conceito de custo total: Os conceitos de custo total e compensação de custos caminham lado a lado. Conforme mostra a Figura 16, custo total é a soma dos custos de transporte, estoque e processamento de pedidos. Assim, o ponto mínimo da curva de custo total situa o número de armazéns que melhor minimiza custos.

Conceito de sistema total: Este conceito é uma extensão do conceito de custo total; porém o enfoque do sistema total leva em consideração todos os fatores afetados, de alguma forma, pelos efeitos da decisão tomada, isto é, relaciona-se diretamente com muitas outras áreas funcionais, dentro e fora dos limites legais da empresa.

Assim, uma decisão primária na rede logística pode estar vinculada às decisões sobre transporte e armazenagem. A confiabilidade e a agilidade dos transportes poderão implicar menores quantidades armazenadas, por exemplo, numa perspectiva de interação dos custos totais e nível do serviço. As estratégias logísticas serão modeladas, considerando-se os atributos desejados pelo negócio e o que pode ser viabilizado pelas atividades primárias de transporte e armazenagem (MARTINS et al, 2005). 


\subsubsection{Aspectos de engenharia}

Este critério é baseado na Instrução Normativa No 29, de 8 junho de 2011, que consolida todas as normas e procedimentos a serem adotados na implantação do Sistema Nacional de Certificação de Unidades Armazenadoras. Este documento estabelece os requisitos técnicos obrigatórios ou recomendados para construção, instalação e funcionamento de estruturas de armazenamento, visando a modernização do setor. No quadro 6, encontra-se um resumo dos requisitos técnicos obrigatórios $(\mathrm{O})$ ou recomendados $(\mathrm{R})$ para uma unidade armazenadora granel em ambiente natural, objeto de estudo desta dissertação.

\begin{tabular}{|c|c|c|c|c|}
\hline Requisitos & Nível Fazenda & Coletor & Intermediário & Terminal \\
\hline \multicolumn{5}{|l|}{ 1. CADASTRAMENTO } \\
\hline $\mathrm{Na}$ Conab & $\mathrm{O}$ & $\mathrm{O}$ & $\mathrm{O}$ & $\mathrm{O}$ \\
\hline Mapeamento da unidade & $\mathrm{R}$ & $\bar{R}$ & $\bar{R}$ & $\bar{R}$ \\
\hline \multicolumn{5}{|l|}{ 2. LOCALIZAÇÃO } \\
\hline Topografia & $\mathrm{R}$ & $\mathrm{R}$ & $\mathrm{R}$ & $\mathrm{R}$ \\
\hline Drenagem & $\mathrm{O}$ & $\mathrm{O}$ & $\mathrm{O}$ & $\mathrm{O}$ \\
\hline Lençol freático & $\mathrm{R}$ & $\mathrm{R}$ & $\mathrm{R}$ & $\mathrm{R}$ \\
\hline Não proximidade centros urbanos & $\mathrm{R}$ & $\mathrm{R}$ & $\mathrm{R}$ & $\mathrm{R}$ \\
\hline Não proximidade de mananciais & $\mathrm{R}$ & $\mathrm{R}$ & $\mathrm{R}$ & $\mathrm{R}$ \\
\hline \multicolumn{5}{|l|}{ 3. INFRAESTRUTURA } \\
\hline \multicolumn{5}{|l|}{ Viária } \\
\hline - Acesso permanente & $\mathrm{O}$ & $\mathrm{O}$ & $\mathrm{O}$ & $\mathrm{O}$ \\
\hline - Pátio pavimentado & $\mathrm{R}$ & $\mathrm{O}$ & $\mathrm{O}$ & $\mathrm{O}$ \\
\hline Comunicação & $\mathrm{O}$ & $\mathrm{O}$ & $\mathrm{O}$ & $\mathrm{O}$ \\
\hline Energia Elétrica & $\mathrm{O}$ & $\mathrm{O}$ & $\mathrm{O}$ & $\mathrm{O}$ \\
\hline Sinalização de Trânsito & $\mathrm{O}$ & $\mathrm{O}$ & $\mathrm{O}$ & $\mathrm{O}$ \\
\hline \multicolumn{5}{|l|}{ 4. ISOLAMENTO/ACESSO } \\
\hline Cerca e portão & $\mathrm{O}$ & $\mathrm{O}$ & $\mathrm{O}$ & $\mathrm{O}$ \\
\hline Segurança & $\mathrm{R}$ & $\mathrm{R}$ & $\mathrm{R}$ & $\mathrm{R}$ \\
\hline Guarita de controle & $\mathrm{R}$ & $\mathrm{R}$ & $\mathrm{R}$ & $\mathrm{R}$ \\
\hline \multicolumn{5}{|l|}{ 5. AMBIENTE DE ATENDIMENTO } \\
\hline Estacionamento & $\mathrm{R}$ & $\mathrm{O}$ & $\mathrm{O}$ & $\mathrm{O}$ \\
\hline Instalações sanitárias & $\mathrm{R}$ & $\mathrm{O}$ & $\mathrm{O}$ & $\mathrm{O}$ \\
\hline \multicolumn{5}{|l|}{ 6. ESCRITÓRIO } \\
\hline Instalações sanitárias & $\mathrm{O}$ & $\mathrm{O}$ & $\mathrm{O}$ & $\mathrm{O}$ \\
\hline Arquivos de Documentos & $\mathrm{O}$ & $\mathrm{O}$ & $\mathrm{O}$ & $\mathrm{O}$ \\
\hline Informatização & $\mathrm{O}$ & $\mathrm{O}$ & $\mathrm{O}$ & $\mathrm{O}$ \\
\hline \multicolumn{5}{|l|}{ 7. SISTEMA DE PESAGEM } \\
\hline Balança de plataforma rodoviária & $\mathrm{O}$ & $\mathrm{O}$ & $\mathrm{O}$ & $\mathrm{O}$ \\
\hline \multicolumn{5}{|l|}{ 8.SISTEMA DE AMOSTRAGEM } \\
\hline \multicolumn{5}{|l|}{ Amostradores básicos } \\
\hline - Calador para produto granel & $\mathrm{O}$ & $\mathrm{O}$ & $\mathrm{O}$ & $\mathrm{O}$ \\
\hline - Amostrador pneumático & $\mathrm{R}$ & $\mathrm{R}$ & $\mathrm{R}$ & $\mathrm{R}$ \\
\hline
\end{tabular}




\begin{tabular}{|c|c|c|c|c|}
\hline Requisitos & Nível Fazenda & Coletor & Intermediário & Terminal \\
\hline - Amostrador de fluxo & $\mathrm{R}$ & $\mathrm{R}$ & $\mathrm{R}$ & $\mathrm{R}$ \\
\hline Sonda manual & $\mathrm{R}$ & $\mathrm{R}$ & & \\
\hline Sistema de homogeneização & $\mathrm{O}$ & $\mathrm{O}$ & $\mathrm{O}$ & $\mathrm{O}$ \\
\hline Arquivo de amostras & $\mathrm{O}$ & $\mathrm{O}$ & $\mathrm{O}$ & $\mathrm{O}$ \\
\hline \multicolumn{5}{|l|}{ 9. DETERMINAÇÃO DE } \\
\hline \multicolumn{5}{|l|}{ QUALIDADE DE PRODUTO } \\
\hline Recinto de análise & $\mathrm{O}$ & $\mathrm{O}$ & $\mathrm{O}$ & $\mathrm{O}$ \\
\hline Determinador de umidade indireto & $\mathrm{O}$ & $\mathrm{O}$ & $\mathrm{O}$ & $\mathrm{O}$ \\
\hline Determinador de umidade direto & $\mathrm{R}$ & $\mathrm{R}$ & $\mathrm{R}$ & $\mathrm{R}$ \\
\hline Determinador de umidade de fluxo & $\mathrm{R}$ & $\mathrm{R}$ & $\mathrm{R}$ & $\mathrm{R}$ \\
\hline Determinador de impurezas mecânicos & $\mathrm{R}$ & $\mathrm{R}$ & $\mathrm{R}$ & $\mathrm{R}$ \\
\hline Identificador de transgenia & $\mathrm{R}$ & $\mathrm{R}$ & $\mathrm{R}$ & $\mathrm{R}$ \\
\hline Indicador de toxina & $\bar{R}$ & $\bar{R}$ & $\mathrm{R}$ & $\mathrm{R}$ \\
\hline Balança de precisão & $\mathrm{O}$ & $\mathrm{O}$ & $\mathrm{O}$ & $\mathrm{O}$ \\
\hline Balança hectolítrica & $\mathrm{R}$ & $\mathrm{R}$ & $\mathrm{R}$ & $\mathrm{R}$ \\
\hline Jogo de Peneiras & $\mathrm{O}$ & $\mathrm{O}$ & $\mathrm{O}$ & $\mathrm{O}$ \\
\hline Acessórios (lupa, paquímetro...) & $\mathrm{R}$ & $\mathrm{R}$ & $\mathrm{R}$ & $\mathrm{R}$ \\
\hline \multicolumn{5}{|l|}{ 10. SISTEMA DE LIMPEZA } \\
\hline Sistema de Limpeza & $\mathrm{O}$ & $\mathrm{O}$ & $\mathrm{O}$ & $\mathrm{R}$ \\
\hline \multicolumn{5}{|l|}{ 11. SISTEMA DE SECAGEM } \\
\hline Sistema de Secagem & $\mathrm{O}$ & $\mathrm{O}$ & $\mathrm{O}$ & $\mathrm{R}$ \\
\hline \multicolumn{5}{|l|}{ 13. SISTEMA DE MOVIMENTAÇÃO } \\
\hline Moega & $\mathrm{O}$ & $\mathrm{O}$ & $\mathrm{O}$ & $\mathrm{O}$ \\
\hline Transporte/movimentação & $\mathrm{O}$ & $\mathrm{O}$ & $\mathrm{O}$ & $\mathrm{O}$ \\
\hline \multicolumn{5}{|l|}{ 14. SISTEMA DE ARMAZENAGEM } \\
\hline Sistema de controle elétrico & $\mathrm{O}$ & $\mathrm{O}$ & $\mathrm{O}$ & $\mathrm{O}$ \\
\hline Sistema de termometria & $\mathrm{O}$ & $\mathrm{O}$ & $\mathrm{O}$ & $\mathrm{R}$ \\
\hline Sistema de aeração & $\mathrm{O}$ & $\mathrm{O}$ & $\mathrm{O}$ & $\mathrm{R}$ \\
\hline Espalhador de grãos & $\mathrm{R}$ & $\mathrm{R}$ & $\mathrm{R}$ & $\mathrm{R}$ \\
\hline $\begin{array}{l}\text { Higienização nas unidades } \\
\text { armazenadoras, instalações físicas, } \\
\text { equipamentos e pátio }\end{array}$ & $\mathrm{O}$ & $\mathrm{O}$ & $\mathrm{O}$ & $\mathrm{O}$ \\
\hline Controle pragas e roedores & $\mathrm{O}$ & $\mathrm{O}$ & $\mathrm{O}$ & $\mathrm{O}$ \\
\hline Sistema de exaustão & $\mathrm{O}$ & $\mathrm{O}$ & $\mathrm{O}$ & $\mathrm{O}$ \\
\hline $\begin{array}{l}\text { Sistema de medição condições } \\
\text { psicométrica do ar }\end{array}$ & $\mathrm{O}$ & $\mathrm{O}$ & $\mathrm{O}$ & \\
\hline \multicolumn{5}{|l|}{ 15. SISTEMA DE SEGURANÇA } \\
\hline $\begin{array}{l}\text { Sistema de captação de material } \\
\text { particulado }\end{array}$ & $\mathrm{O}$ & $\mathrm{O}$ & $\mathrm{O}$ & $\mathrm{O}$ \\
\hline $\begin{array}{l}\text { Sistema de ventilação de ambientes } \\
\text { confinados e semi-confinados }\end{array}$ & $\mathrm{O}$ & $\mathrm{O}$ & $\mathrm{O}$ & $\mathrm{O}$ \\
\hline Sistema de combate de incêndio & $\mathrm{O}$ & $\mathrm{O}$ & $\mathrm{O}$ & $\mathrm{O}$ \\
\hline Indicador ou detector de gases & $\mathrm{R}$ & $\mathrm{R}$ & $\mathrm{R}$ & $\mathrm{R}$ \\
\hline $\begin{array}{l}\text { Sistema de proteção contra fenômenos } \\
\text { naturais }\end{array}$ & $\mathrm{R}$ & $\mathrm{R}$ & $\mathrm{R}$ & $\mathrm{R}$ \\
\hline
\end{tabular}




\begin{tabular}{lllll}
\hline \multicolumn{1}{c}{ Requisitos } & Nível Fazenda & Coletor & Intermediário & Terminal \\
\hline DEMAIS REQUISITOS & & & & \\
\hline Responsável técnico & $\mathrm{O}$ & $\mathrm{O}$ & $\mathrm{O}$ & $\mathrm{O}$ \\
\hline Monitoramento de resíduos tóxicos & $\mathrm{R}$ & $\mathrm{R}$ & $\mathrm{R}$ & $\mathrm{R}$ \\
\hline $\begin{array}{l}\text { Programa de treinamento e } \\
\text { aperfeiçoamento técnico }\end{array}$ & $\mathrm{O}$ & $\mathrm{O}$ & $\mathrm{O}$ & $\mathrm{O}$ \\
\hline $\begin{array}{l}\text { Registros de ocorrências operacionais } \\
\text { Monitoramento de micotoxinas }\end{array}$ & $\mathrm{O}$ & $\mathrm{O}$ & $\mathrm{O}$ & $\mathrm{O}$ \\
\hline Quadro de pessoal & $\mathrm{R}$ & $\mathrm{R}$ & $\mathrm{R}$ & $\mathrm{R}$ \\
\hline $\begin{array}{l}\text { Plano de manutenção preventiva e } \\
\text { calibração de equipamentos }\end{array}$ & $\mathrm{O}$ & $\mathrm{O}$ & $\mathrm{O}$ & $\mathrm{O}$ \\
\hline
\end{tabular}

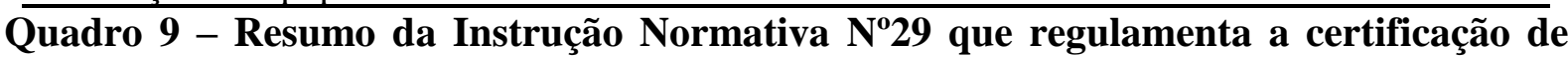
armazéns granéis

Fonte (Mapa, 2012)

\subsubsection{Capacidade e eficiência operacional}

Este critério mede o potencial do projeto em garantir o alcance do objetivo do armazenamento que é guardar e preservar as características que os grãos apresentam após a colheita, diminuindo ao máximo as perdas, utilizando-se, da melhor maneira possível, as técnicas existentes (BROOKER et al., 1992; AZEVEDO et al, 2008; KNOB, 2010). Este critério está diretamente relacionado à: capacidade estática, utilização do armazém (giros de estoque), eficiência dos sistemas e linhas de processamento e qualidade do produto.

Dois tipos de perdas podem ocorrer nos grãos numa unidade de armazenagem: perda física ou quebra e perda de qualidade. A perda por quebra ocorre quando o produto sofre uma perda de peso pelos danos mecânicos causados na movimentação, por animais e/ou insetos. Enquanto a perda de qualidade é aquela que ocorre quando as qualidades intrínsecas, essenciais do produto, são alteradas, principalmente, pela ação de fungos, umidade e temperatura, os quais causam fermentações, modificações organolépticas (alterações do gosto e cheiro natural do produto) e redução do valor nutritivo dos grãos (D’ARCE, 2012).

As técnicas existentes para reduzir tais perdas, como já citado na seção 3.1.3 Unidade Armazenadora, são compostas pelos sistemas de limpeza, movimentação, secagem, aeração, termometria e higienização.

A capacidade estática e a utilização do armazém são as informações que avaliam o potencial de volume que será armazenado no cálculo de viabilidade econômica do projeto. A 
capacidade estática de armazenagem pode ser definida como a quantidade de grãos que cabe de uma só vez, confinada, em uma unidade armazenadora (em toneladas), enquanto a utilização do armazém pode ser calculada pela quantidade de grãos que entrou e saiu de uma unidade armazenadora no período de um ano (capacidade dinâmica), dividida pela capacidade do armazém.

\subsection{Decisão em Grupo}

Decisão em grupo é usualmente entendida como uma agregação das preferências individuais a respeito de mesmos critérios e alternativas. Ou seja, envolvem múltiplos tomadores de decisão, cada um com suas competências, conhecimento e experiências diferentes. Contudo, assume-se que os indivíduos participantes em face ao problema estejam interessados na sua solução.

Morais e Almeida (2012) citaram o trabalho de Bose et al (1999) que contém algumas aplicações de MAUT com sugestões e discussões de como poderiam ser incorporadas numa ferramenta de decisão em grupo, ademais sua análise mostra que o método é apropriado para tal aplicação, mas que não tem sido muito utilizada pela sua complexidade. Além disso, concluiu que se um processo de votação fosse necessário para obter uma conclusão, uma simples programação aceita pelo grupo seria a melhor opção.

O Analytic Hierarchy Process (AHP) de Satty (1980) também é um método de decisão que permite adaptação para tomada de decisão em grupo. Vários processos são usados para agregar as preferências dos tomadores de decisão, com os dois mais populares sendo: (1) Aggregating Individual Judgment (AIJ), que consiste em agregar julgamentos individuais em relação a cada conjunto de comparações de pares para produzir uma hierarquia de agregados; (2) Aggregating Individual Priorities (AIP), que visa sintetizar cada uma das hierarquias individuais e agregando as prioridades resultantes (Forman e Peniwati, 1998).

Wu et al (2008) afirmam que na prática os pesquisadores e tomadores de decisão utilizam tanto AIJ e AIP, mas salientam que a agregação de opiniões de especialistas pode ser um problema, porque a agregação diferente dos dois métodos pode causar pesos diferentes e influenciar a decisão. Aczel e Satty (1983) e Aczel e Roberts (1989) demonstraram que a aplicação geométrica de matriz de paridade AHP com os julgamentos individuais satisfazem o Princípio de Pareto (condição de unanimidade) e homogeneidade condição. No entanto, 
Forman e Peniwati (1998) explicaram que o procedimento matemático ideal para a agregação depende se o grupo é assumido como sendo uma unidade entrosada ou simplesmente uma coleção de indivíduos. Além disso, Forman e Peniwati (1998) discutiram que tanto a média geométrica como a média aritmética são procedimentos adequados para escalas de razão, mas o conceito desta teoria considera que os pesos dos critérios respeitem a condição de consistência e transitividade.

Aggregating Individual Priorities (AIP) pode ser utilizado em processos de decisão em que o grupo seja formado por indivíduos que não apresentam entrosamento e objetivos comuns. Estes tipos de decisores tendem a agir de acordo com suas preferências, seus valores e objetivos. Já o método Aggregating Individual Judgment (AIJ) é indicado, somente, para um grupo muito entrosado num processo de tomada de decisão, pois este método pede um consenso e, nesse caso, por ser considerada utópica (Cruz, 2011).

A partir dessa afirmação, optou-se por uma abordagem de pesquisa individual utilizando uma adaptação da técnica Aggregating Individual Priorities (AIP) aplicada no método de AHP por Cruz (2011). Foi escolhida esta abordagem nesta dissertação, pois o grupo de decisores em questão apesar de apresentar entrosamento entre si possui conflitos de interesses por pertenceram a áreas diferentes. Este é o assunto da próxima seção - Metodologia de pesquisa. 


\section{METODOLOGIA}

A pesquisa proposta pode ser caracterizada como uma pesquisa aplicada, já que visa gerar conhecimentos a partir de uma análise de investimento e análise multicritério de apoio à decisão, utilizando o método de MAVT para construção de um modelo de tomada de decisão sobre armazenagem na cadeia de suprimentos da soja em grão.

O objeto de estudo é um modelo multicritério que auxilie o processo de tomada de decisão sobre investimento em armazenagem granel sob a visão de uma trading do setor. O modelo foi elaborado a partir de uma árvore de decisão composta por critérios e atributos relevantes ao tema abordado. Esses critérios e atributos foram validados e ponderados por profissionais do setor através de um questionário. As ponderações desses critérios e atributos foram agregadas para compor a decisão do grupo. Apesar de não ser um estudo de caso, um exemplo hipotético foi criado para validação do modelo com base no valor de decisão de uma trading.

A metodologia proposta está representada com base no modelo de Belton e Stewart (2002), (Figura 15).

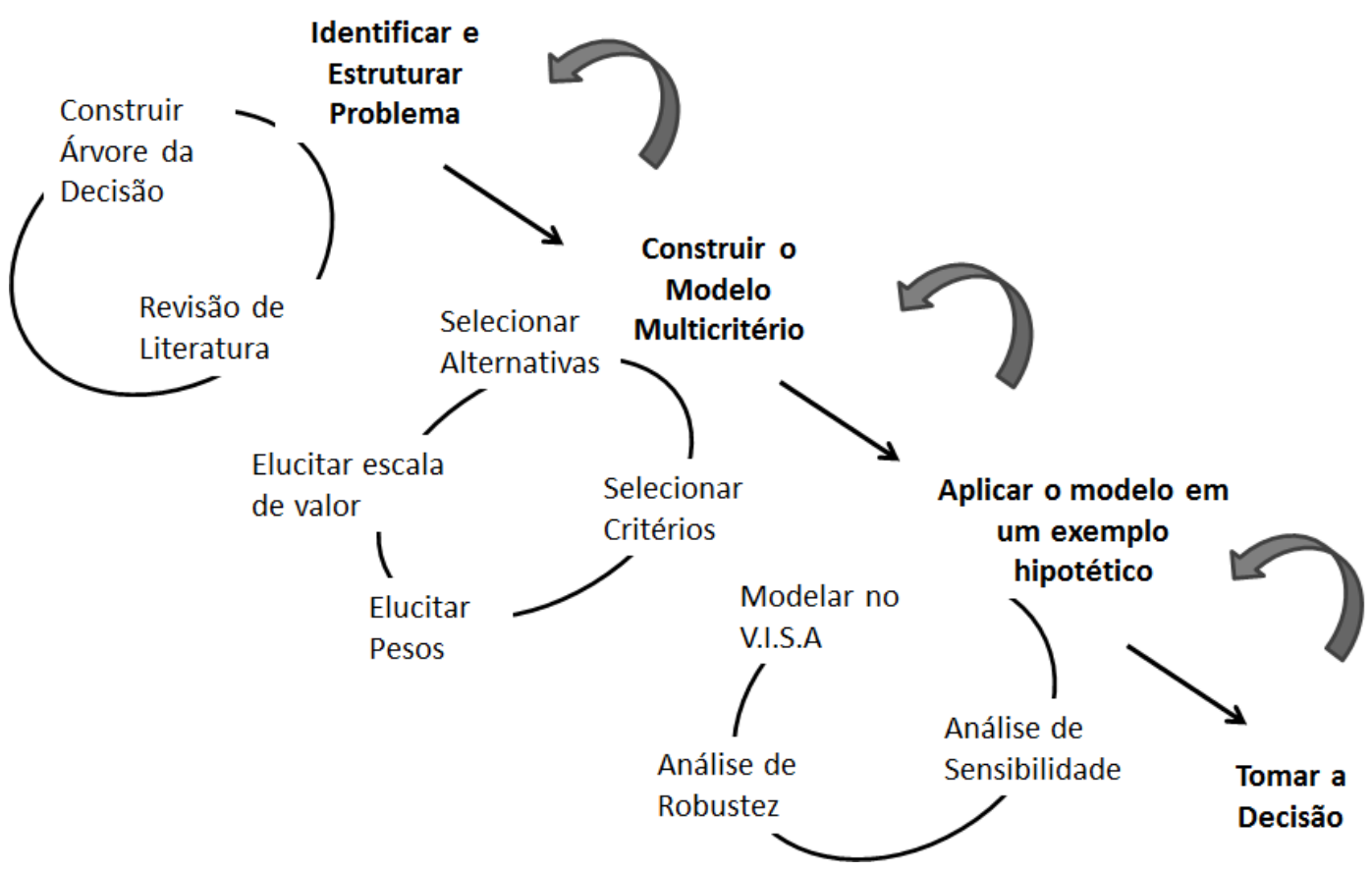

Figura 15 -. Representação do processo de tomada de decisão de investir em armazenagem.

Fonte: Belton e Stewart (2002) 
O modelo proposto por Belton e Stewart (2002) é composto por, basicamente, três etapas: Identificar e estruturar o problema, Construir o modelo multicritério e Aplicação do exemplo hipotético. A primeira etapa representa a fase de levantamento de informações relevantes do problema e a avaliação de sua complexidade. A seguir é a fase de construção do modelo, onde se define os critérios, valores e alternativas que melhor representam a decisão a ser tomada. A última etapa consiste na aplicação do modelo em um exemplo hipotético a fim de analisar a viabilidade da solução proposta pelo modelo e avaliar sua consistência. A seguir serão detalhadas estas etapas de construção do modelo de tomada de decisão de investimento em armazenagem de soja em grão.

\subsection{Etapa 1 - Identificar e Estruturar o Problema}

Num processo de tomada de decisão o primeiro passo é a identificação do problema. Segundo Shimizu (2006), uma estruturação inadequada do problema pode reduzir a eficiência e eficácia do resultado, pois uma formulação errada pode definir o problema errado. Desta maneira, esta etapa é de extrema importância na sugestão de decisão pelo modelo.

A estruturação do problema se baseou numa Revisão de Literatura dos principais fatores que influenciam a gestão da cadeia da soja. O conhecimento gerado será representado através de uma árvore de decisão, como mostra a Figura 16 que exemplifica uma árvore de decisão genérica deste tipo de decisão.

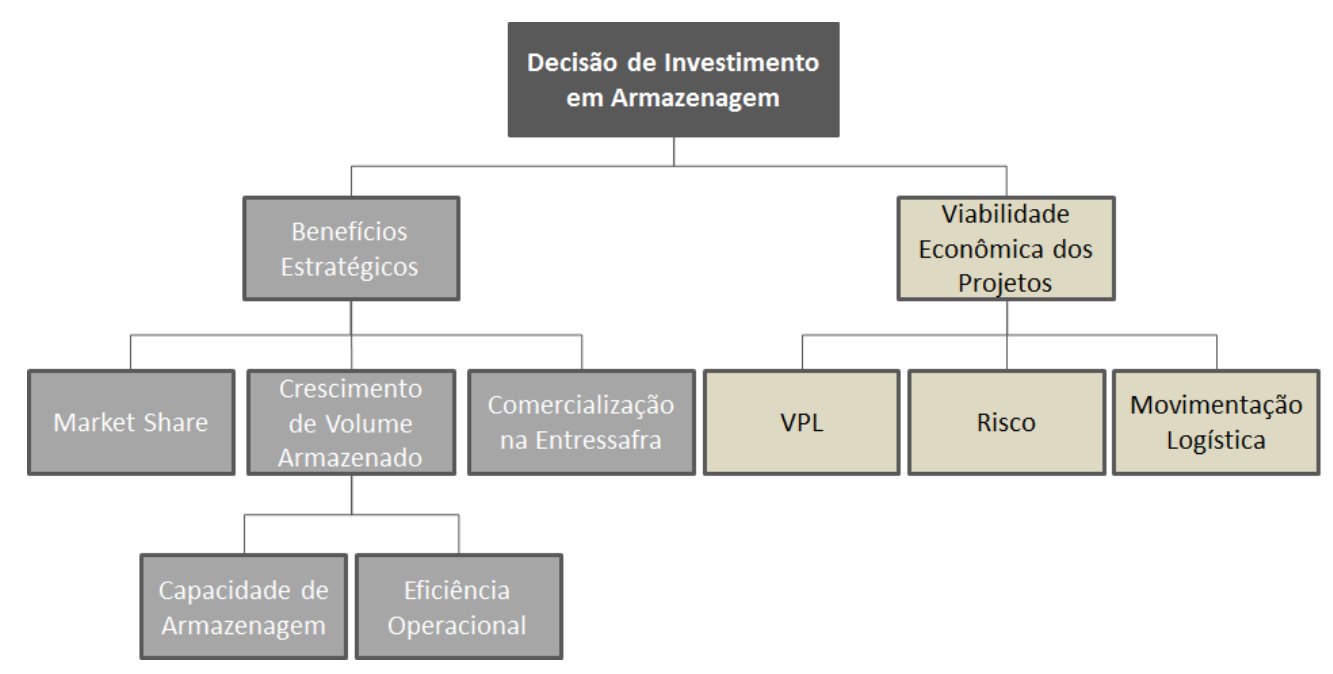

Figura 16 - Exemplo genérico de uma árvore de decisão 


\subsection{Etapa 2 - Construir o Modelo Multicritério}

Segundo Keeney e Gregory (2005), a base do processo de tomada de decisão é o estabelecimento de objetivos. Cada objetivo é uma afirmação do que se quer atingir no contexto da decisão. Para tornar explícito o objetivo é necessário descrever seus três componentes: contexto da decisão, o objeto e a direção de preferência, Keeney (1996). Por exemplo, se o objetivo de uma empresa processadora de grãos for maximizar a aquisição de suprimentos, o contexto da decisão será a cadeia produtiva da soja, o objeto será armazenagem granel, e quanto maior a sua capacidade (direção) garantirá o melhor abastecimento de suas esmagadoras e atendimento de navios no caso de exportação.

Os critérios e atributos representados na árvore irão compor o modelo multicritério no software (Visual Interactive Sensitivity Analysis). Os critérios serão selecionados e ponderados a partir de uma adaptação da técnica de Decisão em Grupo de Forman e Peniwati (1998) Aggregating Individual Priorities (AIP), e da aplicação do método de AHP, por Cruz (2011). Os atributos serão classificados como natural, proxy e construído (Keeney, 1992).

Para o alcance destes objetivos se faz necessário o levantamento das alternativas, a análise de suas consequências, a mensuração de seus impactos (Keeney, 1992) e suas compensações (trade-offs) para atingir mais ou menos os objetivos.

Os métodos de função de valor sintetizam numericamente o desempenho das alternativas (que são medidas em relação a cada critério) com a devida reflexão de importância entre os demais critérios. Porém, Belton e Stewart (2002) ressaltam que o aprendizado e o entendimento que resultam do engajamento dos decisores em todo processo é a maior contribuição do método.

\subsubsection{Método MCDA MAVT}

O modelo pode ser simplificado na função de valor:

$$
V(a)=\sum_{i=1}^{m} w_{i} v_{i}(a)
$$

Onde: 
$\mathbf{V}(\mathbf{a})$ é o valor final da alternativa a ;

$\mathbf{v}_{\mathbf{i}}$ (a) é o valor que reflete o desempenho da alternativa a em relação ao critério i;

$\mathbf{w}_{\mathbf{i}}$ é o peso que reflete a importância do critério i.

As etapas principais deste método são: definir os pesos dos critérios $\mathbf{w}_{\mathbf{i}}$ e sua normalização; determinar a escala de valor $\mathbf{v}_{\mathbf{i}}$ (a) de cada critério para mensurar o valor da alternativa; sintetizar as informações e análises de sensibilidade e robustez para validar o modelo.

\subsubsection{Definição dos pesos}

Num processo de tomada de decisão observa-se que geralmente os critérios não possuem o mesmo peso. Sendo assim, é importante criar uma relação de importância entre os critérios para ponderar os pesos da maneira que melhor reflita a preferência dos tomadores de decisão.

Como se trata de uma decisão em grupo, a definição de pesos será feita pela comparação paritária AHP de Saaty (1980) entre os critérios, através do preenchimento de um questionário individual de cada tomador de decisão envolvido no processo. O método de agregação dessas preferências será o de Agregação Individual de Prioridades (Aggregating Individual Priorities - AIP) que visa sintetizar cada uma das hierarquias individuais através de uma média geométrica das prioridades resultantes. Esta técnica de decisão em grupo foi escolhida, já que o grupo é formado por indivíduos que não apresentam entrosamento e objetivos comuns.

Cruz (2011) utilizou esta abordagem AIP de decisão em grupo para obter uma avaliação global das alternativas e vetores individuais finais de prioridades. Para compor esta análise global das alternativas, foi solicitado que cada indivíduo fizesse comparações de critérios e atributos entre si, e comparações das alternativas entre si sob cada atributo e critério. A adaptação para aplicação nesta dissertação consiste em utilizar a matriz paritária AHP de Saaty (1980) para a obtenção do vetor individual de prioridade dos critérios e AIP para obter a decisão do grupo. A agregação da comparação das alternativas sob cada atributo será feita no software V.I.S.A. utilizando o método MAVT. 
A ponderação dos critérios e atributos desta decisão em grupo contou com a participação de profissionais que atuam em uma trading do setor do agronegócio. O perfil destes profissionais foi composto por analista, coordenador, gerente e diretor das áreas de suprimentos (compra de matéria prima), armazenagem, logística e planejamento. Suas opiniões foram obtidas através de questionário individual como pode ser visto no Apêndice A.

A seleção e ponderação dos critérios da decisão pelos decisores serão compostas pelas seguintes fases como mostra o Quadro 10.

\begin{tabular}{ccc}
\hline Etapa: & Como & Quem \\
\hline $\begin{array}{c}\text { Pré-requisito: Levantamento dos } \\
\text { critérios pertinentes à decisão de } \\
\text { armazenagem de soja em grão }\end{array}$ & $\begin{array}{c}\text { Revisão de Literatura e pesquisa de } \\
\text { mercado }\end{array}$ & Analista \\
\hline $\begin{array}{c}\text { Fase 1: Seleção dos Critérios e } \\
\text { Ponderação }\end{array}$ & $\begin{array}{c}\text { Através de um questionário } \\
\text { Individual (Apêndice A) }\end{array}$ & $\begin{array}{c}\text { Todos os decisores } \\
\text { individualmente }\end{array}$ \\
\hline $\begin{array}{c}\text { Fase 2: Obter a Matriz Paritária com } \\
\text { as ponderações dos critérios }\end{array}$ & Método AHP (Saaty, 1980) & Analista \\
\hline $\begin{array}{c}\text { Fase 3: Normalizar para ter o } \\
\text { ranking e peso de cada critério }\end{array}$ & Método AHP (Saaty, 1980) & Analista \\
\hline $\begin{array}{c}\text { Fase 4: Obter a decisão do grupo } \\
\text { Fase 5: Inserir pesos na árvore de } \\
\text { decisão }\end{array}$ & Através do Método de Aggregating & Analista \\
\hline Individual Priorities (AIP) & Analista \\
\hline
\end{tabular}

Quadro 10 - Etapas para a definição e ponderação dos critérios

\subsubsection{Determinação da escala de valor}

Como sugerido por Keeney (1996) o foco no processo de tomada de decisão será o "Pensamento em Valor", ou seja, a metodologia seguirá a sequência: definição de objetivos a serem atingidos, determinação dos atributos que medirão quantos dos objetivos serão atendidos e seleção das alternativas que serão os meios para que os objetivos sejam alcançados. Explica que para basear-se em "Valor" é necessário torná-lo explícito a partir de um profundo estudo dos objetivos a serem buscados, para depois criar as alternativas que servirão para agregar tais valores.

A determinação de valor, termo em inglês 'Scoring', é o processo de medir o desempenho da alternativa em relação a um critério ou atributo, ou seja, significa medir a função de valor parcial $\mathbf{v}_{\mathbf{i}}(\mathbf{a})$ do modelo (Equação 1). Como os critérios serão construídos na forma de uma árvore de decisão, as alternativas devem ser medidas em relação a todos os níveis da árvore. 
Para construir a escala é necessário definir dois pontos de referência e alocar valores numéricos para cada um desses pontos. Geralmente, eles deverão ser o 0 e 100, mas outros valores podem ser definidos. O máximo e o mínimo da escala podem ser definidos de várias maneiras, mas as escalas mais utilizadas são: local e global (Belton e Stewart, 2002).

A escala local é definida somente entre o conjunto das alternativas que serão consideradas. $\mathrm{Ou}$ seja, a alternativa que apresentar o melhor desempenho em um determinado critério é a que assumirá o valor 100 da escala, e o pior desempenho será posicionado no ponto 0 . As demais alternativas serão alocadas nos valores intermediários de 0 a 100. Enquanto a escala global é definida para um conjunto mais abrangente ao conjunto das alternativas do processo de decisão em questão. O valor 0 e 100 representarão, respectivamente, o pior e o ideal desempenho em situação real.

Uma vez determinado os dois pontos de referência, o próximo passo é definir a função de valor parcial para todo o intervalo da escala de mensuração do atributo. Esta função do valor pode ser feitas de três maneiras, de acordo com a natureza do atributo, são elas:

- Definição da função parcial de valor para atributos quantitativos. Esta função de valor pode ser linear ou não linear, vide Figura 17.

- Construção de uma escala qualitativa para atributos qualitativos. Belton e Stewart (2002) salientam que a elaboração de uma escala qualitativa seja operacional, confiável, relevante e justificável.

- Mensuração direta da alternativa: um valor é determinado e as alternativas são referenciadas segundo este valor específico numa escala qualquer.

Se não for possível identificar uma escala quantitativa apropriada, faz-se necessário construir uma escala qualitativa de maneira que a função de valor reflita as preferências em diferentes níveis da escala. 

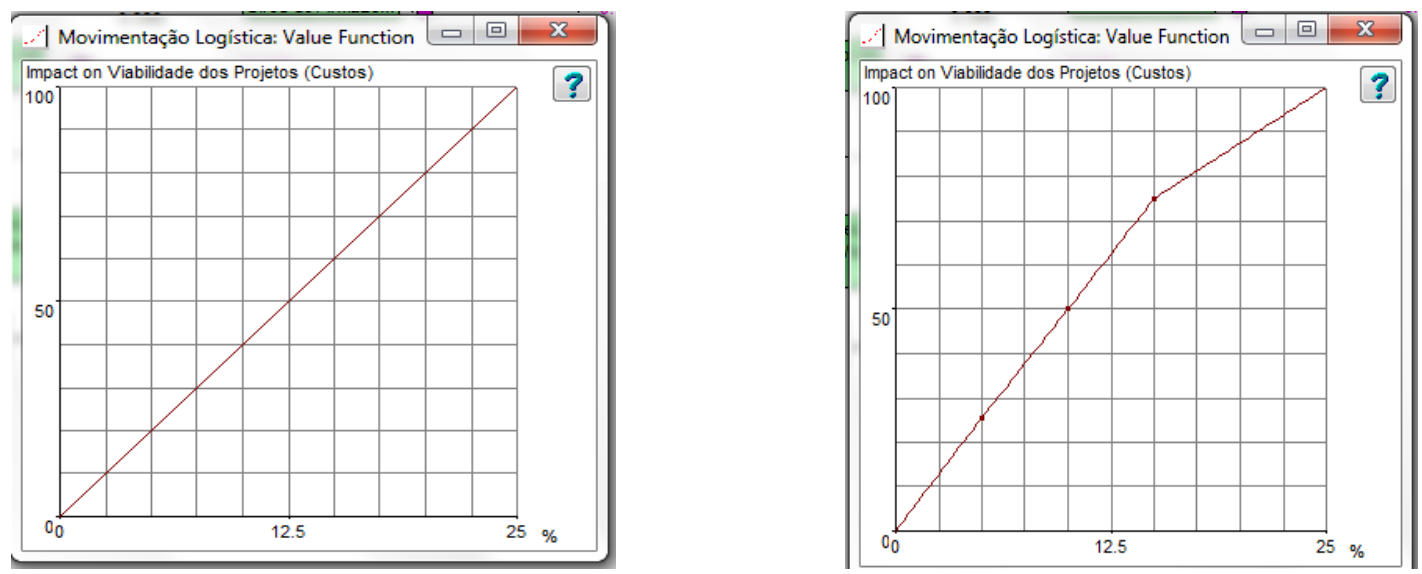

Figura 17 - Ilustração de funções de valor linear e não linear no software V.I.S.A.

No caso da escala quantitativa não linear, o método da Bissecção será escolhido para a definição da função do valor que consiste na determinação dos pontos finais (0 e 100) da curva a partir da preferência dos decisores para o melhor e pior valor. Em seguida, pede-se aos decisores que avaliem qual é o valor que representa o ponto médio (50) entre os valores 0 e 100 na escala de valor. Para finalizar, são solicitados que os decisores determinem quais são os valores que representem os pontos 25 e 75 da curva.

Neste trabalho, a escala de valor para avaliar as alternativas será do tipo local, ou seja, a alternativa que apresentar o melhor desempenho em um determinado critério é a que assumirá o valor 100 da escala e o pior desempenho será posicionado no ponto 0. Os atributos qualitativos serão avaliados por escala de valor de três níveis onde o valor 100 é o alto, 50 é o médio e 0 o valor baixo, critérios quantitativos poderão ser lineares ou não lineares como foi explicado anteriormente. A definição foi feita pelo analista, fato este que pode ser considerado como uma limitação desta pesquisa por não ter as preferências dos decisores nesta etapa.

Para exemplificação de um modelo de decisão de projeto de investimento em unidade armazenadora, alternativas de projetos de armazéns e sua valoração foram criadas para ilustração, as etapas desta valoração encontram-se no Quadro 11.

\begin{tabular}{ccc}
\hline Etapa: & Como & Quem \\
\hline $\begin{array}{c}\text { Pré-requisito: Levantamento das } \\
\text { alternativas de unidades } \\
\text { armazenadoras }\end{array}$ & Revisão de Literatura e pesquisa de \\
mercado & Analista \\
\hline Fase 1: Seleção das Alternativas & Criar três alternativas de projeto de & Analista \\
& armazenagem & Analista \\
\hline $\begin{array}{c}\text { Fase 2: Construir escalas de valor para } \\
\text { os atributos }\end{array}$ & $\begin{array}{c}\text { Através de uma pesquisa de literatura } \\
\text { para escala de valores }\end{array}$ & Analista \\
\hline $\begin{array}{c}\text { Fase 3: Valorizar as alternativas } \\
\text { segundo cada atributo }\end{array}$ & $\begin{array}{c}\text { A partir das alternativas selecionadas } \\
\text { na fase 1 Utilizar o software V.I.S.A. }\end{array}$ & \\
\hline
\end{tabular}




\subsection{Etapa 3 - Aplicar o modelo em um exemplo hipotético - uso do software V.I.S.A.}

O V.I.S.A. é um programa computacional de apoio à decisão desenvolvido pela SIMUL8 Corporation (www.simul8.com/visa). Este software auxilia na construção de problemas de escolha discreta ao aplicar medidas de valor a múltiplos atributos, onde as decisões são modeladas usando uma hierarquia de funções (critérios) ponderada entre si. Uma importante característica deste software está em sua interface baseada na interação visual, permitindo aos usuários explorar em tempo real as implicações das trocas de diferentes prioridades, valores e pesos durante sua análise de sensibilidade.

Este programa foi desenvolvido com base na teoria MultiAtributed Value Theory (MAVT), que utiliza o processo de desenvolvimento denominado Multiattribute Value Function (MAVF), que é baseado na árvore de valor resultante da estruturação do problema. Para avaliar a coerência dos critérios e assertividade dos resultados desta análise multicritério foram realizadas análises de sensibilidade. 


\section{RESULTADOS}

Os resultados apresentados a seguir seguem todos os passos para a construção do modelo desta dissertação, baseado no modelo de Belton e Stewart (2002), conforme foi apresentado na metodologia.

\subsection{Etapa 1 - Identificação e estruturação do problema}

O processo de tomada de decisão se inicia com a identificação do problema. No caso desta dissertação, a decisão de investir numa instalação de armazenagem de soja em grão dá-se, principalmente, a partir de projeções futuras de aumento da safra de grãos na região (oferta), perspectivas futuras de aumento da demanda de alimento interna e mundial para os próximos anos, análise das condições atuais e de longo prazo da infraestrutura em armazenagem, além de transporte e capacidade portuária para o mesmo período. Ou seja, fatores que irão influenciar a Lei da Oferta e da Procura por armazenagem granel de soja e, a partir desta análise, descrever o comportamento preponderante dos serviços de armazenagem em determinados períodos, em função de quantidades e preços.

Como citado, já é possível observar um deficit da produção versus infraestrutura e seus reflexos podem ser medidos nos elevados custos logísticos que prejudicam a competitividade da soja brasileira no mercado internacional. Devido à importância desta cadeia na economia brasileira, justifica-se a relevância da decisão de investir em armazenagem. $O$ que falta responder é em qual projeto de armazenagem investir para satisfazer os objetivos diversos do tomador de decisão na visão de uma trading.

Os objetivos dos tomadores de decisão neste processo são: aumentar sua participação no mercado (Market Share), permitir um melhor planejamento logístico e de comercialização na procura de períodos que aumentam a sua margem de comercialização, garantindo assim, a viabilidade econômica do projeto e os resultados econômicos da empresa.

O objetivo estratégico de aumentar a sua participação numa determinada região se baseia na premissa que aumentando a sua capacidade estática aumentará sua capacidade de recebimento de soja no período crítico de colheita. Este é um fator positivo que pode aumentar o poder de compra da soja por produtores que não apresentam capacidade de armazenagem suficiente ou em regiões com déficit de armazenagem. Como se trata de commodity agrícola, a margem de 
comercialização é pequena devendo ser compensada por aumento de volume ou redução de custos.

A disponibilidade de armazenagem pela trading permite um melhor gerenciamento de toda cadeia da soja, principalmente, na diminuição de custos de transportes no período de colheita quando a demanda por caminhões é superior à oferta. Este desequilíbrio entre oferta e demanda inflaciona o mercado de frete e aumenta o custo de transporte, reduzindo ainda mais a sua margem de comercialização.

$\mathrm{O}$ produto destinado às instalações armazenadoras com sistemas eficientes de secagem e operação permitem que os grãos alcancem os padrões de qualidade exigidos no processo de exportação e que sejam mantidos por longos períodos com baixo percentual de quebra. Este atraso da venda no mercado externo pela trading pode aumentar a sua margem pela espera de melhores preços de comercialização no período de entressafra, quando historicamente, apresenta maiores cotações na bolsa de valores de Chicago (CBOT). Além disso, na entressafra a demanda por frete é menor, o que se equilibra com a oferta de caminhões e, consequentemente, o custo do frete tem tendência de queda, o que contribui para o aumento da margem de venda.

Considerando estes objetivos, a árvore da decisão (Figura18) foi construída a partir da revisão de literatura. A pesquisa baseou-se nos critérios estabelecidos na vigente Instrução da Normativa $\mathrm{N}^{\circ} 29$, a qual consolida todas as normas e procedimentos a serem adotados na implantação do Sistema Nacional de Certificação de Unidades Armazenadoras, como também de critérios e atributos utilizados em problemas de localização de instalações quando aplicável ao tema de armazenagem de soja a granel. O arranjo final e a validação foram feitos através de entrevistas com os decisores. 


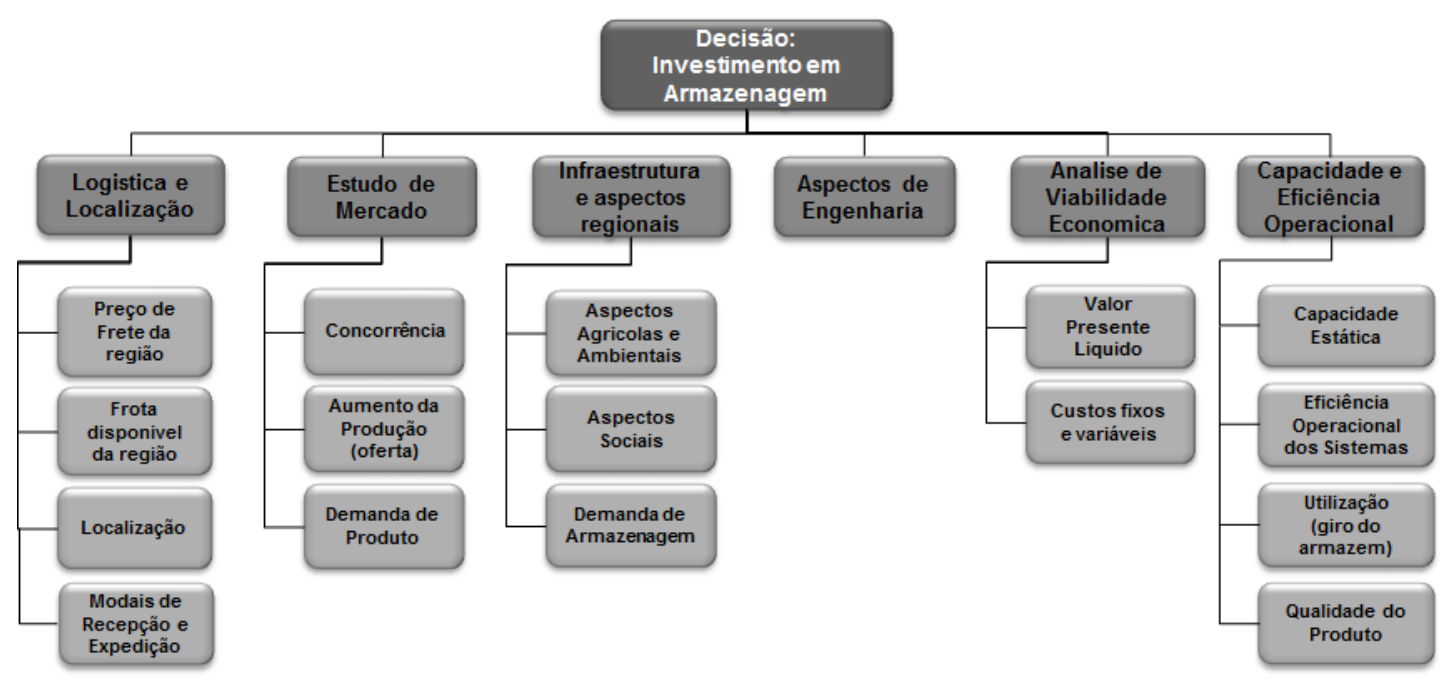

Figura 18 - Árvore de decisão desta dissertação

A partir da árvore, composta pelos critérios e respectivos atributos, foi construído o modelo multicritério como é explicado a seguir.

\subsection{Etapa 2 - Construção do Modelo Multicritério}

\subsubsection{Etapa 2 - Definição dos pesos de critérios e atributos}

Os tomadores de decisão definiram os pesos para os critérios e atributos através de suas respostas do questionário do Apêndice A, que utilizou o método AHP. Este grupo foi composto por profissionais que trabalham nas áreas que se relacionam direta ou indiretamente com uma unidade armazenadora de uma trading do setor agrícola. Os resultados, da hierarquia dos critérios definidos pelos decisores e pela decisão em grupo calculada a partir da média geométrica (método AIP), obtidos dos questionários, encontram-se no quadro 12. 


\begin{tabular}{|c|c|c|c|c|c|c|}
\hline \multirow{3}{*}{ Decisor 1} & \multicolumn{6}{|c|}{ Prioridade dos critérios para cada um dos decisores } \\
\hline & \multicolumn{5}{|l|}{ Mais Importante } & \multirow{2}{*}{$\begin{array}{c}\text { Menos Importante } \\
\text { Aspectos de } \\
\text { Engenharia }\end{array}$} \\
\hline & "Estudo de Mercado" & $\begin{array}{l}\text { Análise de } \\
\text { Viabilidade } \\
\text { Econômica }\end{array}$ & $\begin{array}{c}\text { Infraestrutura e } \\
\text { aspectos agrícolas } \\
\text { regionais }\end{array}$ & $\begin{array}{l}\text { "Localização e } \\
\text { Transporte" }\end{array}$ & $\begin{array}{l}\text { Capacidade e } \\
\text { Eficiência } \\
\text { Operacional }\end{array}$ & \\
\hline Decisor 2 & $\begin{array}{l}\text { "Localização e } \\
\text { Transporte" }\end{array}$ & "Estudo de Mercado" & $\begin{array}{c}\text { Infraestrutura e } \\
\text { aspectos agricolas } \\
\text { regionais }\end{array}$ & $\begin{array}{l}\text { Aspectos de } \\
\text { Engenharia }\end{array}$ & $\begin{array}{l}\text { Análise de } \\
\text { Viabilidade } \\
\text { Econômica }\end{array}$ & $\begin{array}{l}\text { Capacidade e } \\
\text { Eficiência } \\
\text { Operacional }\end{array}$ \\
\hline Decisor 3 & $\begin{array}{l}\text { Análise de } \\
\text { Viabilidade } \\
\text { Econômica }\end{array}$ & "Estudo de Mercado" & $\begin{array}{c}\text { "Localização e } \\
\text { Transporte" }\end{array}$ & $\begin{array}{c}\text { Infraestrutura e } \\
\text { aspectos agrícolas } \\
\text { regionais }\end{array}$ & $\begin{array}{l}\text { Capacidade e } \\
\text { Eficiência } \\
\text { Operacional }\end{array}$ & $\begin{array}{l}\text { Aspectos de } \\
\text { Engenharia }\end{array}$ \\
\hline Decisor 4 & $\begin{array}{l}\text { Capacidade e } \\
\text { Eficiência } \\
\text { Operacional }\end{array}$ & $\begin{array}{l}\text { "Localização e } \\
\text { Transporte" }\end{array}$ & $\begin{array}{c}\text { Infraestrutura e } \\
\text { aspectos agrícolas } \\
\text { regionais }\end{array}$ & "Estudo de Mercado" & $\begin{array}{l}\text { Análise de } \\
\text { Viabilidade } \\
\text { Econômica }\end{array}$ & $\begin{array}{l}\text { Aspectos de } \\
\text { Engenharia }\end{array}$ \\
\hline Decisor 5 & $\begin{array}{l}\text { Análise de } \\
\text { Viabilidade } \\
\text { Econômica }\end{array}$ & $\begin{array}{l}\text { Capacidade e } \\
\text { Eficiência } \\
\text { Operacional }\end{array}$ & $\begin{array}{c}\text { Infraestrutura e } \\
\text { aspectos agricolas } \\
\text { regionais }\end{array}$ & $\begin{array}{l}\text { "Localização e } \\
\text { Transporte" }\end{array}$ & "Estudo de Mercado" & $\begin{array}{l}\text { Aspectos de } \\
\text { Engenharia }\end{array}$ \\
\hline Decisor 6 & $\begin{array}{l}\text { "Localização e } \\
\text { Transporte" }\end{array}$ & "Estudo de Mercado" & $\begin{array}{c}\text { Infraestrutura e } \\
\text { aspectos agricolas } \\
\text { regionais }\end{array}$ & $\begin{array}{l}\text { Aspectos de } \\
\text { Engenharia }\end{array}$ & $\begin{array}{l}\text { Análise de } \\
\text { Viabilidade } \\
\text { Econômica }\end{array}$ & $\begin{array}{l}\text { Capacidade e } \\
\text { Eficiência } \\
\text { Operacional }\end{array}$ \\
\hline Decisor 7 & $\begin{array}{l}\text { Análise de } \\
\text { Viabilidade } \\
\text { Econômica }\end{array}$ & "Estudo de Mercado" & $\begin{array}{c}\text { Infraestrutura e } \\
\text { aspectos agrícolas } \\
\text { regionais }\end{array}$ & $\begin{array}{l}\text { Aspectos de } \\
\text { Engenharia }\end{array}$ & $\begin{array}{l}\text { Capacidade e } \\
\text { Eficiência } \\
\text { Operacional } \\
\end{array}$ & $\begin{array}{l}\text { "Localização e } \\
\text { Transporte" }\end{array}$ \\
\hline Decisor 8 & "Estudo de Mercado" & $\begin{array}{l}\text { Análise de } \\
\text { Viabilidade } \\
\text { Econômica }\end{array}$ & $\begin{array}{c}\text { Infraestrutura e } \\
\text { aspectos agricolas } \\
\text { regionais }\end{array}$ & $\begin{array}{l}\text { "Localização e } \\
\text { Transporte" }\end{array}$ & $\begin{array}{l}\text { Capacidade e } \\
\text { Eficiência } \\
\text { Operacional }\end{array}$ & $\begin{array}{l}\text { Aspectos de } \\
\text { Engenharia }\end{array}$ \\
\hline Decisor 9 & $\begin{array}{l}\text { "Localização e } \\
\text { Transporte" }\end{array}$ & $\begin{array}{l}\text { Análise de } \\
\text { Viabilidade } \\
\text { Econômica }\end{array}$ & $\begin{array}{c}\text { Capacidade e } \\
\text { Eficiência } \\
\text { Operacional }\end{array}$ & $\begin{array}{c}\text { Infraestrutura e } \\
\text { aspectos agricolas } \\
\text { regionais }\end{array}$ & "Estudo de Mercado" & $\begin{array}{l}\text { Aspectos de } \\
\text { Engenharia }\end{array}$ \\
\hline Decisor 10 & $\begin{array}{l}\text { "Localização e } \\
\text { Transporte" }\end{array}$ & $\begin{array}{c}\text { Infraestrutura e } \\
\text { aspectos agrícolas } \\
\text { regionais }\end{array}$ & "Estudo de Mercado" & $\begin{array}{l}\text { Análise de } \\
\text { Viabilidade } \\
\text { Econômica } \\
\end{array}$ & $\begin{array}{l}\text { Capacidade e } \\
\text { Eficiência } \\
\text { Operacional }\end{array}$ & $\begin{array}{l}\text { Aspectos de } \\
\text { Engenharia }\end{array}$ \\
\hline Decisor 11 & Estudo de Mercado & $\begin{array}{l}\text { Localização e } \\
\text { Transporte }\end{array}$ & $\begin{array}{c}\text { Infraestrutura e } \\
\text { aspectos agricolas } \\
\text { regionais }\end{array}$ & $\begin{array}{l}\text { Análise de } \\
\text { Viabilidade } \\
\text { Econômica }\end{array}$ & $\begin{array}{l}\text { Capacidadel e } \\
\text { Eficiência } \\
\text { Operacional }\end{array}$ & $\begin{array}{l}\text { Aspectos de } \\
\text { Engenharia }\end{array}$ \\
\hline $\begin{array}{c}\text { Decisão do } \\
\text { Grupo }\end{array}$ & $\begin{array}{l}\text { Análise de } \\
\text { Viabilidade } \\
\text { Econômica }\end{array}$ & $\begin{array}{l}\text { "Localização e } \\
\text { Transporte" }\end{array}$ & "Estudo de Mercado" & $\begin{array}{c}\text { Infraestrutura e } \\
\text { aspectos agrícolas } \\
\text { regionais } \\
\end{array}$ & $\begin{array}{l}\text { Capacidade e } \\
\text { Eficiência } \\
\text { Operacional }\end{array}$ & $\begin{array}{l}\text { Aspectos de } \\
\text { Engenharia }\end{array}$ \\
\hline
\end{tabular}

\section{Quadro 12 - Resultados das hierarquias por decisor}

Outra forma de mostrar os resultados de importância dos critérios é quantitativamente através dos pesos dos critérios, como mostra a Figura 19 os pesos dos critérios obtidos da decisão do grupo.

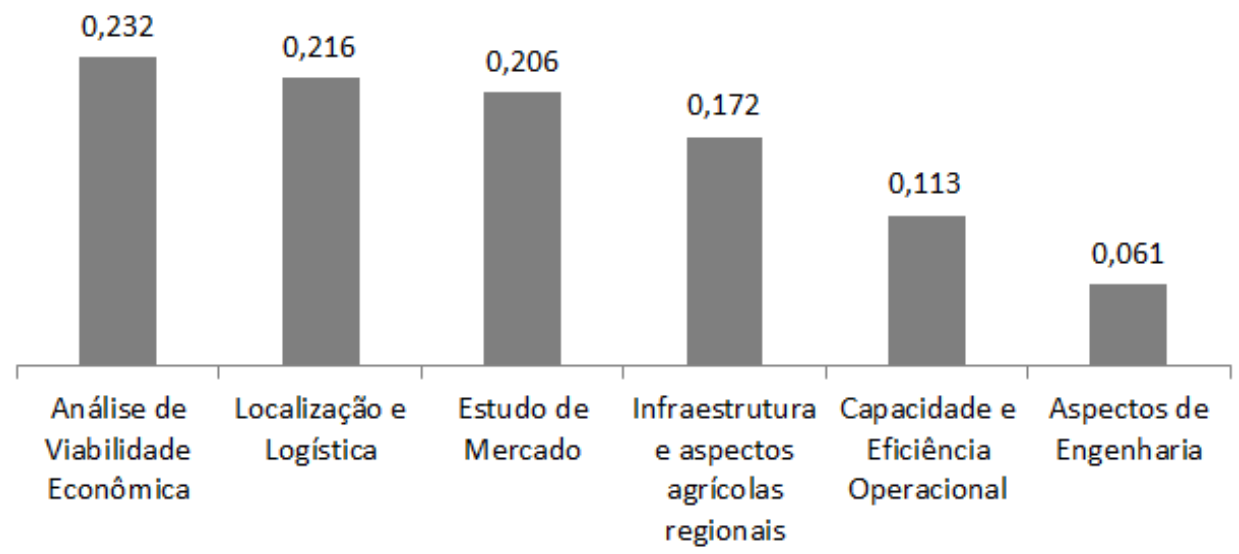

\section{Figura 19- Classificação dos decisores quanto à importância dos critérios}

A seguir encontram-se os resultados dos questionários analisados critério a critério, explicitando os conceitos e mensuração utilizados. 


\subsubsection{Localização e Transporte}

O critério "Localização e Transporte" avalia qual é o local que permitirá o melhor plano de movimentação fazenda-armazém e armazém-destino, ou seja, garantir o escoamento da maior quantidade de produto com os menores custos de transporte no tempo requerido pelo mercado, para garantir a viabilidade econômica do projeto.

O resultado na preferência do grupo coloca o critério "Localização e Transporte" na segunda posição da hierarquia de importância com o peso relativo de 0,216 . Isto significa que numa decisão de armazenagem de soja em grão, o grupo considera relevante a localização e as condições de transporte que compõem a região dos projetos estudados. Porém, observa que neste atributo alguns tomadores de decisão, chamados de “dm” (decision maker), não o consideram importante com a mesma intensidade quando comparado com os outros 5 critérios que compõem a decisão, como mostra a Figura 20, já que apresentou uma amplitude de 0,3 entre o dm02 e dm07.

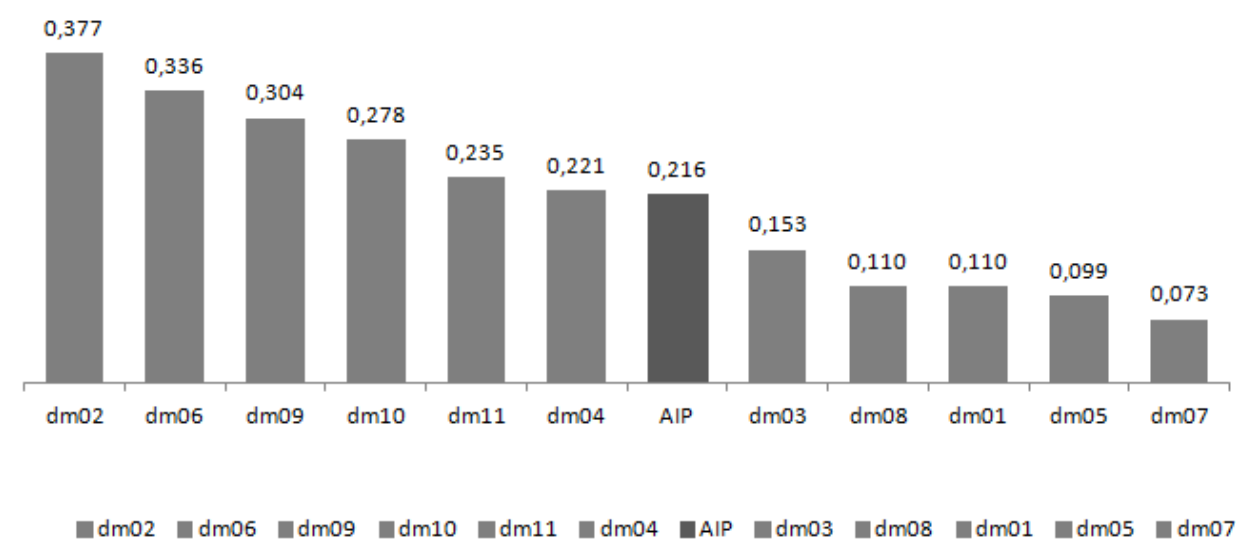

Figura 20 - Resultado dos decisores referente ao critério "localização e transporte"

Para avaliar este critério, foram selecionados quatro atributos, são eles: "localização", "preço de frete na região", "frota disponível" e "modais de recepção e expedição", como mostra o quadro 13.

\begin{tabular}{ccccc}
\hline Atributos & $\begin{array}{c}\text { Maior } \\
\text { Valor }\end{array}$ & Decisão do Grupo & $\begin{array}{c}\text { Menor } \\
\text { Valor }\end{array}$ & $\begin{array}{c}\text { Hierarquia da } \\
\text { Decisão em } \\
\text { Grupo Local }\end{array}$ \\
\hline \multirow{2}{*}{\begin{tabular}{c} 
Localização \\
\cline { 2 - 6 }
\end{tabular}} & 0,194 & 0,066 & 0,005 & $2^{\circ}$ \\
\hline $\begin{array}{c}\text { Preço de Frete da } \\
\text { Região }\end{array}$ & 0,190 & 0,075 & 0,015 & $1^{\circ}$ \\
\cline { 2 - 6 } & 0,065 & 0,048 & 0,024 & $3^{\circ}$ \\
\cline { 2 - 6 } & $\begin{array}{c}\text { Frota disponível na } \\
\text { Região }\end{array}$ & 0,028 & 0,009 & $4^{\circ}$ \\
\hline
\end{tabular}

Quadro 13 - Resultados das preferências relativas dos atributos dados pelos decisores referente ao critério "localização e transporte" 
Os resultados dos questionários mostraram que para avaliar o critério "Localização e Logística" os atributos mais importantes são "preço de frete da região" e "localização". O quadro 13 mostra que as preferências dos decisores sobre os atributos que mensuram o critério Localização e Transporte não apresentam a mesma intensidade e amplitude entre o maior e o menor peso para o atributo é grande, como pode ser visto no atributo "localização" $(0,189)$. O atributo "frota disponível na região" obteve a menor amplitude do grupo com o valor de $(0,041)$. Dessa forma, a agregação através da média geométrica proposta pelo método AIP se torna fundamental para ponderar o valor final do grupo.

\subsubsection{Estudo de Mercado}

O entendimento de como o mercado da soja se comporta, assim como possíveis fatores que podem impactar na oferta e demanda, é de extrema importância para sucesso de um projeto de armazenagem, já que a garantia de volume armazenado e margem de comercialização garantirá a viabilidade econômica da unidade armazenadora. Como já foi dito anteriormente, o destino da soja armazenada pode ser destinada tanto a uma empresa esmagadora (mercado interno) como exportação nos meses de entressafra.

O resultado na preferência do grupo coloca o critério "Estudo de Mercado" em terceiro lugar na hierarquia de importância, com o peso relativo de 0,206, como mostra a Figura 21.

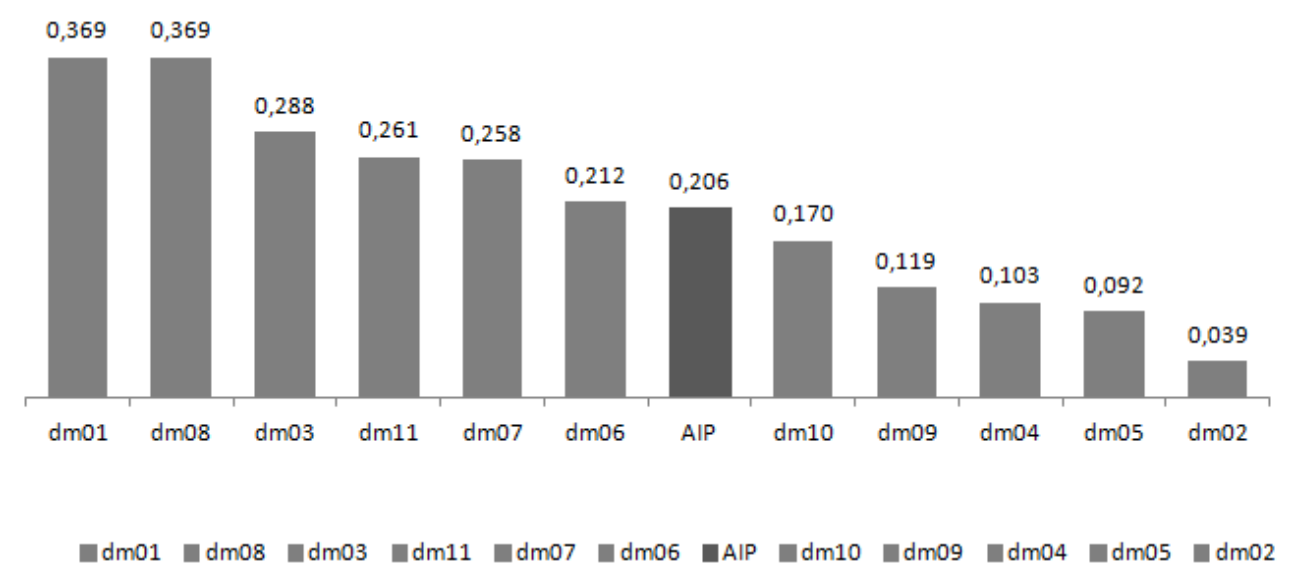

Figura 21 - Resultado dos decisores referente ao critério "Estudo de Mercado"

Apenas 0,01 do segundo critério colocado na hierarquia, o que confirma a relevância deste critério na decisão em questão. Porém, observa que neste atributo alguns tomadores de decisão não apresentaram a mesma homogeneidade no grau de preferência quando comparado 
com os outros 5 critérios que compõem a decisão Pois, apresentou uma amplitude de 0,33 na opinião entre os tomadores de decisão dm02 e dm01.Para avaliar este critério foram selecionados três atributos, são eles: "concorrência", "aumento da produção" e "demanda de produto". Os resultados dos questionários mostraram que para avaliar o critério "Estudo do Mercado" os atributos mais importantes são "concorrência" e "demanda de produto", como mostra o quadro 14.

\begin{tabular}{|c|c|c|c|c|c|}
\hline & Atributos & Maior Valor & $\begin{array}{c}\text { Decisão } \\
\text { do Grupo }\end{array}$ & $\begin{array}{l}\text { Menor } \\
\text { Valor }\end{array}$ & $\begin{array}{c}\text { Hierarquia da } \\
\text { Decisão em } \\
\text { Grupo Local }\end{array}$ \\
\hline \multirow{3}{*}{ 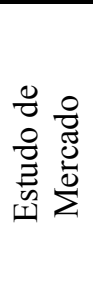 } & $\begin{array}{l}\text { Concorrência } \\
\text { (aumento de } \\
\text { Market Share) }\end{array}$ & 0,169 & 0,080 & 0,021 & $1^{\mathrm{o}}$ \\
\hline & $\begin{array}{c}\text { Aumento da } \\
\text { Produção (Oferta) }\end{array}$ & 0,124 & 0,047 & 0,006 & $3^{\circ}$ \\
\hline & $\begin{array}{l}\text { Demanda de } \\
\text { Produto }\end{array}$ & 0,139 & 0,078 & 0,012 & $2^{\circ}$ \\
\hline
\end{tabular}

\section{Quadro 14- Resultados das preferências relativas dos atributos dados pelos decisores} referente ao critério "Estudo de Mercado"

O quadro 14 mostra que as preferências dos decisores sobre os atributos que mensuram o critério "Estudo de Mercado" também não apresentaram a mesma homogeneidade no grau de preferência, bem como as amplitudes entre o maior e o menor peso para o mesmo atributo são superiores a 0,1 nos três atributos. Dessa forma, a agregação através da média geométrica proposta pelo método AIP se torna fundamental para ponderar o valor final do grupo.

\subsubsection{Infraestrutura e aspectos regionais}

O critério "infraestrutura e aspectos regionais" avalia a região na qual serão alocados os projetos em estudo sob três principais aspectos: agrícolas, sociais e, sobre o tema deste estudo, a demanda por armazenagem. O atributo "aspectos agrícolas" avalia qualitativamente as condições de clima, solo, lavouras plantadas e áreas férteis disponíveis, enquanto o atributo "demanda por armazenagem" avalia a demanda por armazenagem a granel da região. E por fim, o atributo "aspectos sociais" caracteriza a mão de obra especializada disponível e a presença de escolas, hospitais, transportes e lazer, que garantirão a bom gerenciamento da unidade.

A preferência do grupo em relação ao critério "infraestrutura e aspectos regionais" é moderada em relação aos outros 5 critérios, já que sua colocação na hierarquia é quarto lugar com o peso relativo 0,172 , como mostra a Figura 22. Porém, observa-se que neste quesito os 
tomadores de decisão apresentam mais homogeneidade no grau de importância, já que apresentou uma amplitude de 0,119 na opinião entre os tomadores de decisão dm11 e dm03.

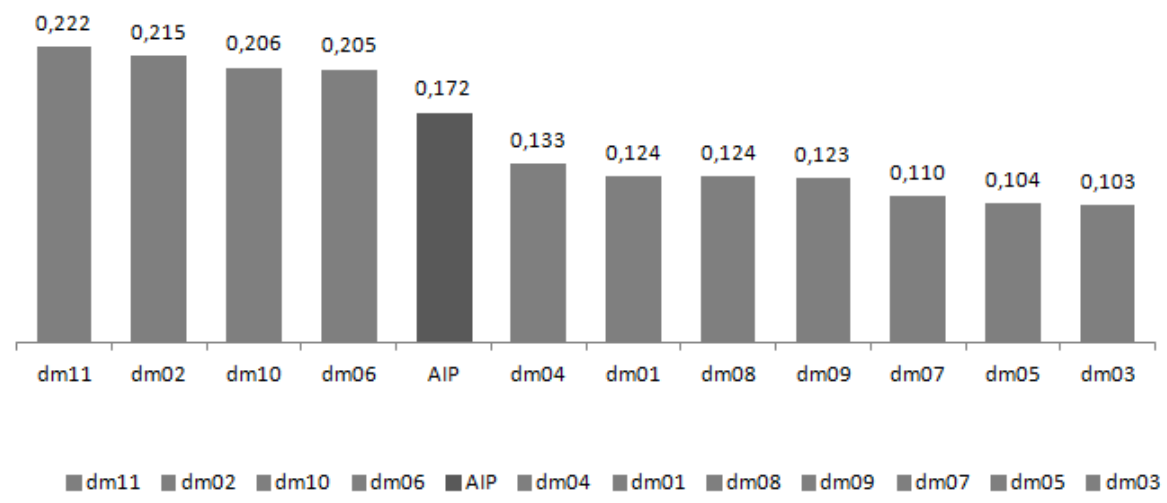

Figura 22 - Comportamento dos pesos referente ao critério "Infraestrutura e aspectos agrícolas regionais"

Os resultados dos questionários mostraram que para avaliar este critério os atributos mais importantes são "demanda de armazenagem" e "aspectos agrícolas e ambientais", como mostra o quadro 15.

\begin{tabular}{|c|c|c|c|c|c|}
\hline & Atributos & $\begin{array}{l}\text { Maior } \\
\text { Valor }\end{array}$ & $\begin{array}{l}\text { Decisão do } \\
\text { Grupo }\end{array}$ & $\begin{array}{l}\text { Menor } \\
\text { Valor }\end{array}$ & $\begin{array}{c}\text { Hierarquia da } \\
\text { Decisão em } \\
\text { Grupo Local }\end{array}$ \\
\hline \multirow{3}{*}{ 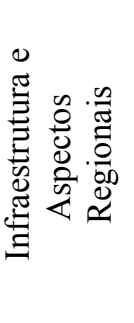 } & $\begin{array}{l}\text { Aspectos } \\
\text { Agrícolas e } \\
\text { Ambientais }\end{array}$ & 0,110 & 0,061 & 0,010 & $2^{\circ}$ \\
\hline & $\begin{array}{c}\text { Demanda de } \\
\text { Armazenagem }\end{array}$ & 0,167 & 0,081 & 0,020 & $1^{\mathrm{o}}$ \\
\hline & $\begin{array}{l}\text { Aspectos } \\
\text { Sociais }\end{array}$ & 0,077 & 0,030 & 0,008 & $3^{\circ}$ \\
\hline
\end{tabular}

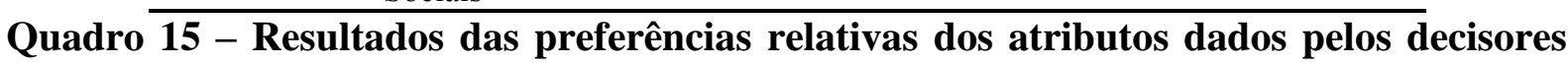
referente ao critério "infraestrutura e aspectos regionais"

O quadro 15 mostra que as preferências dos decisores sobre os atributos que mensuram o critério "Infraestrutura e Aspectos Regionais" também se mostram heterogêneos quanto à intensidade, já que as amplitudes entre o maior e o menor peso para o mesmo atributo são elevadas, como pode ser visto no atributo "demanda de armazenagem" $(0,147)$. O atributo "aspectos sociais" obteve a menor amplitude do grupo com o valor de $(0,069)$. Dessa forma, a agregação através da média geométrica proposta pelo método AIP se torna fundamental para ponderar o valor final do grupo. 


\subsubsection{Análise de Viabilidade Econômica}

O atributo "Análise de Viabilidade Econômica" refere-se à avaliação ou estudo da viabilidade, estabilidade e lucratividade do projeto. No caso deste trabalho, engloba dois atributos: "VPL" e "Custos" que permitem realizar diagnósticos sobre a situação financeira do projeto, assim como prognósticos sobre o seu desempenho futuro.

O resultado da preferência do grupo pelo critério "Análise de Viabilidade Econômica" mostra a elevada relevância desta avaliação na decisão. É o critério que se encontra no topo da distribuição hierárquica com o peso relativo de 0,232, como mostra a Figura 23. Porém, a amplitude dos pesos entre os decisores foi a maior encontrada com o valor de 0,440 , o que confirma a heterogeneidade do grupo.

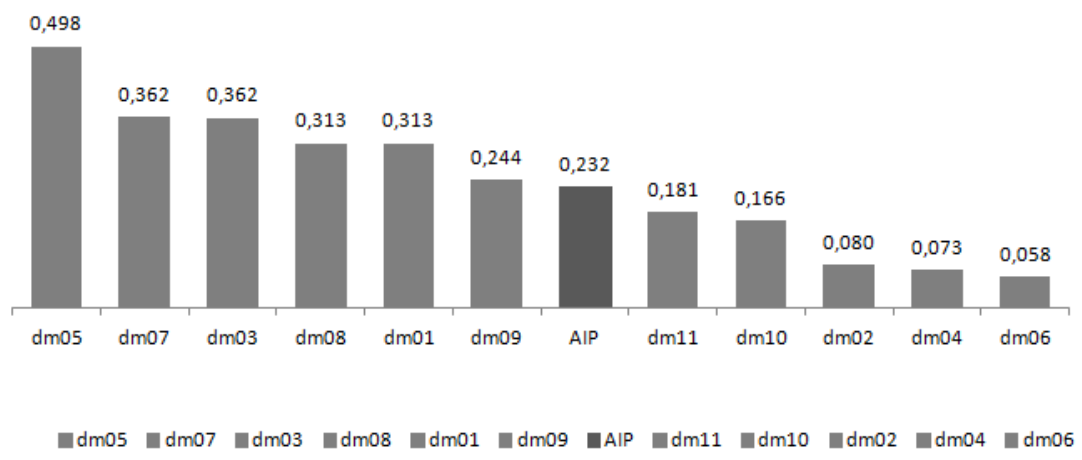

Figura 23 - Resultado dos decisores referente ao critério "Análise de Viabilidade Econômica"

Os resultados dos questionários mostraram que para avaliar este critério, o grupo considera "VPL" mais importante que o atributo "qualificação dos custos fixos e variáveis", como mostra o quadro 16.

\begin{tabular}{|c|c|c|c|c|c|}
\hline & Atributos & $\begin{array}{l}\text { Maior } \\
\text { Valor }\end{array}$ & $\begin{array}{c}\text { Decisão } \\
\text { do Grupo }\end{array}$ & $\begin{array}{l}\text { Menor } \\
\text { Valor }\end{array}$ & $\begin{array}{l}\text { Hierarquia da } \\
\text { Decisão em } \\
\text { Grupo Local } \\
\end{array}$ \\
\hline \multirow{2}{*}{ 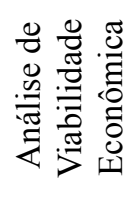 } & Valor Presente Líquido & 0,289 & 0,172 & 0,040 & $1^{\mathrm{o}}$ \\
\hline & $\begin{array}{c}\text { Qualificação e } \\
\text { Quantificação dos } \\
\text { Custos Fixos e Variáveis }\end{array}$ & 0,249 & 0,060 & 0,007 & $2^{\circ}$ \\
\hline
\end{tabular}

Quadro 16- Resultados das preferências relativas dos atributos dados pelos decisores referente ao critério "análise de viabilidade econômica" 
$\mathrm{O}$ quadro 16 mostra que as preferências dos decisores sobre os atributos que mensuram o critério "Análise de Viabilidade Econômica" também se mostram heterogêneos quanto à intensidade e apresentam as maiores amplitudes entre o maior e o menor peso para o mesmo atributo, sendo seus valores 0,249 para o "VPL" e 0,242 para "quantificação e qualificação dos custos fixos e variáveis". Mais uma vez, verifica-se a importância da utilização do método de agregação das respostas individuais para ponderar o valor final do grupo.

\subsubsection{Aspectos de engenharia}

O critério "Aspectos de engenharia" foi baseado na Instrução Normativa $N^{o}$ 29, de 8 junho de 2011, que consolida todas as normas e procedimentos a serem adotados na implantação do Sistema Nacional de Certificação de Unidades Armazenadoras. Este documento estabelece os requisitos técnicos obrigatórios ou recomendados para construção, instalação e funcionamento de estruturas de armazenamento visando a modernização do setor, como mostrado anteriormente no quadro 9.

O resultado na preferência do grupo coloca o critério "Aspectos de Engenharia” em último lugar na hierarquia de importância, com o peso relativo de 0,061, como mostra a Figura 24. O critério "Aspectos de engenharia" não tem atributo vinculado.

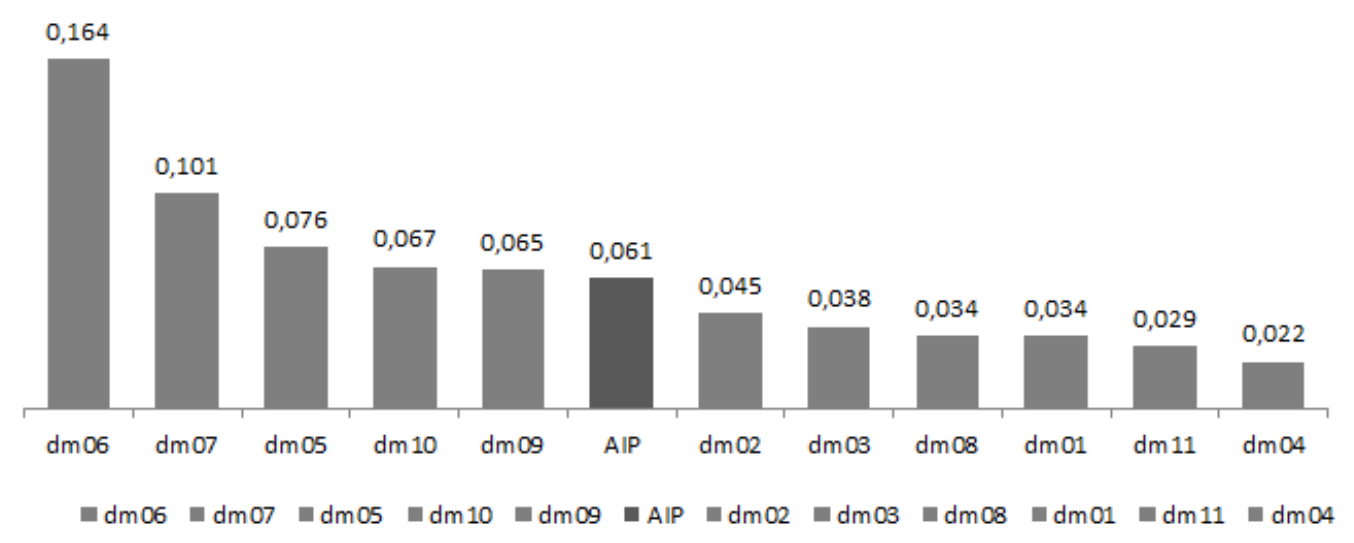

Figura 24 - Resultado dos decisores referente ao critério "Aspectos de engenharia"

\subsubsection{Capacidade e eficiência operacional}

O critério "Capacidade e eficiência operacional" mede o potencial do projeto em garantir o alcance do objetivo do armazenamento que é guardar e preservar as características que os grãos apresentam após a colheita, diminuindo ao máximo as perdas, utilizando-se, da melhor maneira possível, a capacidade e as técnicas existentes. 
O resultado na preferência do grupo coloca o critério "Capacidade e Eficiência Operacional" em quinto (ou penúltimo) lugar na hierarquia de importância, com o peso relativo de 0,113. Os tomadores de decisão não reconhecem a relevância em comparação com os outros critérios. Porém, nota-se que os tomadores de decisão não apresentam homogeneidade no grau de preferência, apresentando uma amplitude de 0,422 na opinião entre os tomadores de decisão dm04 e dm06, como mostra a Figura 25.

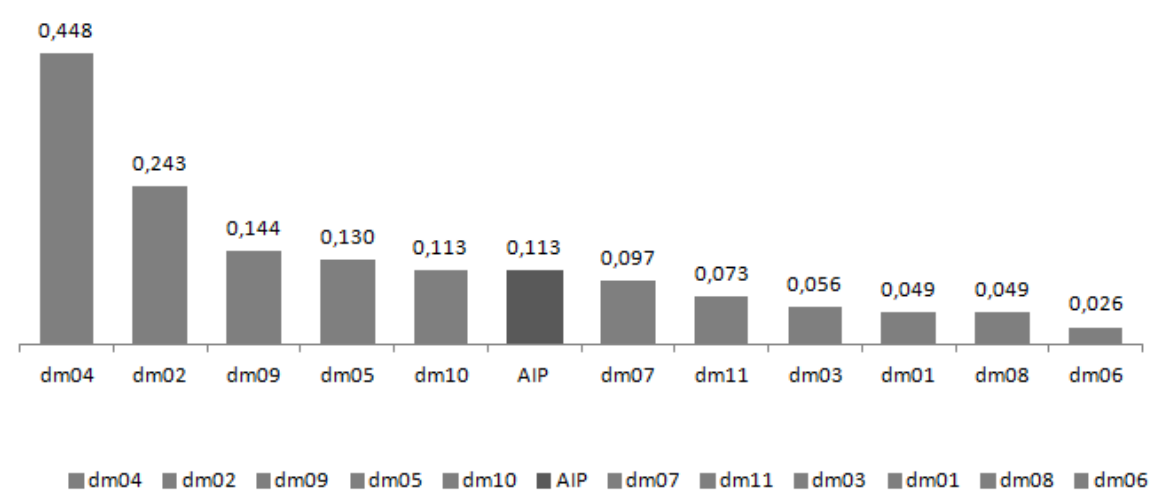

Figura 25 - Resultado dos decisores referente ao critério "Capacidade e Eficiência Operacional"

Os atributos selecionados para medir o critério "capacidade e eficiência operacional" foram: “capacidade estática", "utilização (giros de armazém)", "eficiência dos sistemas e linhas de processamento" e "qualidade do produto". Os resultados dos questionários mostraram que para avaliar este critério, os atributos mais importantes são "eficiência dos sistemas e linhas de processamento" e "utilização (giros de armazém)", como mostra o quadro 17.

\begin{tabular}{|c|c|c|c|c|c|}
\hline & Atributos & $\begin{array}{l}\text { Maior } \\
\text { Valor }\end{array}$ & $\begin{array}{l}\text { Decisão do } \\
\text { Grupo }\end{array}$ & $\begin{array}{l}\text { Menor } \\
\text { Valor }\end{array}$ & $\begin{array}{c}\text { Hierarquia da } \\
\text { Decisão em } \\
\text { Grupo Local }\end{array}$ \\
\hline \multirow{4}{*}{ 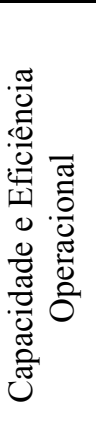 } & $\begin{array}{c}\text { Capacidade } \\
\text { Estática } \\
\end{array}$ & 0,083 & 0,028 & 0,008 & $3^{\circ}$ \\
\hline & $\begin{array}{c}\text { Eficiência dos } \\
\text { sistemas e } \\
\text { linhas de } \\
\text { processamento }\end{array}$ & 0,254 & 0,034 & 0,001 & $1^{\mathrm{o}}$ \\
\hline & $\begin{array}{c}\text { Utilização } \\
\text { (Giros de } \\
\text { Armazém) }\end{array}$ & 0,100 & 0,030 & 0,006 & $2^{\circ}$ \\
\hline & $\begin{array}{l}\text { Qualidade do } \\
\text { Produto }\end{array}$ & 0,095 & 0,021 & 0,004 & $4^{o}$ \\
\hline
\end{tabular}

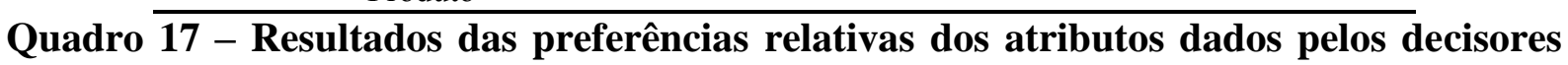
referente ao critério "Capacidade e Eficiência Operacional" 
$\mathrm{O}$ quadro 17 mostra que as preferências dos decisores sobre os atributos que mensuram o critério "Infraestrutura e Aspectos Regionais" também se mostram heterogêneos quanto à intensidade, já que as amplitudes entre o maior e o menor peso para o mesmo atributo são elevadas, como pode ser visto no atributo "eficiência dos sistemas e linhas de processamento" $(0,251)$. O atributo "capacidade estática" obteve a menor amplitude do grupo com o valor de $(0,075)$. Dessa forma, a agregação através da média geométrica proposta pelo método AIP se torna fundamental para ponderar o valor final do grupo.

\subsubsection{Hierarquia global dos atributos}

A hierarquia global dos atributos distribui as posições dos atributos levando em consideração todos os atributos da árvore de decisão e não somente do critério que os abrangem. (quadro $18)$.

\begin{tabular}{|c|c|c|c|c|c|}
\hline & Atributos & $\begin{array}{l}\text { Maior } \\
\text { Valor }\end{array}$ & $\begin{array}{l}\text { Decisão do } \\
\text { Grupo }\end{array}$ & $\begin{array}{l}\text { Menor } \\
\text { Valor }\end{array}$ & $\begin{array}{l}\text { Hierarquia } \\
\text { da Decisão } \\
\text { em Grupo }\end{array}$ \\
\hline \multirow{4}{*}{ 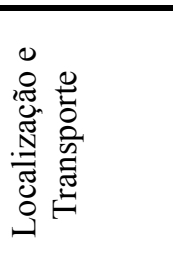 } & Localização & 0,194 & 0,66 & 0,005 & $6^{\circ}$ \\
\hline & Preço de Frete da Região & 0,190 & 0,075 & 0,015 & $5^{\circ}$ \\
\hline & $\begin{array}{c}\text { Frota disponível na } \\
\text { Região }\end{array}$ & 0,065 & 0,048 & 0,024 & $10^{\circ}$ \\
\hline & $\begin{array}{l}\text { Modais de Recepção e } \\
\text { Expedição }\end{array}$ & 0,093 & 0,028 & 0,009 & $15^{\circ}$ \\
\hline \multirow{3}{*}{ 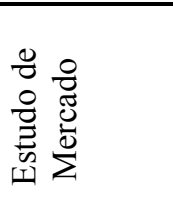 } & $\begin{array}{l}\text { Concorrência (aumento } \\
\text { de Market Share) }\end{array}$ & 0,169 & 0,080 & 0,021 & $3^{\circ}$ \\
\hline & $\begin{array}{c}\text { Aumento da Produção } \\
\text { (Oferta) }\end{array}$ & 0,124 & 0,047 & 0,006 & $11^{\circ}$ \\
\hline & Demanda de Produto & 0,139 & 0,078 & 0,012 & $4^{\circ}$ \\
\hline \multirow{3}{*}{ 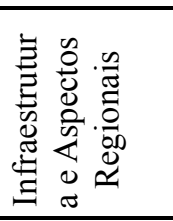 } & $\begin{array}{c}\text { Aspectos Agrícolas e } \\
\text { Ambientais }\end{array}$ & 0,110 & 0,061 & 0,010 & $7^{\circ}$ \\
\hline & $\begin{array}{c}\text { Demanda de } \\
\text { Armazenagem }\end{array}$ & 0,167 & 0,081 & 0,020 & $2^{\circ}$ \\
\hline & Aspectos Sociais & 0,077 & 0,030 & 0,008 & $14^{\circ}$ \\
\hline 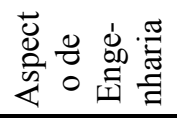 & Aspecto de Engenharia & 0,164 & 0,061 & 0,022 & $8^{\circ}$ \\
\hline \multirow{2}{*}{ 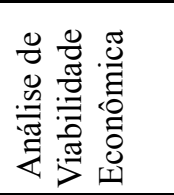 } & Valor Presente Líquido & 0,289 & 0,172 & 0,040 & $1^{\circ}$ \\
\hline & $\begin{array}{c}\text { Qualificação e } \\
\text { Quantificação dos Custos } \\
\text { Fixos e Variáveis }\end{array}$ & 0,249 & 0,060 & 0,007 & $9^{\circ}$ \\
\hline \multirow{4}{*}{ 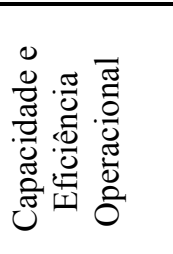 } & Capacidade Estática & 0,083 & 0,028 & 0,008 & $16^{\circ}$ \\
\hline & $\begin{array}{l}\text { Eficiência dos sistemas e } \\
\text { linhas de processamento }\end{array}$ & 0,254 & 0,034 & 0,001 & $12^{\circ}$ \\
\hline & $\begin{array}{l}\text { Utilização (Giros de } \\
\text { Armazém) }\end{array}$ & 0,100 & 0,030 & 0,006 & $13^{\circ}$ \\
\hline & Qualidade do Produto & 0,095 & 0,021 & 0,004 & $17^{\circ}$ \\
\hline
\end{tabular}


O quadro 18 mostra que os cinco atributos mais importantes da decisão de investir em uma unidade de armazenagem em grão são: "VPL", "demanda de armazenagem”, "concorrência"; "demanda de produto" e "preço de frete da região".

Esse resultado sugere que os atributos mais relevantes se referem à perspectiva de aumento de mercado e preocupação com a diminuição de custos logísticos. A relevância de critérios de mercado e relacionados à logística corrobora a literatura na medida em que evidencia a importância de melhorias de infraestrutura logística para escoamento e armazenagem dos grãos frente às projeções otimistas de aumento de safra.

Em contrapartida, observa-se que os atributos "Qualidade" e "Capacidade estática" foram os menos relevantes. Como se trata de uma commodity agrícola, ou seja, de um produto padronizado e com especificações bem definidas, qualidade acima das especificações não são premiadas financeiramente o que pode explicar a menor relevância em relação aos outros critérios. A necessidade de manter este critério na análise se deve ao fato que penalidades são realizadas para produtos que não atendem as especificações. Estas penalidades podem reduzir margens.

Já em relação à capacidade estática, o aumento de capacidade de armazenagem por si só, sem o acompanhamento de um eficiente gerenciamento das operações e da logística não garante a viabilidade do projeto e o aumento de margens comerciais. O sucesso do investimento e seu retorno dependem de inúmeros outros fatores, o que pode explicar a menor relevância deste critério e que reforça a relevância de uma análise multicritério para decisões de armazenagem granel de grãos.

\subsubsection{Teste de Consistência}

Analisando os resultados dos pesos dados pelos tomadores de decisão também é possível notar elevadas amplitudes entre os pesos obtidos, o que revela opiniões divergentes sobre um mesmo critério do grupo. Esta falta de entrosamento do grupo tem seus efeitos minimizados pelo método de Agregação Individual de Prioridades (AIP), como já explicado anteriormente, que visa sintetizar cada uma das hierarquias individuais através de uma média geométrica das prioridades resultantes. Sem um método específico no processo de tomada de decisão, dificilmente o grupo chegaria num consenso e resultados consistentes.

Como as preferências foram obtidas através do método AHP, teste de consistência se faz necessário para garantir a consistência da decisão. A Figura 26 apresenta os resultados obtidos 
deste teste para os critérios da decisão em grupo, o que mostra que as preferências obtidas são consistentes, já que obteve o valor de 0,4 para uma referência máxima de 1,24, no caso de 6 critérios.

\begin{tabular}{|c|c|c|c|c|}
\hline CRITÉRIO & Prioridade Relativa & Vetor de Pesos & Vetor de Consistência & Teste de Consistência \\
\hline "Localização e Transportes" & 0,218 & 1,37 & 6,30 & \multirow{6}{*}{$\begin{array}{c}\text { Para } 6 \text { critérios, o valor } \\
\text { obtido no teste não deve } \\
\text { ser superior a sua } \\
\text { referência de } 1,24 \\
\text { (Fonte: Shimizu, 2006) }\end{array}$} \\
\hline "Estudo de Mercado" & 0,213 & 1,33 & 6,27 & \\
\hline $\begin{array}{l}\text { Infraestrutura e aspectos } \\
\text { agrícolas regionais }\end{array}$ & 0,173 & 1,07 & 6,19 & \\
\hline Aspectos de Engenharia & 0,058 & 0,36 & 6,14 & \\
\hline $\begin{array}{c}\text { Análise de Viabilidade } \\
\text { Econômica }\end{array}$ & 0,228 & 1,42 & 6,23 & \\
\hline \multirow[t]{2}{*}{$\begin{array}{c}\text { Capacidade e Eficiência } \\
\text { Operacional }\end{array}$} & 0,109 & 0,68 & 6,24 & \\
\hline & & Média & 6,23 & 0,04 \\
\hline
\end{tabular}

\section{Figura 26 - Resultados do Teste de Consistência para os critérios}

O mesmo teste foi aplicado para os atributos de cada critério e todos se mostraram coerentes para as suas referências, de acordo com o número de atributos em questão.

\subsubsection{Etapa 2 - Definição das escalas de valor dos atributos}

\subsubsection{Localização e Transporte}

Para avaliar este critério foram selecionados quatro atributos: "localização", "preço de frete na região", "frota disponível” e "modais de recepção e expedição".

Localização: Este atributo é do tipo construído com faixa de prioridade do tipo local, levando somente em consideração a localização predefinida das alternativas existentes. A escala de valor terá como valor 100 a localização com menor distância média dos principais pontos relevantes a decisão (melhor cenário) e valor 0 a localização com mais distante (pior cenário), sendo a unidade de medida quilômetros.

Preço de frete da região: Este atributo é do tipo natural com faixa de prioridade do tipo local, ou seja, a escala de valor que medirá tal atributo utilizará como valor 100 o projeto com 
menor frete médio (melhor cenário) e valor 0 a alternativa com maior frete (pior cenário), a unidade de medida de frete será $\mathrm{R} \$ / \mathrm{km}$.

Frota: Este atributo é do tipo natural com faixa de prioridade do tipo local, ou seja, a escala de valor que medirá tal atributo utilizará como valor 100 o projeto com maior número de caminhões (melhor cenário) e valor 0 a alternativa com a menor frota disponível (pior cenário), a unidade de medida de frete será de baixo á alto (disponibilidade).

Modais de recepção e expedição: Este atributo é do tipo construído com faixa de prioridade do tipo local, ou seja, a escala de valor que medirá tal atributo utilizará como valor $100 \mathrm{o}$ projeto com a disponibilidade de utilizar os modais mais eficientes (mais econômicos e que permitam o escoamento de maiores volumes - melhor cenário) e valor 0 os modais menos eficientes (pior cenário).

\subsubsection{Estudo de Mercado}

Para avaliar este critério foram selecionados três atributos são eles: "concorrência", "aumento da produção" e "demanda de produto" que foram valorizados, como explicados a seguir.

Concorrência: atributo é do tipo construído com faixa de prioridade do tipo local, tendo a escala de valor qualitativa e terá maior valor o projeto que apresentar o mercado com as melhores condições de crescimento de participação (Market share) e de obtenção de maiores margens de comercialização. Enquanto, o projeto que estiver inserido num mercado muito competitivo com margens de comercialização receberá o menor valor da escala, pois dificultará a viabilidade econômica do projeto.

Tanto o atributo "aumento da produção" quanto "demanda do produto" é do tipo natural e com faixa de prioridade do tipo local, considerando a projeção de crescimento de produção na região, atribuído ao indicador quantitativo que considera quanto maior o percentual de aumento melhor. 


\subsubsection{Infraestrutura e aspectos regionais}

O critério "infraestrutura e aspectos regionais" avalia a região na qual serão alocados os projetos em estudo sob três principais aspectos: agrícolas, sociais e, tema deste estudo, a demanda por armazenagem.

Aspectos Agrícolas: atributo do tipo construído e com faixa de prioridade do tipo local, mede qualitativamente as condições de clima, solo, lavouras plantadas e áreas férteis disponíveis, quanto melhor essas condições, mais alto o valor.

Demanda por armazenagem: é do tipo natural com faixa de prioridade do tipo local que estabelece com base nas características dos produtos, qual a demanda por armazenagem a granel da região. Trata-se de uma escala quantitativa que considera quanto maior o percentual de aumento melhor

Aspectos Sociais: atributo do tipo construído com faixa de prioridade do tipo local e considera qualitativamente a mão de obra especializada disponível e a presença de escolas, hospitais, transportes e lazer, quanto mais alto valor, melhor.

\subsubsection{Análise de Viabilidade Econômica}

O critério "Análise de Viabilidade Econômica" avalia os projetos quanto ao seu sucesso financeiro sob dois atributos: "VPL" e "Custos".

Valor Presente Líquido (VPL): atributo do tipo construído com faixa de prioridade do tipo local e representa o potencial de ganho que poderá ser conquistado pela implementação de uma instalação de armazenagem, terá caráter qualitativo, pois será acompanhado de uma avaliação subjetiva de cada projeto, seguido a referência de alto (VPL maior que 0) e baixo (valor igual a 0 ).

Qualificação e Quantificação dos Custos Fixos e Variáveis: atributo do tipo natural com faixa de prioridade local, considerando a quantificação de todos os custos envolvidos e encargos financeiros durante o período de carência, rentabilidade e capacidade de pagamento para compor a análise do retorno financeiro. A unidade de medida será em $\mathrm{R} \$ /$ ton e sua preferência será quanto menor valor, melhor. 


\subsubsection{Aspectos de engenharia}

O critério "Aspectos de engenharia" não tem atributo vinculado, portanto a escala de valor é feita diretamente ao critério. É classificado como construído com faixa de prioridade do tipo local, levando somente em consideração as características qualitativas sobre o projeto de engenharia predefinido das alternativas existentes. A escala de valor terá como valor $100 \mathrm{o}$ projeto que melhor atende a Instrução Normativa 29, ou seja, que garanta a certificação dos itens obrigatórios e recomendados, valor 50 (médio) o projeto que garanta a certificação obedecendo somente os itens obrigatórios e valor 0 o projeto que não atende plenamente as especificações da Normativa.

\subsubsection{Capacidade e eficiência operacional}

Os atributos selecionados para medir o critério "capacidade e eficiência operacional" foram: “capacidade estática", "utilização (giros de armazém)", "eficiência dos sistemas e linhas de processamento" e "qualidade do produto".

Capacidade estática: é atributo natural com faixa de prioridade local. É definida como a quantidade de grãos que cabe de uma só vez confinada em uma unidade armazenadora (em toneladas), sendo o maior valor referente ao melhor cenário.

Eficiência dos sistemas e linhas de processamento: atributo construído com faixa de prioridade do tipo local, com análise qualitativa (quanto mais alto melhor). O melhor projeto receberá o valor 100, enquanto o projeto menos eficiente receberá o valor zero.

Utilização (giros de armazém): atributo natural com faixa de prioridade do tipo local, sua unidade de medida será em "giros de armazém" calculada pela quantidade de grãos que entrou e saiu de uma unidade armazenadora no período de um ano (capacidade dinâmica) divido pela capacidade do armazém. Sua análise é quantitativa com preferência do maior valor.

Qualidade do produto: atributo construído com faixa de prioridade local, que avalia qualitativamente as características do produto durante o período de armazenamento (quanto mais alto, melhor). 


\subsubsection{Resumo dos Critérios}

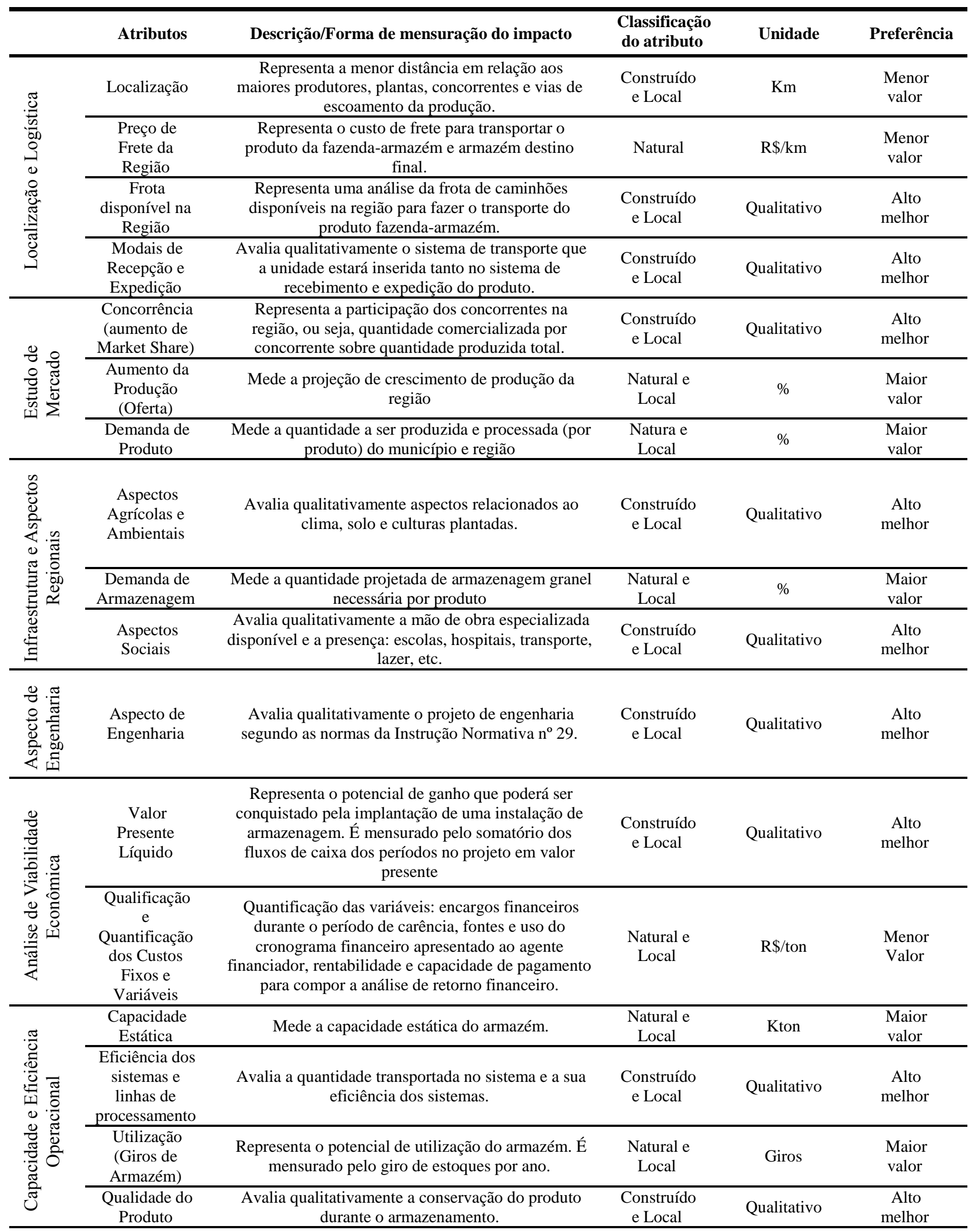


O quadro 19 resume os atributos utilizados na construção de modelo e apresenta sua classificação quanto ao tipo: natural, proxy e construído. Observa-se que a maioria dos atributos é do tipo construído. Isto se deve à impossibilidade ou inexistência de obter mensurações diretas, sendo assim foi necessário que se desenvolvesse uma mensuração capaz de medir indiretamente o objetivo.

\subsubsection{Valoração das Alternativas}

A escala de valor utilizada para avaliar as alternativas foi do tipo local, ou seja, o projeto que apresentar o melhor desempenho em um determinado critério é o que assumirá o valor 100 da escala e o pior desempenho será posicionado no ponto 0 . Como apresentado no quadro 17 , esta decisão foi composta de atributos quantitativos e qualitativos. Os atributos qualitativos

para simplificar assumiram escalas lineares. Já os atributos qualitativos foram avaliados por escala de valor de três níveis, onde o valor 100 é o alto, 50 é o médio e 0 o valor baixo. A definição foi feita pelo analista, fato este que pode ser considerado como uma limitação desta pesquisa por não ter as preferências dos decisores nesta etapa. 


\begin{tabular}{|c|c|c|c|c|c|c|c|}
\hline & Atributos & $\begin{array}{l}\text { Unidade de } \\
\text { medida }\end{array}$ & Projeto A & $\begin{array}{c}\text { Projeto } \\
\text { B }\end{array}$ & $\begin{array}{c}\text { Projeto } \\
\text { C }\end{array}$ & $\begin{array}{c}\text { Escala } \\
\text { de Valor }\end{array}$ & Preferência \\
\hline \multirow{4}{*}{ 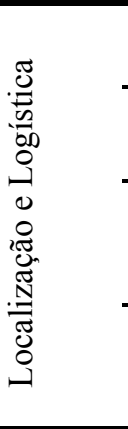 } & Localização & $\mathrm{Km}$ & 100 & 200 & 300 & $\begin{array}{c}100 \mathrm{a} \\
300\end{array}$ & menor valor \\
\hline & $\begin{array}{l}\text { Preço de Frete } \\
\text { da Região }\end{array}$ & $\mathrm{R} \$ / \mathrm{km}$ & 5,70 & 5,40 & 4,60 & $\begin{array}{c}4,60 \mathrm{a} \\
5,70\end{array}$ & menor valor \\
\hline & $\begin{array}{c}\text { Frota } \\
\text { disponível na } \\
\text { Região } \\
\end{array}$ & qualitativo & baixo & médio & alto & $\begin{array}{l}\text { baixo a } \\
\text { alto }\end{array}$ & alto melhor \\
\hline & $\begin{array}{l}\text { Modais de } \\
\text { Recepção e } \\
\text { Expedição }\end{array}$ & qualitativo & baixo & médio & alto & $\begin{array}{l}\text { baixo a } \\
\text { alto }\end{array}$ & alto melhor \\
\hline \multirow{3}{*}{ 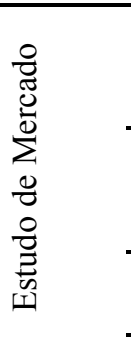 } & $\begin{array}{l}\text { Concorrência } \\
\text { (aumento } \\
\text { market share) }\end{array}$ & qualitativo & Alto & médio & baixo & $\begin{array}{l}\text { baixo a } \\
\text { alto }\end{array}$ & alto melhor \\
\hline & $\begin{array}{l}\text { Aumento da } \\
\text { Produção } \\
\text { (Oferta) }\end{array}$ & $\%$ & 15 & 5 & 10 & 5 a 15 & maior valor \\
\hline & $\begin{array}{l}\text { Demanda de } \\
\text { Produto }\end{array}$ & $\%$ & 15 & 5 & 10 & 5 a 15 & maior valor \\
\hline \multirow{3}{*}{ 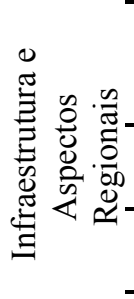 } & $\begin{array}{c}\text { Aspectos } \\
\text { Agrícolas e } \\
\text { Ambientais }\end{array}$ & qualitativo & Alto & baixo & alto & $\begin{array}{l}\text { baixo a } \\
\text { alto }\end{array}$ & alto melhor \\
\hline & $\begin{array}{c}\text { Demanda de } \\
\text { Armazenagem }\end{array}$ & $\%$ & 20 & 15 & 15 & 15 a 20 & maior valor \\
\hline & $\begin{array}{c}\text { Aspectos } \\
\text { Sociais } \\
\end{array}$ & qualitativo & baixo & médio & alto & $\begin{array}{c}\text { baixo a } \\
\text { alto }\end{array}$ & alto melhor \\
\hline \multirow[t]{2}{*}{ 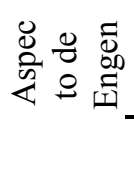 } & $\begin{array}{l}\text { Aspecto de } \\
\text { Engenharia }\end{array}$ & qualitativo & Alto & médio & médio & $\begin{array}{l}\text { médio a } \\
\text { alto }\end{array}$ & alto melhor \\
\hline & $\begin{array}{c}\text { Valor Presente } \\
\text { Líquido }\end{array}$ & qualitativo & baixo & alto & médio & $\begin{array}{l}\text { baixo a } \\
\text { alto }\end{array}$ & alto melhor \\
\hline 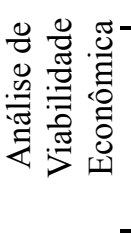 & $\begin{array}{c}\text { Qualificação e } \\
\text { Quantificação } \\
\text { dos Custos } \\
\text { Fixos e } \\
\text { Variáveis } \\
\end{array}$ & $\mathrm{R} \$ /$ ton. & 20 & 18 & 19 & 18 a 20 & menor valor \\
\hline \multirow{4}{*}{ 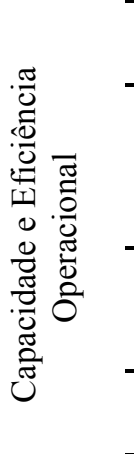 } & $\begin{array}{c}\text { Capacidade } \\
\text { Estática }\end{array}$ & kton. & 30 & 100 & 50 & $\begin{array}{l}30 \mathrm{a} \\
100\end{array}$ & maior valor \\
\hline & $\begin{array}{c}\text { Eficiência dos } \\
\text { sistemas e } \\
\text { linhas de } \\
\text { processamento }\end{array}$ & qualitativo & baixo & alto & médio & $\begin{array}{l}\text { baixo a } \\
\text { alto }\end{array}$ & alto melhor \\
\hline & $\begin{array}{l}\text { Utilização } \\
\text { (Giros de } \\
\text { Armazém) } \\
\end{array}$ & giros & 3 & 1 & 2 & 1 á 3 & maior valor \\
\hline & $\begin{array}{l}\text { Qualidade do } \\
\text { Produto }\end{array}$ & qualitativo & Alto & baixo & médio & $\begin{array}{l}\text { baixo a } \\
\text { alto }\end{array}$ & alto melhor \\
\hline
\end{tabular}

\section{Quadro 20- Valoração dos atributos}

O quadro 20 mostra as alternativas de projetos hipotéticos criadas sendo suas principais características:

- Projeto A é composto de um silo metálico com plenamente dos requisitos (obrigatório e recomendado) atendidos segundo a Instrução Normativa $\mathrm{N}^{\circ} 29$ e capacidade de 30.000 
toneladas. Quanto à localidade, fica situado numa área rural próxima às fazendas e com grande potencial de aumento participação do mercado (Market Share). Como a capacidade do armazém é relativamente baixa, necessitará de muitos giros de armazém para garantir diminuição de custos e VPL maior que zero, desta maneira sua atratividade econômica é baixa;

- Projeto B é composto de um armazém graneleiro com plenamente dos requisitos obrigatórios atendidos segundo a Instrução Normativa N²9 e capacidade de 100.000 toneladas. Quanto à localidade, fica situado numa área rural mais afastado das fazendas com médio potencial de aumento de participação do mercado (Market Share), já que o mesmo já se encontra mais consolidado. Devido a sua elevada capacidade do armazém sua atratividade econômica é alta, uma vez que consegue diluir melhor seus custos fixos;

- Projeto C é composto de um armazém graneleiro com plenamente dos requisitos obrigatórios atendidos segundo a Instrução Normativa No29 e capacidade de 50.000 toneladas. Quanto à localidade, fica situado numa área urbana com baixo potencial de aumento na participação do mercado (Market Share). Devido a sua média capacidade do armazém sua atratividade econômica é média, já que dependerá de giros de armazém para garantir o volume necessário para balancear seus custos.

\subsection{Etapa 3 - Aplicar o modelo a um exemplo - uso do software V.I.S.A.}

Esta etapa será analisada por meio da aplicação do modelo de decisão multicritério proposto e análise de sensibilidade, utilizando do software V.I.S.A. com o objetivo de indicar dentre os três projetos hipotéticos mencionados anteriormente qual o projeto que agregará maior valor à trading e o comportamento de cada projeto em relação à valoração dos critérios.

Após a determinação dos pesos dos critérios e atributos, das escalas de valores de cada atributo e dos valores das alternativas, como apresentados anteriormente, estas informações foram inseridas no software V.I.S.A. para sua modelagem matemática. Os resultados podem ser vistos na Figura 27. 


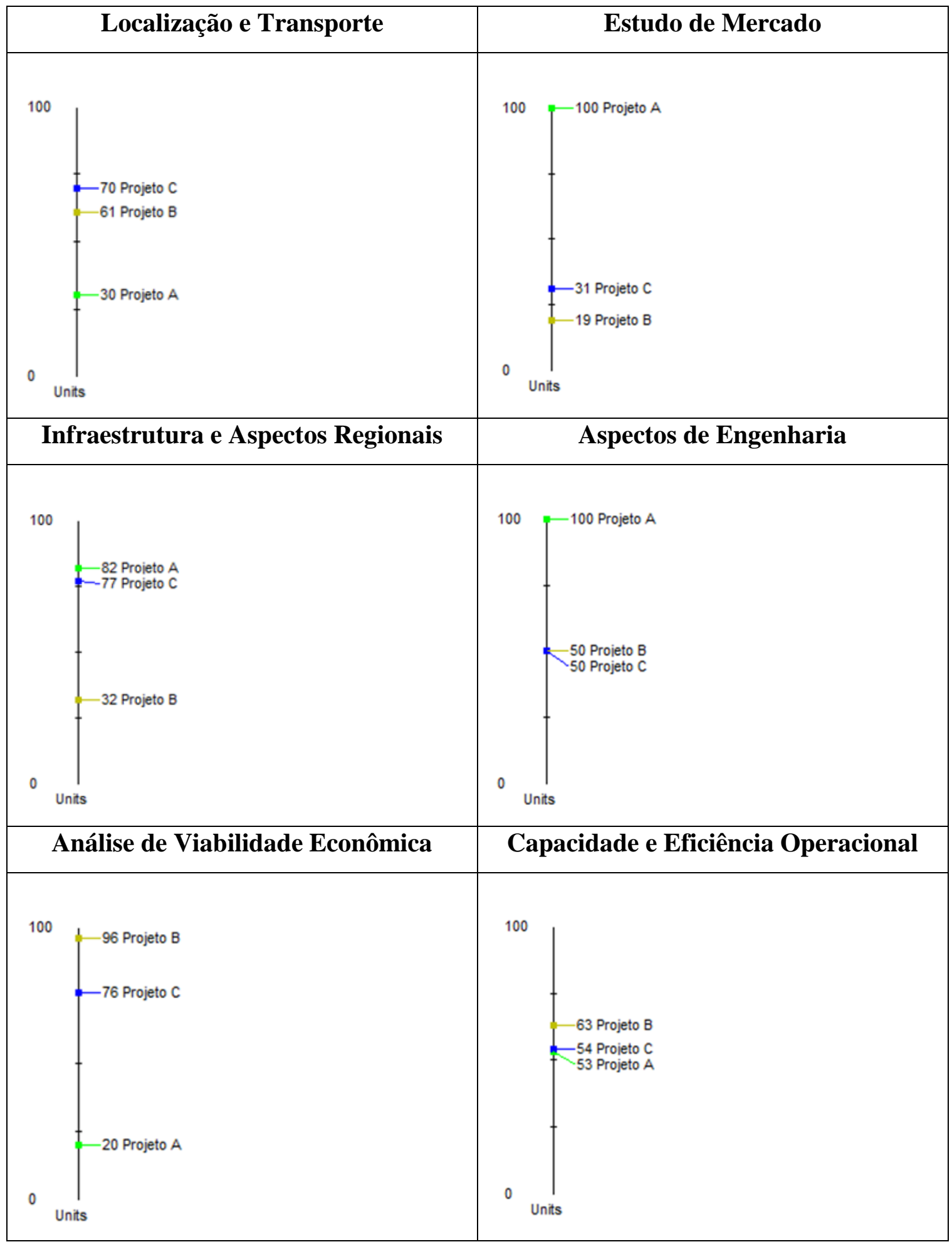

Figura 27 - Resultados dos projetos por critério obtidos a partir da modelagem no software V.I.S.A.

Como mostra a Figura 27, o projeto A obteve maior pontuação local nos critérios "Estudo de Mercado", "Infraestrutura e Aspectos Regionais" e "Aspectos de Engenharia”, o que significa que o Projeto A melhor atende as exigências destes três objetivos quando comparado com os outros três projetos. Isto se deve, principalmente, à região onde o projeto será instalado 
apresentar o maior potencial de crescimento de produção de soja e de demanda pelos serviços de armazenagem, características essenciais de mercado. Em contrapartida, nos critérios "Localização e Transporte", “Análise de Viabilidade Econômica" e "Capacidade e Eficiência Operacional", o projeto A apresentou as menores pontuações, o que significa que os outros dois projetos atendem melhor às expectativas dos decisores sob estes três aspectos.

O projeto B apresentou maiores pontuações nos critérios "Análise de Viabilidade Econômica" e "Capacidade e Eficiência Operacional", fato este alavancado pela maior capacidade estática do armazém (100 kt) dentre os três projetos, o que pode ser considerado o ponto forte deste projeto. Porém a região onde o projeto será inserido não atende plenamente as necessidades dos decisores quanto às demandas do "Estudo de Mercado" e exigências de "Infraestrutura e Aspectos Regionais", nos quais obtiveram menores pontuações.

E, por fim, o projeto C foi melhor pontuado quanto a sua "Localização e Transporte". Apesar de ser o projeto mais distante das principais áreas produtoras, a região apresenta melhor sistema de transporte e maior disponibilidade de frota com fretes mais baratos dentre os outros projetos. Em relação ao critério "Aspectos de Engenharia", apesar de atender aos requisitos mínimos da Instrução Normativa 29 para obter a certificação da unidade armazenadora, os outros dois projetos apresentam mais requisitos não obrigatórios atendidos, o que ocasionou na menor pontuação do projeto $C$, neste quesito. Nota-se também que o projeto $\mathrm{C}$ ficou em segundo lugar nos outros quatro critérios.

Como se trata de uma decisão multicritério, o resultado final é a seleção do projeto que obtém a maior pontuação geral do somatório dos valores de cada projeto (alternativa) ponderados pelos pesos de cada critério. Ou seja, o modelo elege o projeto que melhor atender a maioria dos objetivos exigidos na decisão. Sendo assim, o modelo de decisão de investimento de soja em grão proposto por este trabalho, sob a visão do grupo, foi o projeto $\mathrm{C}$, como mostra a Figura 28. 


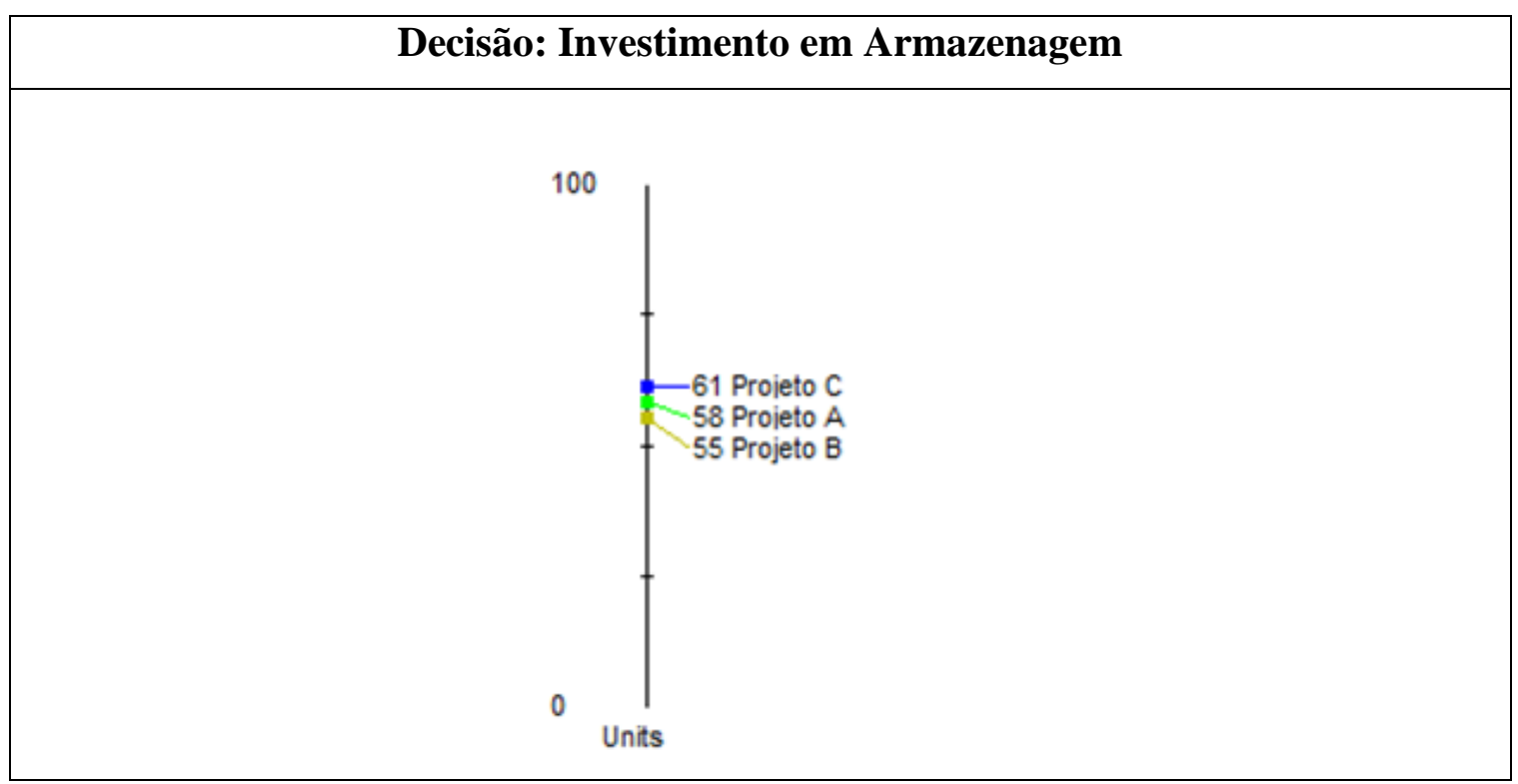

Figura 28 - Resultado da decisão de investimento proposto pelo modelo construído

Ao considerar o modelo proposto, conclui-se que o investimento que trará melhor valor à empresa que investir é o projeto $\mathrm{C}$, porém nota-se na Figura 28 que a diferença de valor entre os projetos foi pequena: de 3 pontos para o segundo colocado, projeto A, e 6 pontos em relação ao projeto $\mathrm{B}$.

\subsubsection{Análise de Sensibilidade e Robustez}

Para avaliar a coerência dos critérios e assertividade dos resultados da análise multicritério foram realizadas análises de sensibilidade. Os dois resultados considerados mais relevantes que serão discutidos se tratam de quais alterações aos pesos dos critérios propostos na decisão do grupo seriam necessárias para que o modelo passasse a sugerir a seleção do A e, depois, do projeto B.

De acordo com o perfil do projeto A, as condições que fariam com que o modelo indicasse esta alternativa como a mais indicada teria que apresentar o peso do critério "Estudo de Mercado" com valor superior aos valores dos outros 5 critérios, impulsionado pelo aumento do peso dos atributos "concorrência" e "demanda de produto", como pode ser visto na Figura 29. Isto se deve ao fato de que o valor no atributo "concorrência" e "demanda de produto" do projeto A são superiores aos valores do projeto B e C. Isso daria vantagem ao projeto A em 
relação aos projetos B e C, por permitir o maior potencial de aumento Market Share da empresa na região deste projeto.

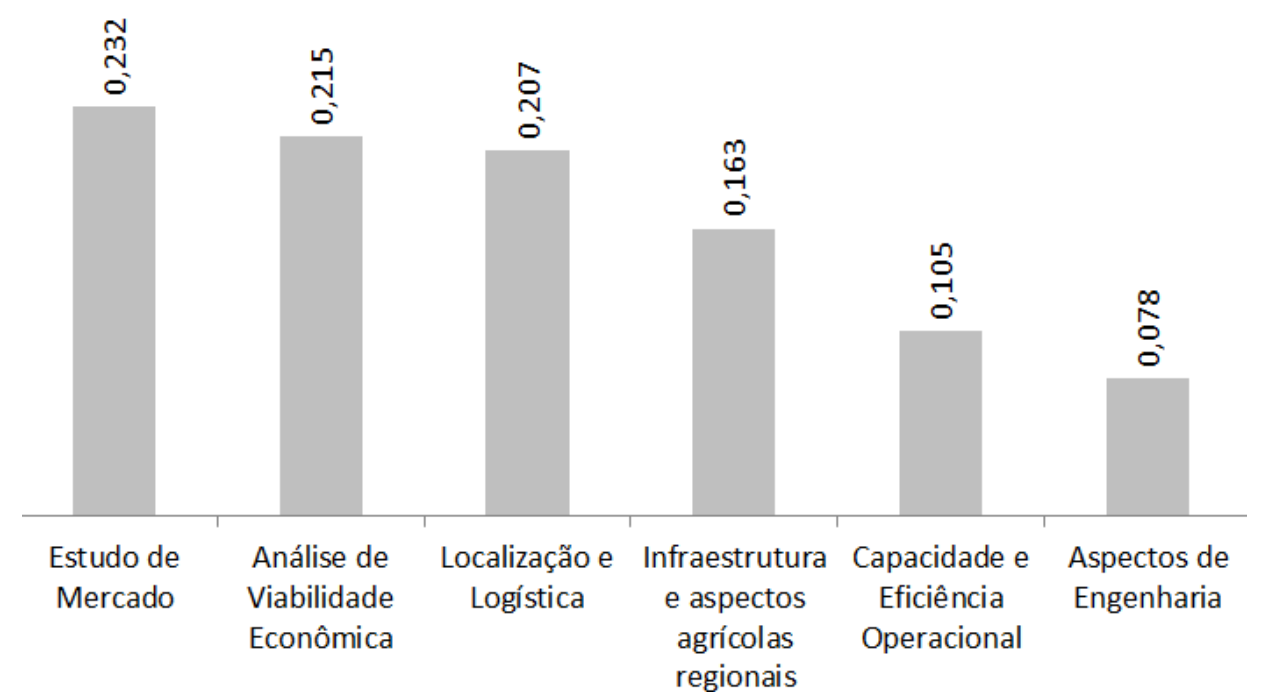

Figura 29 - Resultado da análise de sensibilidade no software V.I.S.A. com as condições necessárias para que o modelo selecione o projeto A como melhor alternativa

Agora de acordo com o perfil do projeto $\mathrm{B}$, as condições que fariam com que o modelo indicasse esta alternativa como a mais indicada teria que apresentar o peso do critério "Capacidade Eficiência Operacional" com valor superior aos valores dos outros 5 critérios, impulsionado pelo aumento do peso dos atributos "capacidade estática" e "eficiência dos sistemas operacionais", como mostra a Figura 30. Isto se deve ao fato de que os valores do projeto B nestes atributos são superiores aos valores do projeto A e C. Isso daria vantagem ao projeto B em relação aos projetos A e C por permitir o maior potencial em garantir o alcance do objetivo do armazenamento que é guardar e preservar as características que os grãos apresentam após a colheita, diminuindo ao máximo as perdas, utilizando-se, da melhor maneira possível, a capacidade e as técnicas existentes. 


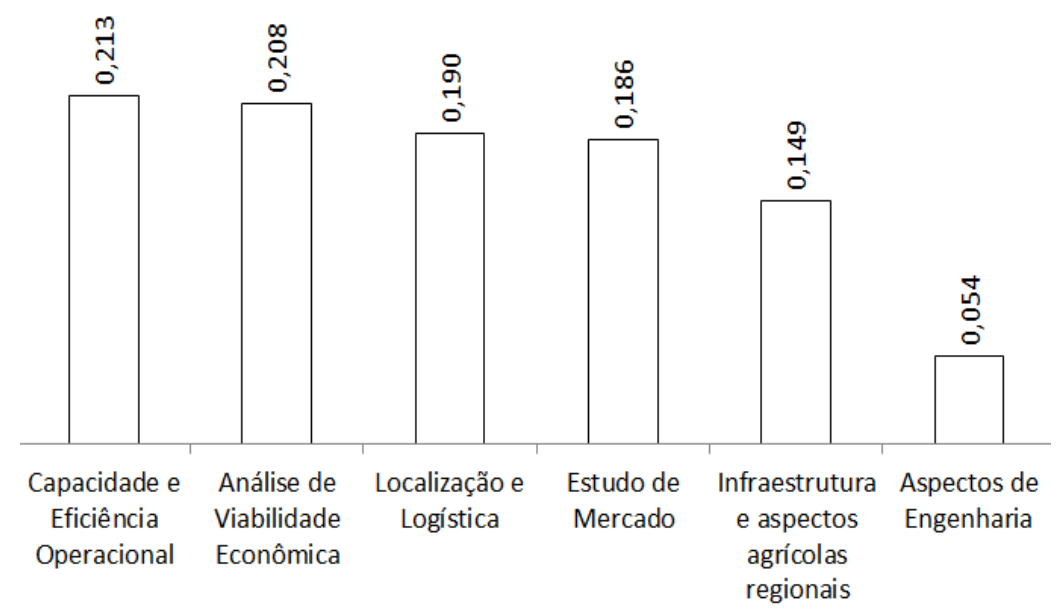

Figura 30 - Resultado da análise de sensibilidade no software V.I.S.A. com as condições necessárias para que o modelo selecione o projeto B como melhor alternativa

Comparando os resultados da decisão do grupo com os resultados da análise de sensibilidade como mostra a Figura 31, observa-se que os critérios mais sensíveis são os que apresentam o menor desvio entre os resultados das análises de sensibilidade e a decisão do modelo proposto. São eles: "Infraestrutura e Aspectos agrícolas da região" e "Análise de viabilidade econômica". Enquanto o critério "capacidade e eficiência operacional" é o menos sensível à mudança (com maior desvio), o que confere robustez ao modelo. Ou seja, a conservação da qualidade e controle de perdas parecem ser características fundamentais na escolha de projetos em armazenagem, seja pelo ponto de vista do eficiente controle de estoque e adequada capacidade estática de armazenagem, seja pela eficiência dos sistemas e linhas de processamento e qualidade do grão.

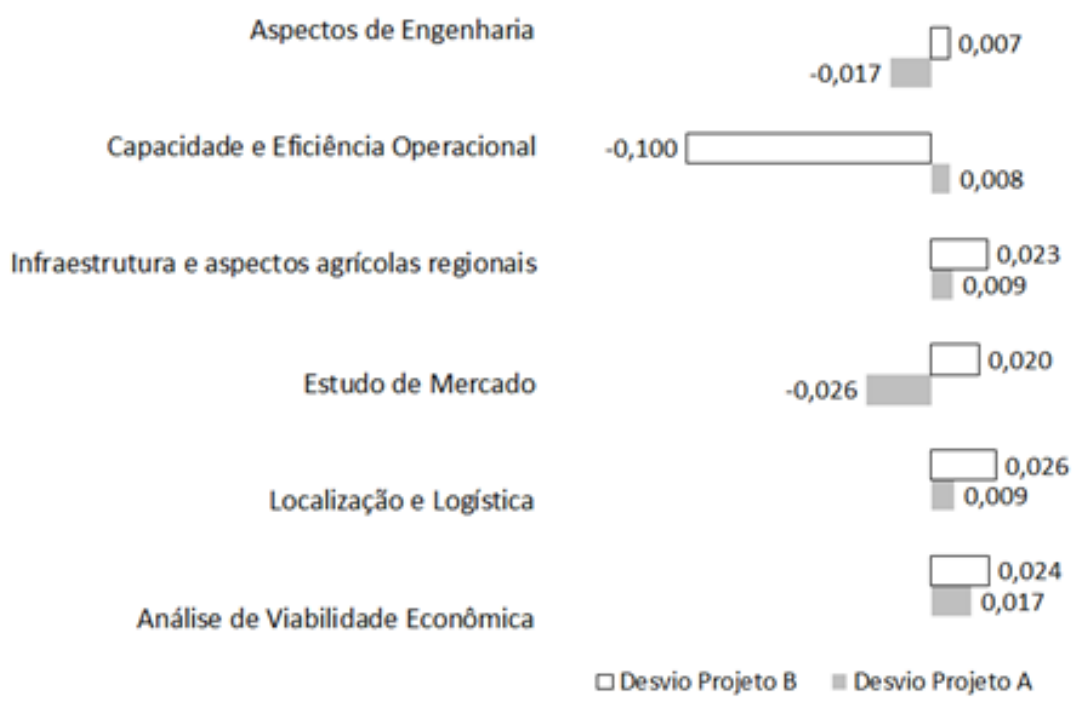

Figura 31 - Análise de sensibilidade dos critérios quanto à mudança nos pesos 
$\mathrm{Na}$ análise de projetos reais, o critério "Localização e Logística de transporte", embora apresente pouca sensibilidade a mudanças apresentadas nos projetos hipotéticos, certamente o aumento ou diminuição do seu peso poderá influenciar substancialmente na escolha do projeto de investimento, uma vez que a localização entre o armazém e os pontos de origem (fazenda) e destino (mercado consumidor), o preço de frete e a frota disponível na região poderão alterar a necessidade de aumentar ou diminuir a capacidade estática e aumentar o giro do armazém. Analogamente, dependendo da região, "Infraestrutura e aspectos agrícolas regionais" também poderão influenciar na escolha do armazém, pois fluxos frequentes de carga, períodos de safra e entressafra, além de custos locais de armazenagem serão relevantes à medida que revela as necessidades de atendimento de diversas demandas (sociais, ambientais e espaço físico para armazenagem). 


\section{CONCLUSÕES}

A principal contribuição desta pesquisa foi construir um modelo de decisão multicritério de armazenagem de soja em grão com base na literatura e no pensamento de valor de profissionais que trabalham no setor. Sendo assim, um modelo genérico para uso em decisão por uma empresa deste ramo foi construído e um exemplo hipotético foi criado para sua validação.

A pesquisa revelou quais são os critérios de maior relevância, além da análise econômica, para a escolha de projetos de investimento em centros de armazenagem, segundo as preferências de um grupo de decisores. Certamente, os critérios "Localização e Logística de Transporte", "Infraestrutura e Aspectos agrícolas regionais" e "Capacidade e Eficiência operacional", embora sejam independentes entre si sob o ponto de vista da modelagem das preferências do grupo, referem-se exclusivamente aos aspectos logísticos. Logo, a análise conjunta desses critérios demandam mais pesquisas, pois parecem ter destaque na decisão de investimento em armazenagem e, como exposto, são o gargalo frente ao cenário futuro de aumento da safra e de consumo

O publico alvo desta dissertação são gerentes e diretores que sejam tomadores de decisão em investimento de projetos de unidade armazenadora do agronegócio. A utilização deste trabalho por este público pode ser utilizada como referência para compor a sua árvore de decisão e as preferências obtidas podem auxiliar processos de tomadas de decisão reais. Outra relevante contribuição deste trabalho é a agregação de opiniões individuais para se obter uma valoração quantitativa da decisão de um grupo. Fato este que aproxima da realidade os processos de tomada de decisão em empresas, pois, geralmente, mais de uma pessoa e diversas áreas estão envolvidas numa decisão de investimento em projeto de armazenagem.

Apesar de ser uma aplicação de um exemplo e não de um estudo de caso real, o modelo proposto demonstrou-se coerente em relação ao perfil das alternativas hipotéticas criadas e validada pela análise de sensibilidade e robustez.

A principal limitação deste trabalho se encontra na coleta de dados em relação à escala de valor de alternativas. Nesta pesquisa, esta escala foi definida unicamente pelo analista do processo de tomada de decisão. A ampliação da coleta de dados pelos decisores desta escala de valor poderá ser considerada em trabalhos futuros. 
Outro fator que pode ser considerado como limitação deste trabalho é a utilização de um software especializado em decisão multicritério para a construção da modelagem matemática e análise de sensibilidade do modelo. Como se trata de um software comercial, requer investimento para sua aquisição, o que talvez possa ser um fator impeditivo para investimento. Como alternativa, a modelagem matemática pode ser feita no software MS Excel, pertencente ao pacote MS Office, que é o mais utilizado pelas empresas. A limitação desta substituição é a perda da interface dinâmica da análise de sensibilidade disponível no V.I.S.A., o que pode ser tabulado e analisado estaticamente numa planilha.

Outra recomendação para compor futuras pesquisas sobre o assunto encontra-se na inclusão de uma análise de incerteza, a partir da construção de uma árvore de probabilidade para as alternativas propostas no modelo, baseadas na previsão de realização da produtividade da safra e dados históricos para a definição das condições de sucesso e fracasso; de análise de cenários e/ou da elaboração de mais critérios que levem alguma análise de incerteza em sua construção para minimizar o risco da decisão. 


\section{REFERÊNCIAS BIBLIOGRÁFICAS}

ABBAS, T. E.; MAHDI, H. MCDM methodologies and applications: literature review from 1999 to 2009. Research Journal of International Studies, v.21, pág. 86-137.

ABIOVE, Associação Brasileira das Indústrias de Óleos Vegetais. Complexo de Soja: Balanço de Oferta/Demanda. Disponível em 〈http://www.abiove.com.br/balanco_br.html $>$ Acesso em: 6 de janeiro de 2011.

ACZEL. J. \& ROBERTS, F.S. On the Possible Merging Functions. Mathematical Social Sciences, 1989.

ACZEL, J.; SAATY, T.L. Procedures for Synthesizing Ratio Judgments. Journal of Mathematical Psychology, 1983.

AFOnSO, H. C. A. G. Análise dos custos de transporte da Soja Brasileira, 2006. Dissertação (Mestrado) - Engenharia de Transportes, Instituto Militar de Engenharia, Rio de Janeiro, RJ.

AGRELL, P. J.; STAM, A.; FISHER, G. W. 2004. Interactive multiobjective agro-ecological land use planning: The Bungoma Region in Kenya. European Journal of Operational Research, v. 158, 194-217, 2004

ANANDA, J; HERATH, G. A critical review of multi-criteria decision making methods with special reference to forest management and planning. Ecological Economics, v.68, pág. 2535-2548, 2009.

ANDERSON, V. L. et al Avaliação da capacidade dos terminais de granéis agrícolas utilizados para escoamento da produção do centro-oeste brasileiro. Disponível em: $\langle$ http://www.gestaonaval.org.br/Workshops.aspx?area=Logistica $>$, acesso em 20 de janeiro, 2011.

ANDRE, F. J. Indirect elicitation of non-linear multi-attribute utility functions. A dual procedure combined with DEA. Omega International of Management Science. v.37, n.4, pág. 883-895, 2009. 
ANDRE, F. J.; RIESGO, L. A non-interactive elicitation method for non-linear multiattribute utility functions: Theory and application to agricultural economics. European Journal of Operational Reaserch. v.181, n.2, pág. 793-807, 2007.

ANGILELLA, S. et al. Assessing non-additive utility for multicriteria decision aid. European Journal of Operational Reaserch. v.158, n.3, pág. 734-744, 2004.

AZEVEDO, L. F; OLIVEIRA, T. P; PORTO, A. G; SILVA, F. S. A capacidade estática de armazenamento de grãos no Brasil. XXVIII Encontro Nacional de Engenharia de Produção, 2008 .

BALlOU, R. H. Gerenciamento da Cadeia de Suprimentos/ Logística Empresarial. 5.ed. Porto Alegre: Bookman, 2006.

BARFORD, M. B. An MCDA approach for the selection of bike projects bases on structuring and appraising activities. European Journal of Operational Reaserch. v. 218, pág. 810-818, 2011.

BELTON, V.; STEWART, T. J. Multiple Criteria Decision Analysis: an integrated approach. 2.ed., Boston: Kluwer Academic Publishers, 2002.

BIAGI, J.D. et al. Secagem de produtos agrícolas: Introdução à Engenharia Agrícola. Editora Unicamp: Campinas, p. 245-266. 1993.

BIAGI, J. D.; BERTOL, R.; CARNEIRO, M. C. Armazéns em Unidades centrais de Armazenamento (Cap. 3) In: LORINI, I.; MIIKE, L. H. \& SCUSSEL, V. M.; Armazenagem de Grãos. Instituto Bio Geneziz: Campinas, 2002.

BOSE, U.; PARADICE, D. B. The effects of integrating cognitive feedback and multiattribute utility-based multicriteria decision-making methods in GDSS. Group Decision Negotiation. v. 8, n.2 pág.157-182, 1999.

BOSE, U.; DAVEY, A. M.; OLSON, D. L. Multi-attribute Utility Methods in Group Decision Making: Past Applications and Potencial for Inclusion in GDSS. Omega International Journal of Management Science. v. 25, n.6, pág. 691-706, 1997. 
BRAGATTO, S. A.; BARRELA, W. D. Otimização do Sistema de Armazenagem de Grãos: Um estudo de caso. Revista Produção Online. v.1, n.1, 2001.

BRITO, A. J.; ALMEIDA, A. T; MOTA, C. M. M. A multicriteria model for risk sorting of natural gas pipelines based on ELECTRE TRI integrating Utility Theory. European Journal of Operational Reaserch. v.200, n.3, pág. 812-821, 2010.

BROOKER, D. B.; BAKKER-ARKEMA, F.W.; HALL, C.W. Drying and storage of grains and oilseeds. New York: Van Nostrand Reinhold, 1992.

BUAINAIM, A. M.; VIEIRA, A. C. P.; VIEIRA JUNIOR, P. A. Análise da governança da cadeia da soja. VIII Congresso Latino-americano de Sociologia Rural, 2006.

CAIXETA-FILHO, J. V.; MARTINS, R. S. Gestão Logística do transporte de Cargas. São Paulo: Atlas, 2001.

CALKER, K. J. V. et al. Development and application of a multi-attribute sustainability function for Dutch dairy farming systems. Ecological Economics, v.57, 640-658, 2006.

CAMBOLAT, Y. B.; CHELST, K; GARG, N. Combining decision tree and MAUT for selection a country for a global manufacturing facility. Omega International Journal of Management Science, v. 35, pág. 312-325, 2005.

CARBINATTO, G. Opções Reais no Complexo Soja: Aplicações na Valoração de Opções de Investimentos Produtivos. Dissertação (Mestrado) - Escola de Administração de Empresas, Faculdade Getúlio Vargas, São Paulo, SP. 2003

CEPEA, Centro de Estudos Avançados em Economia Aplicada. PIB do Agronegócio-Dados de 2004 a 2011. Disponível em $<$ http://www.cepea.esalq.usp.br/ $>$ Acesso em: 17 de julho de 2012.

CHOU, C. C. Integrated short-term and long-term MCDM model for solving location selection problem. Journal of Transportation Engineering, v.1 35, n.11, pág. 880-893, 2009. 
COOK, D.; PROCTOR, W. Assessing the threat of exotic plant pests. Ecological Economics, v.63, 594-604, 2007.

CORREA JÚNIOR, G. Principais determinantes de preço do frete rodoviário para o transporte de soja em grãos em diferentes estados brasileiros: uma análise econométrica. Dissertação (Mestrado) - Escola Superior de Agricultura Luiz de Queiroz, Piracicaba, 2001.

CRUZ, M. H. Utilização de uma metodologia de apoio a decisão na análise de outsourcing em uma empresa de metalurgia. Dissertação (Mestrado) - Faculdade de Engenharia Mecânica, Universidade Estadual de Campinas, Campinas, SP, 2011.

DALBELLO, O. Eficiência do processo de secagem do amendoim (Arachis hypogea L.) e milho-pipoca (Zea mays L.). Dissertação (Mestrado) - Faculdade de Engenharia Agrícola Campinas, Campinas, SP. 1995.

D’ARCE, M. A. B. R. Pós colheita e Armazenamento de Grãos. Disponível em: s http://www.esalq.usp.br/departamentos/lan/pdf/Armazenamentodegraos.pdf >. Acesso em: 11 de junho, 2012.

DEMIREL, T.; DEMIREL, N. Ç.; KAHRAMAN, C. Multi-criteria warehouse location selection using Choquet integral. Expert System with Applications, v. 37, pág. 3943-3953, 2010 .

DEVILLA, I. A. Projeto de Unidades Armazenadoras, 2004. Disponível em: < http://www.ebah.com.br>. Acesso em: 10 de junho, 2012.

DURBACH, I. N.; STEWART, T. J. A comparison of simplified value function approaches for treating uncertainty in multi-criteria decision analysis. Omega International Journal of Management Science, v. 40, pág. 456-468, 2012.

FAPRI. Food and Agricultural Policy Research Institue. World agricultural outlook 2008. Disponível em: < http://www.fapri.iastate.edu/publications $>$. Acesso em: em 15 de julho de 2012. 
FAPRI. Food and Agricultural Policy Research Institue. World agricultural outlook 2010. Disponível em: < http://www.fapri.iastate.edu/publications $>$. Acesso em: em 15 de julho de 2012.

FORMAN, E., PENIWATI, K. Aggregating individual judgements and priorities with the Analytic Hierarchy Process , European Journal of Operational Research. Vol. 108, pp. 165-169, 1998.

FREDERICO, S. Desvendando o agronegócio: financiamento agrícola e o papel estratégico do sistema de armazenamento do sistema de grãos. GEOUSP - Espaço e Tempo, São Paulo, $\mathrm{N}^{\mathrm{o}} 27$, p. $47-61,2010$.

GALLARDO, A. P. et al. Avaliação da Capacidade de Infra-estrutura de Armazenagem para os Granéis Agrícolas Produzidos no Centro-Oeste Brasileiro, 2010. Disponível em: <http://www.ipen.br>. Acesso em: 29 de dezembro, 2010.

GAMEIRO, A. H. Índices de preços para o transporte de cargas: o caso da soja a granel. Tese (Doutorado) - Escola Superior de Agricultura Luiz de Queiroz, Piracicaba, SP, 2003.

GOMES, L. F. A. M.; GOMES, C. F. S.; ALMEIDA, A. T. Tomada de Decisão Gerencial: enfoque multicritério. 2.ed. São Paulo: Atlas, 2002.

GOMES-LIMON, J. A.; ARRIAZA, M.; RIESGO, L. An MCDM analysis of agricultural risk aversion. European Journal of Operational Reaserch. v. 151, n.3, pág. 569-585, 2003.

GOODWIN, P., WRIGHT, G. Decision Analysis for Management Judgment. 3.ed., Chichester: John Wiley \& Sons, 2004.

HAJKOWICZ, S. A.; McDONALD, G. T.; SMITH, P. N. R. An evaluation of multiple objective decision support weighting techniques in natural resource management. Journal of Enviromental Planning and Management. v. 43, pág. 505-518, 2000.

HENDERSON, S. M., PERRY, R. L. Agricultural Process Engineering. Westport, Connecticut - EUA: The Avi Publishing Company, 1976. 
HAYES, R.; GARVIN, D. Managing as if Tommorow Mattered. Harvard Business Review, p. 71-79, Mai.-Jun. 1982.

IBGE, Instituto Brasileiro de Geografia e Estatística. Sistema IBGE de Recuperação Automática: Produção Agrícola e Estoques. Disponível em: < http://www.ibge.gov.br/home/>. Acesso em: 17 de julho de 2012.

JIMENEZ, A.; MATEOS, A.; RIOS-INSUA, S. Missing consequences in multiattribute utility theory. Omega International Journal of Management Science. v. 37, n.2, pág. 395410, 2009.

KAZANA, V.; FAWCETT, R. H.; MUTCH, W. E. S. A decision support modeling framework for multiple use forest management: The Queen Elizabeth Forest case study in Scotland. European Journal of Operational Research, v.148, 102-115, 2003.

KEENEY, R. L. Value-focused thinking: Identifying decision opportunities and creating alternatives. European Journal of Operational Reaserch. v. 92, pág. 537-549, 1996.

Value-focused thinking: A Path to Creative Decision Analysis. Harvard University Press, Cambridge, 1992.

KEENEY, R. L.; GREGORY, R. I. Selecting Attributes to Measure the Achievement of Objetives. Operational Reaserch. v.53, n.1, pág. 1-11, janeiro-fevereiro, 2005.

KNOB, A. H. Aplicação do processamento de imagens digitais para análise da anisotropia da massa de grãos. Dissertação (Mestrado) - Universidade Regional do Noroeste do Estado do Rio Grande do Sul, Ijuí, RS, 2010

KORPELA, J.; LEHMUSVAARA, A.; NISONEN, J. Warehouse operator selection by combining AHP and DEA methodologies. International Journal of Production Economics. v. 108, pág. 135-142, 2007.

LACERDA FILHO, A. F.; SILVA, Juarez de Souza; RESENDE, R. C. Estruturas para armazenagem de grãos. In: Juarez de Souza e Silva. (Org.). Secagem e armazenagem de produtos agrícolas. 1ed.,Viçosa: Editora Aprenda Fácil, 2000, v. 1, p. 325-344. 
LÓPEZ, C. P.; REQUENA, J. C.; GIMÉNEZ, T. D. H. A systemic comparative assessment of the multifunctional performance of alternative olive systems in Spain within an AHPextended framework. Ecological Economics. V.64, 820-834, 2008.

MAPA, Ministério da Agricultura, Pecuária e Abastecimento. Projeções do Agronegócio. 2009. Disponível em: < http://www.agricultura.gov.br/>. Acesso em: 28 de dezembro de 2010.

Projeções do Agronegócio. 2010/2011 a 2020/2021. Disponível em: < http://www.agricultura.gov.br/>. Acesso em: 18 de julho de 2012.

MARTINS, R. S. et al. Decisões estratégicas na logística do agronegócio: compensação de custos transporte-armazenagem para a soja no estado do Paraná. Revista de Economia e Sociologia Rural [online], vol.9, n.1, pp. 53-78, 2005.

MARTINS, R. S. Estudo da formação do frete rodoviário e potencial de conflitos em negociações em cadeias do agronegócio brasileiro. Organizações Rurais \& Agroindustriais, vol.10, n.1, p. 73-87, 2008.

MDIC, Ministério do Desenvolvimento, Indústria e Comércio Exterior. Balança Comercial Brasileira: Dados Consolidados, 2009. Disponível em< http://www.desenvolvimento.gov.br/arquivos/dwnl_1275505327.pdf $>$ Acesso em: 28 de dezembro de 2010.

Balança Comercial Brasileira: Dados Consolidados, 2011. Disponível em< http://www.desenvolvimento.gov.br/> Acesso em: 15 de julho de 2012.

MINISTÉRIO DOS TRANSPORTES. Plano Nacional de Logística e Transportes. Relatório $\quad$ Executivo, 2007. Disponível em 〈http://www.transportes.gov.br/index/conteudo/id/3280 $>$. Acesso em: 30 de dezembro de 2010.

MORAIS, D. C.; ALMEIDA, A. T. Group decision making on water resources based on analysis of individual rankings. Omega International Journal of Management Science. v. 40, pág. 42-52, 2012. 
MYERS, S. C. Determinant of Corporate Borrowing. Journal of Financial Economics. V.5, p. 147-175, 1977.

NOGUEIRA, M. C. et al. Priorização de investimentos para o desenvolvimento logístico do Mato Grosso voltado para o escoamento da produção agrícola. XXII Congresso Nacional de Transporte Aquaviário, Construção Naval e Offshore, 2008.

NOGUEIRA, M. C. et al. Impacto da Logística na Competitividade Agrícola do Mato Grosso. XXII Congresso Nacional de Transporte Aquaviário, Construção Naval e Offshore, 2008.

NOGUEIRA JUNIOR, S.; TSUNECHIRO, A. Produção Agrícola e Infra-estrutura de Armazenagem no Brasil. Revista Informações Econômicas, São Paulo, v.35, n.2, fev, 2005.

OJIMA, A. L. R. O.; ROCHA, M. B. Desempenho logístico e inserção econômica do agronegócio da soja: as transformações no escoamento da safra. XLIII Congresso Sociedade Brasileira de Economia e Sociologia Rural, Ribeirão Preto, 2005.

OJIMA, A. L. R. O.; YAMAKAMI, A. Modelo de programação quadrática para análise da movimentação logística e comercialização da soja brasileira. Engenharia Agrícola Jaboticabal, v. 26, n. 2, p. 552-560, 2006.

OLIVEIRA, A. M. K.; CAIXETA FILHO, J. V. Potencial da logística ferroviária para exportação de açúcar em São Paulo: recomendações de localização para armazéns intermodais. Revista de Economia e Sociologia Rural [online]. vol. 45, n.4, 2007.

OLIVEIRA, W.; ALINE, R. P.; BORSATTO, R. S.; WEBER, E. F. Capacidade dinâmica de armazenagem de grãos a granel na mesorregião de Itapetininga-SP. Revista Científica da Faculdade de Tecnologia de Tatuí, v.2, n.1, 2009.

ÖZCAN, T.; ÇELEBI, N; ESNAF, S. Comparative analysis os multi-criteria decision making methodologies and implementation of a warehouse location selection problem. Expert System with Applications, v. 38, pág. 9773-9779, 2011.

PARDALOS, P. M.; SISKOS, Y.; ZOPOUNIDIS, C. Advances in Multicriteria Analysis. Dordrecht: Kluwer Academic Publishers, 1995. 
PINAZZA, L. A. Cadeia Produtiva da Soja: Volume 2, 2007. Disponível em: < http://www.agricultura.gov.br/>. Acesso em: 28 de dezembro de 2010.

PRADO, A. A. A. Análise de decisão multicritério aplicada na seleção de fornecedores de logística. Dissertação (Mestrado) - Faculdade de Engenharia de Sistemas Logísticos, Universidade de São Paulo, São Paulo, SP. 2011.

ROY, B. ; BOUYSSOU, D. Aide Multicritère à la Décision: Méthodes et Cas. Economica, Paris, 1993.

SAATY, T. L. The Analytic Hierarchy Process, New York: McGraw Hill. International, 1980.

SAHNOUN, H. et al.. GIS and multi-criteria analysis to select potential sites of agroindustrial complex. Environment Earth Science, 2011.

SARKER, R. A.; QUADDUS, M. A. Modeling a nationwide crop planning problem using a multiple criteria decision making tool. Computers \& Industrial Engineering, 42, 541-553, 2002.

SELL, J.; KOELLNER, T.; WEBER, O.; PEDRONI, L.; SCHOLZ, R. W. Decision criteria of European and Latin American market actors for tropical forestry projects providing environmental services. Ecological Economics, 58, 11-36, 2006.

SHIMIZU, T. Decisões nas Organizações. 2.ed., São Paulo: Atlas, 2006.

SILVA, L. C. Estrutura de armazenagem a granel, 2010. Disponível em: <http://www.agais.com>. Acesso em: 01 de maio, 2012.

SIMPSON, L. Do decision makers know what they prefer? MAVT and ELECTRE II Journal of The Operational Society. v. 47, n. 7, pág.919-929, 1996.

SOUZA FILHO, H. M.; GUANZIROLI, C. E.; BUAINAIN, A. M. Metodologia para estudos das relações de mercado em sistemas agroindustriais. 2008. Disponível em: < http://www.iica.org.br/Docs/Publicacoes/Agronegocio/Metodologia_de_Sistemas_Agroindust riais.pdf />. Acesso em: 12 de fevereiro de 2012. 
STEWART, T. J. Use of piecewise linear value-functions in interactive multicriteria decision support - a Monte Carlo study. Journal of The Operational Society. v. 47, n. 5, pág.654$665,1996$.

STRASSERT, G.; PRATO, T. Selecting farming systems using a new multiple criteria decision model: the balancing and ranking method. Ecological Economics, 40, 269-277, 2002.

TRIGEORGIS, L. Real Option and Interactions with Financial Flexibility, Financial Management, p. 202-224, 1993.

VAINIKAINEN, N.; KANGAS, A.; KANGAS, J. Empirical study on voting power in participatory forest planning. Journal of Environmental Management, 88, 173-180, 2008.

WU, W. H.; CHIANG, C. T.; LIN, C. T. Comparing the aggregation methods in the analytic hierarchy process when uniform distribution. Business and Economics, 2008.

YANG, J.; LEE, H. An AHP decision model for facility location selection, Facilities, Vol. 15, pp.241 - 254, 1997

ZANCHET, A. Depósitos Mercantis: um estudo de práticas contábeis dos depositários na comercialização de produtos agrícolas no estado do Paraná. Dissertação (Mestrado) Faculdade de Economia e Administração, Universidade de São Paulo, São Paulo, SP, 2004.

Zadeh, L. A. Fuzzy sets. Information and Control, 8, 338-353, 1965.

ZOPOUNIDIS, C. Multicriteria decision aid in financial management. European Journal of Operational Reaserch. v.119, pág. 404-415, 1999.

ZOPOUNIDIS, C. DOUMPOS M.; ZANAKIS, S. Stock evaluation using a preference disaggregation methodology. Decision Science. v.130, n.2, pág. 402-413, 1999.

ZUFFO, A. C.; REIS, L. F. R.; SANTOS, R. F.; CHAUDHRY, F. H. Aplicação de Métodos Multicriteriais ao Planejamento de Recursos Hídricos. Revista Brasileira de Recursos Hidrícos, Porto Alegre, v.7, n.1, jan/março, 2010. 


\section{APÊNDICE A - Questionário Individual para seleção e pesos dos critérios}

Quais dos critérios abaixo você acha importante considerar no processo de decisão de uma unidade armazenadora de soja em grãos? Por favor, adicione os critérios que você julgar que estão faltando para refletir a sua decisão.

Qual dos atributos abaixo você acha importante considerar para avaliar o critério correspondente? Por favor, adicione os atributos que você julgar que estão faltando para refletir a sua opinião e classificá-los segundo a escala abaixo.

\begin{tabular}{|l|c|l|}
\hline Absolutamente melhor & 9 & 9 vezes mais importante \\
\hline Criticamente melhor & 8 & 8 vezes mais importante \\
\hline Muito fortemente melhor & 7 & 7 vezes mais importante \\
\hline Fortemente melhor & 6 & 6 vezes mais importante \\
\hline Definitivamente melhor & 5 & 5 vezes mais importante \\
\hline Moderadamente melhor & 4 & 4 vezes mais importante \\
\hline Fracamente melhor & 3 & 3 vezes mais importante \\
\hline Pobremente melhor & 2 & 2 vezes mais importante \\
\hline Igual & 1 & Igual \\
\hline Pobremente pior & $1 / 2$ & 2 vezes menos importante \\
\hline Fracamente pior & $1 / 3$ & 3 vezes menos importante \\
\hline Moderadamente pior & $1 / 4$ & 4 vezes menos importante \\
\hline Definitivamente pior & $1 / 5$ & 5 vezes menos importante \\
\hline Fortemente pior & $1 / 6$ & 6 vezes menos importante \\
\hline Muito fortemente pior & $1 / 7$ & 7 vezes menos importante \\
\hline Criticamente Pior & $1 / 8$ & 8 vezes menos importante \\
\hline Absolutamente Pior & $1 / 9$ & 9 vezes menos importante \\
\hline
\end{tabular}

Figura 32 - Escala para comparar os critérios e atributos do questionário 
Universidade de São Paulo

DADOS GERAIS

Nome:

\begin{tabular}{|l|l|}
\hline Cargo e Área: & Data: \\
\hline AVALIAÇÃo DE CRIÍRIOS EM UM PROCESSO DE DECISÃo DE INVESTIIMENTO EM ARMAZENAGEM DE SOJA EM GRÃo \\
\hline Buscando obter o maior valor no processo de tomada de uma decisão de investimento em Armazenagem de Soja em grão, gostaria de saber quais critérios e qual importância entre eles que você
\end{tabular}

Você deverá atribuir para cada item uma nota de 1/9 à 9 , segundo escala ao lado, onde 1/9 significa que o primeiro critério é nove vezes menos importante ou "Pobreamente Pior" em relação ao segundo critério e 9 significa que o primeiro critério é nove vezes mais importante ou "Absolutamente Melhor" em relação ao segundo critério.

Ao completar este formulário de avaliação, você colabora com a minha pesquisa de mestrado pela Universidade de São Paulo

Para comparar o que você considera importante entre os dois critérios:

\begin{tabular}{|c|c|c|c|c|}
\hline 01. & "Localização e Logística" & em relação & "Estudo de Mercado" & Absolutamente melhor \\
\hline 02. & "Localização e Logistica" & em relação & "Infraestrutura e aspectos regionais" & \\
\hline 03. & "Localização e Logística" & em relação & "Aspectos de Engenharia" & \\
\hline 04. & "Localização e Logistica" & em relação & "Análise de Viabilidade Econômica" & \\
\hline 05 . & "Localização e Logistica" & em relação & "Capacidade e Eficiência Operacional" & \\
\hline 06. & "Estudo de Mercado" & em relação & "Infraestrutura e aspectos regionais" & \\
\hline 07. & "Estudo de Mercado" & em relação & "Aspectos de Engenharia" & \\
\hline 08. & "Estudo de Mercado" & em relação & "Análise de Viabilidade Econômica" & \\
\hline 09. & "Estudo de Mercado" & em relação & "Capacidade e Eficiência Operacional" & \\
\hline 10. & "Infraestrutura e aspectos regionais" & em relação & "Aspectos de Engenharia" & \\
\hline 11. & "Infraestrutura e aspectos regionais" & em relação & "Análise de Viabilidade Econômica" & \\
\hline 12. & "Infraestrutura e aspectos regionais" & em relação & "Capacidade e Eficiência Operacional" & \\
\hline 13. & "Aspectos de Engenharia" & em relação & "Análise de Viabilidade Econômica" & \\
\hline 14. & "Aspectos de Engenharia" & em relação & "Capacidade e Eficiência Operacional" & \\
\hline 15. & "Análise de Viabilidade Econômica" & em relação & "Capacidade e Eficiência Operacional" & \\
\hline 16. & Outro critério que considera relevante: & & & \\
\hline
\end{tabular}

Para comparar o que você considera importante entre os dois atributos em relação ao critério "Localização e Logística":

\begin{tabular}{|llll|l}
\hline 01. & "Localização" & em relação & "Preço de frete da região" & Criticamente melhor \\
\hline 02. & "Localização" & em relação & "Frota disponivel na região" & \\
\hline 03. & "Localização" & em relação & "Modais de recepção e expedição" & \\
\hline 04. & "Preço de frete da região" & em relação & "Frota disponivel na região" & \\
\hline 05. & "Preço de frete da região" & em relação & "Modais de recepção e expedição" & \\
\hline 06. & "Frota disponivel na região" & em relação & "Modais de recepção e expedição" & \\
\hline 07. & Outro atributo que considera relevante para o critério "Localização e Logistica": & \\
\hline
\end{tabular}

Para comparar o que você considera importante entre os dois atributos em relação ao critério "Estudo de Mercado":

\begin{tabular}{|c|c|c|c|c|}
\hline 01. & "Concorrência" & em relação & "Aumento de Produção (Oferta)" & Criticamente melhor \\
\hline 02. & "Concorrência" & em relação & "Demanda de Produto" & \\
\hline 03. & "Demanda de Produto" & em relação & "Aumento de Produção (Oferta)" & \\
\hline
\end{tabular}

04. Outro atributo que considera relevante para o critério "Estudo de Mercado":

Para comparar o que você considera importante entre os dois atributos em relação ao critério "Infraestrutura e Aspectos Regionais":

\begin{tabular}{|clcc|c|}
\hline 01. & "Aspectos agrícolas e Ambientais" & em relação $\quad$ "Demanda de Armazenagem da Região " & Criticamente melhor \\
\hline 02. & "Aspectos agricolas e Ambientais" & em relação $\quad$ "Aspectos Sociais" & \\
\hline 03. & "Aspectos Sociais" & em relação $\quad$ "Demanda de Armazenagem da Região " & \\
\hline 04. & Outro atributo que considera relevante para c critério "Infraestrutura e Aspectos Regionais": & \\
\hline
\end{tabular}

04. Outro atributo que considera relevante para o critério "Infraestrutura e Aspectos Regionais":

Para comparar o que você considera importante entre os dois atributos em relação ao critério "Análise de Viabilidade Econômica":

\begin{tabular}{|clr|c|c|}
\hline 01. & "VPL" & em relação $\quad$ "Quantificação e qualificação dos custos fixos e variáveis" & Criticamente melhor \\
\hline 02. & Outro atributo que considera relevante para o critério "Análise de Viabilidade Econômica": & \\
\hline
\end{tabular}

Para comparar o que você considera importante entre os dois atributos em relação ao critério "Capacidade e Eficiência Operacional":

\begin{tabular}{|c|c|c|c|c|}
\hline 01. & "Capacidade estática" & em relação & "Eficiência dos sistemas e linhas de processamento" & Criticamente melhor \\
\hline 02. & "Capacidade estática" & em relação & "Utilização (Giros de Armazém)" & \\
\hline 03. & "Capacidade estática" & em relação & "Qualidade do Produto" & \\
\hline 04. & "Utilização (Giros de Armazém)" & em relação & "Eficiência dos sistemas e linhas de processamento" & \\
\hline 05. & "Utilização (Giros de Armazém)" & em relação & "Qualidade do Produto" & \\
\hline 06. & "Qualidade do Produto" & em relação & "Eficiência dos sistemas e linhas de processamento" & \\
\hline 07. & \multicolumn{4}{|c|}{ Outro atributo que considera relevante para o critério "Capacidade e Eficiência Operacional": } \\
\hline \multicolumn{5}{|c|}{ AGRADEÇO A SUA PARTICIPAÇÃO! } \\
\hline
\end{tabular}

Figura 33 - Questionário enviado para os tomadores de decisão. 
APÊNDICE B - Resultados dos questionários sobre os atributos

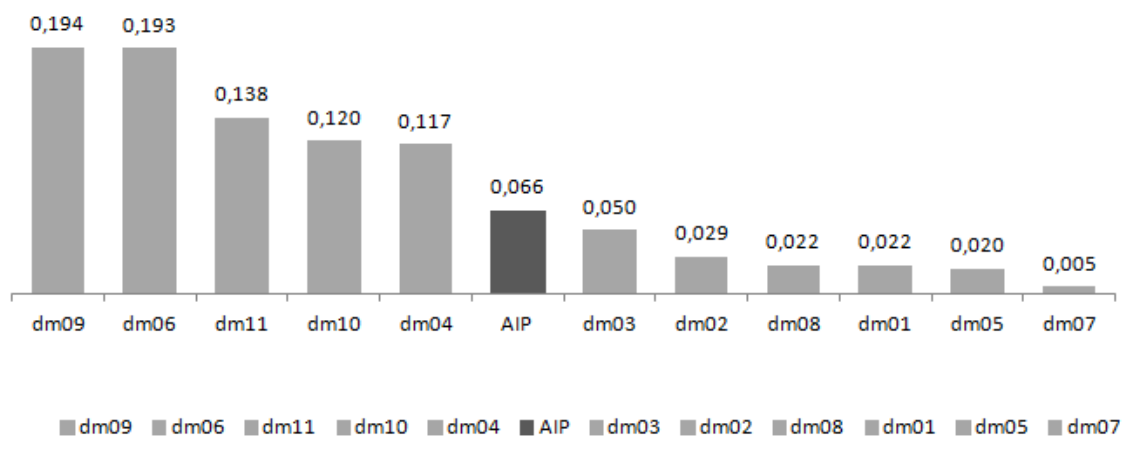

Figura 34 - Resultado dos decisores referente ao atributo "localização"

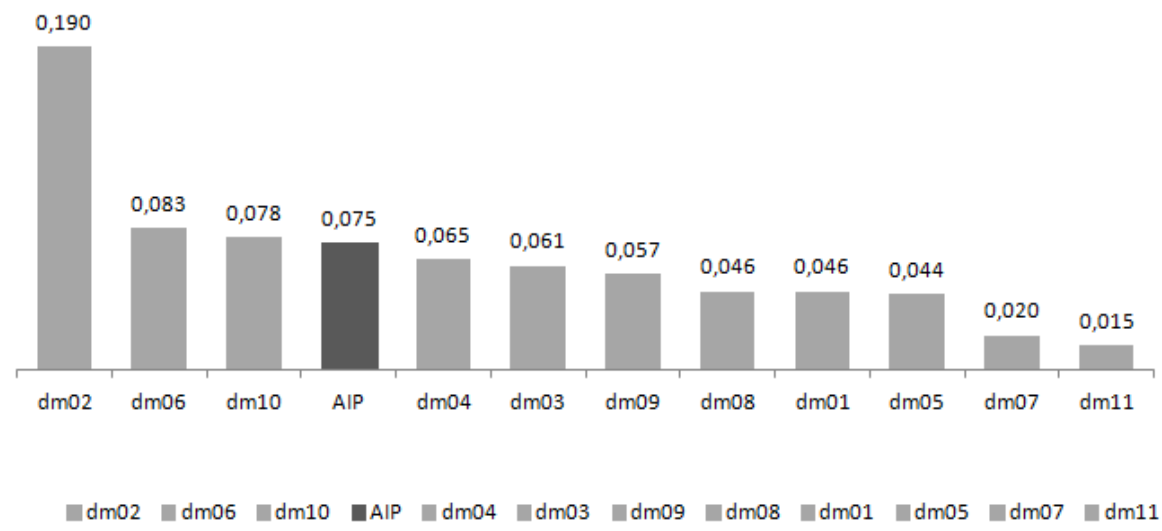

Figura 35 - Resultado dos decisores referente ao atributo "preço de frete da região"

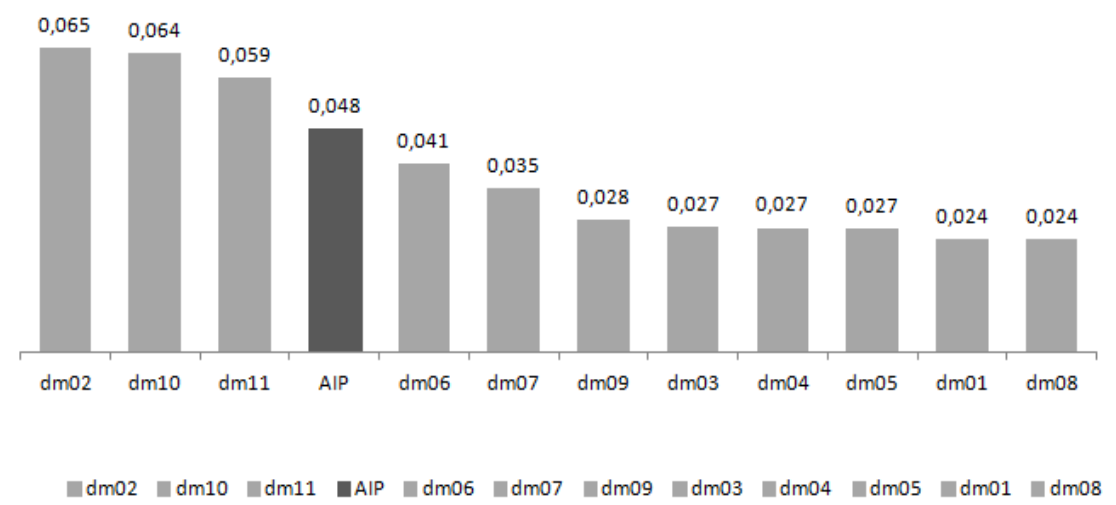

Figura 36 - Resultado dos decisores referente ao atributo "frota disponível na região" 


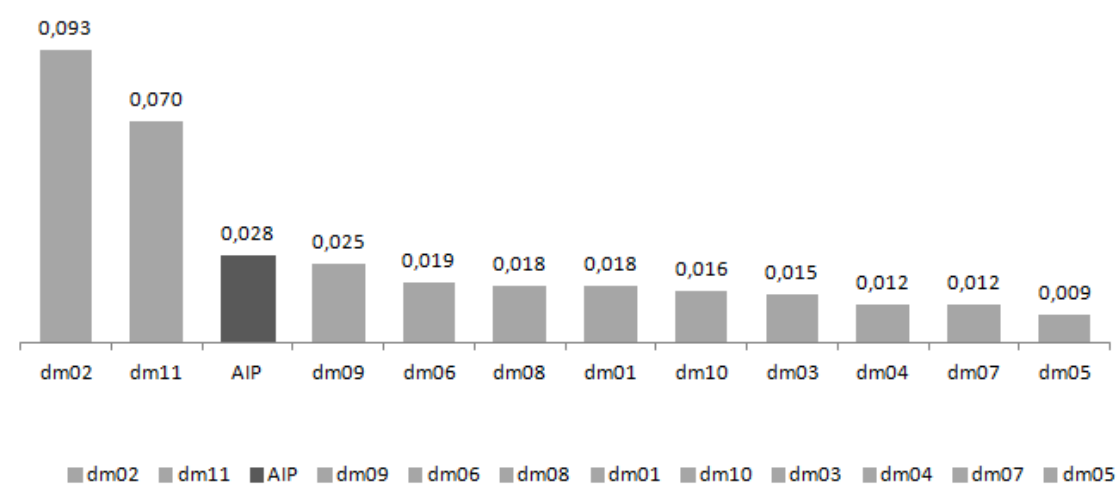

Figura 37 - Resultado dos decisores referente ao atributo "Modais de recepção e expedição"

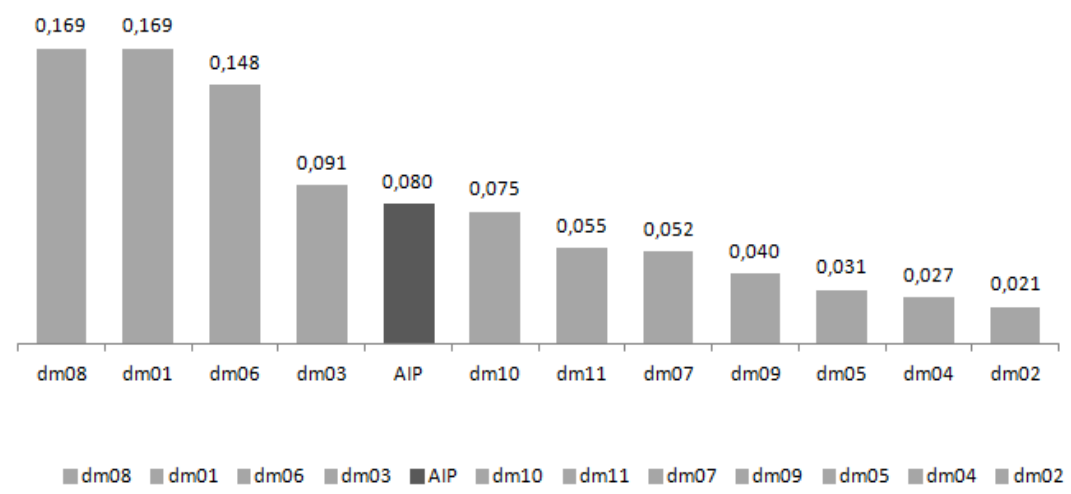

Figura 38 - Resultado dos decisores referente ao atributo "Concorrência"

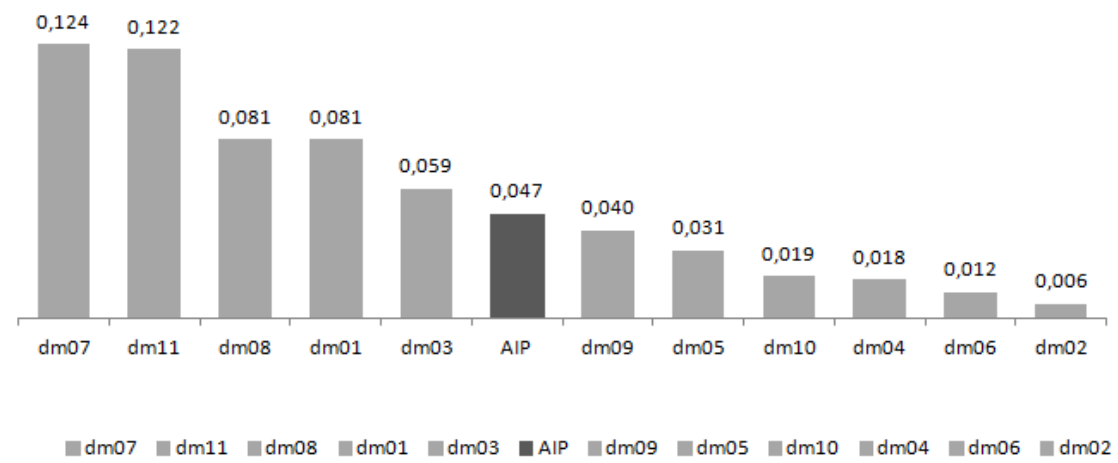

Figura 39 - Resultado dos decisores referente ao atributo "Aumento de Produção (Oferta)" 


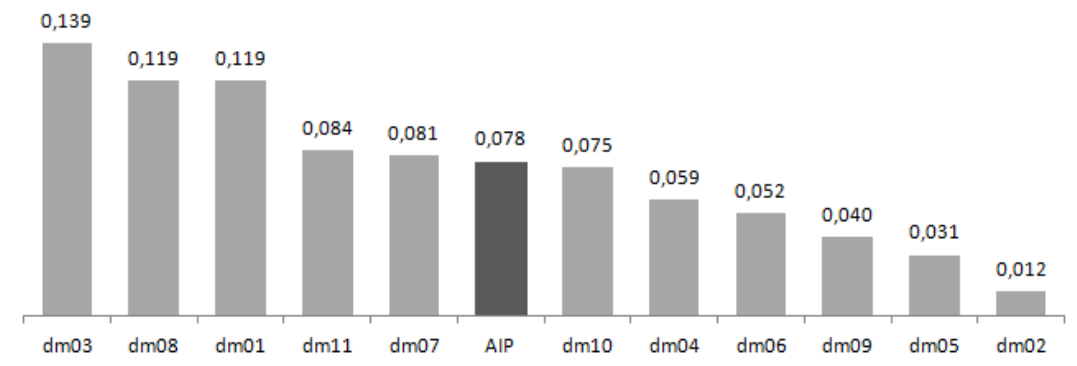

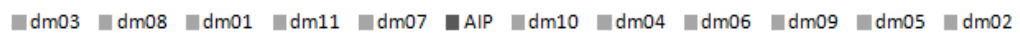

Figura 40 - Resultado dos decisores referente ao atributo "Demanda de Produto"

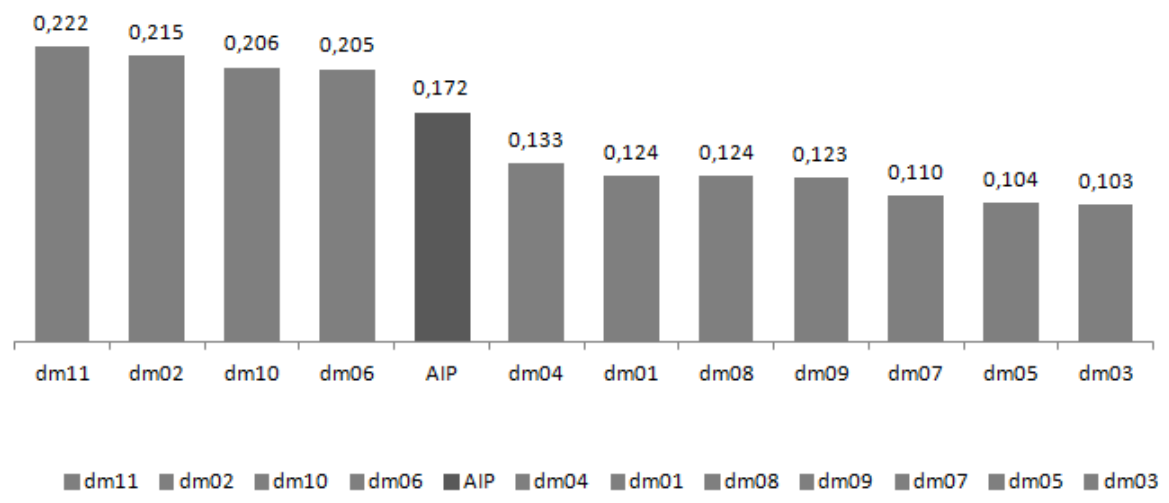

Figura 41 - Resultado dos decisores referente ao critério "Infraestrutura e aspectos agrícolas regionais"

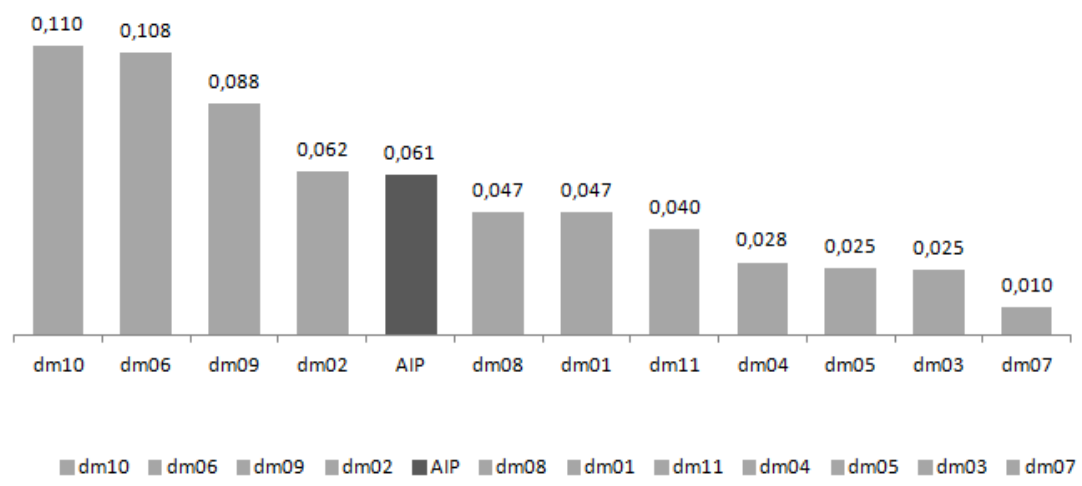

Figura 42 - Resultado dos decisores referente ao atributo "Aspectos agrícolas" 


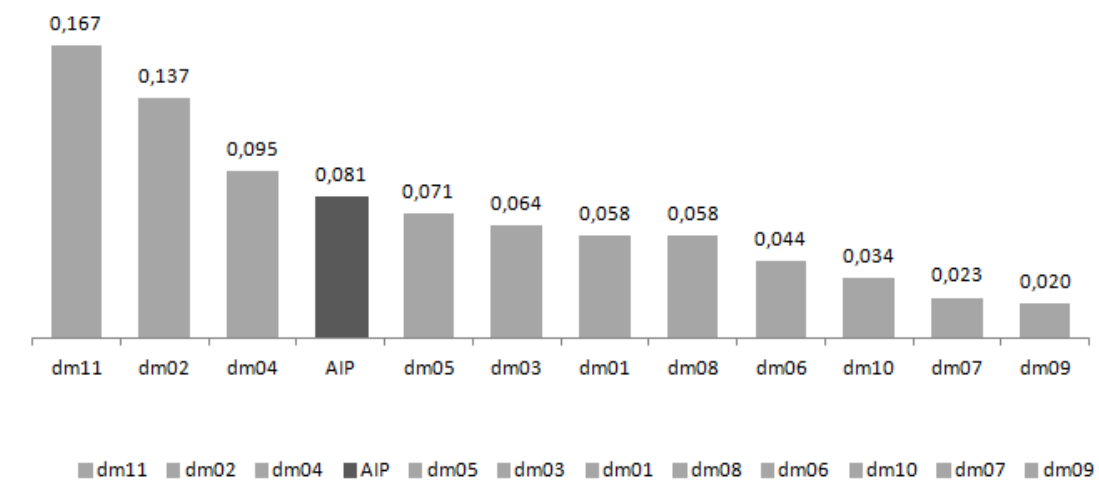

Figura 43 - Resultado dos decisores referente ao atributo "Demanda de Armazenagem"

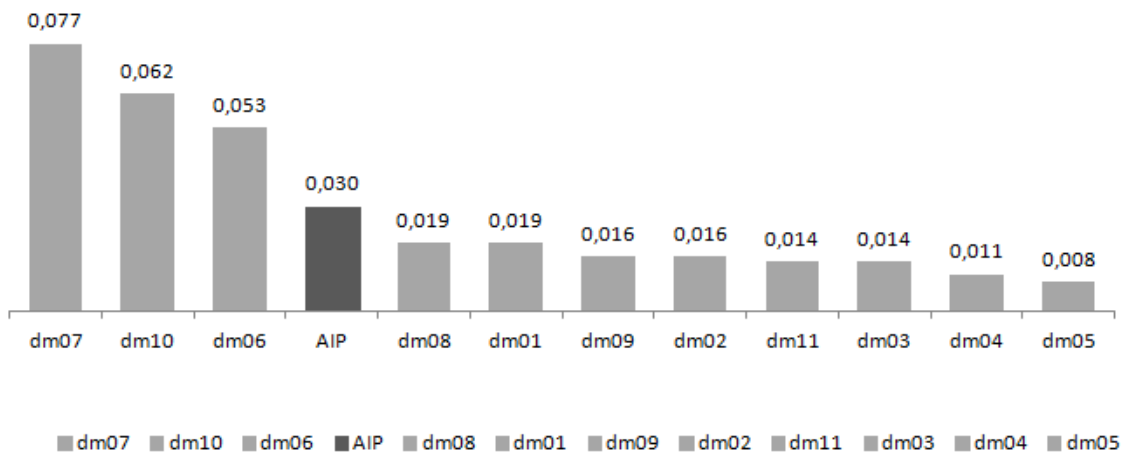

Figura 44 - Resultado dos decisores referente ao atributo "Aspectos Sociais"

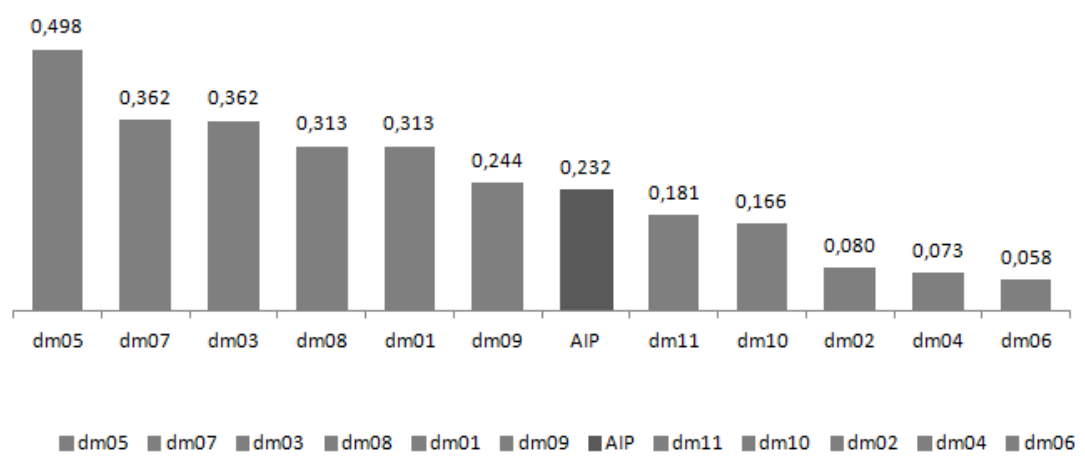

Figura 45 - Resultado dos decisores referente ao critério "Análise de Viabilidade Econômica" 


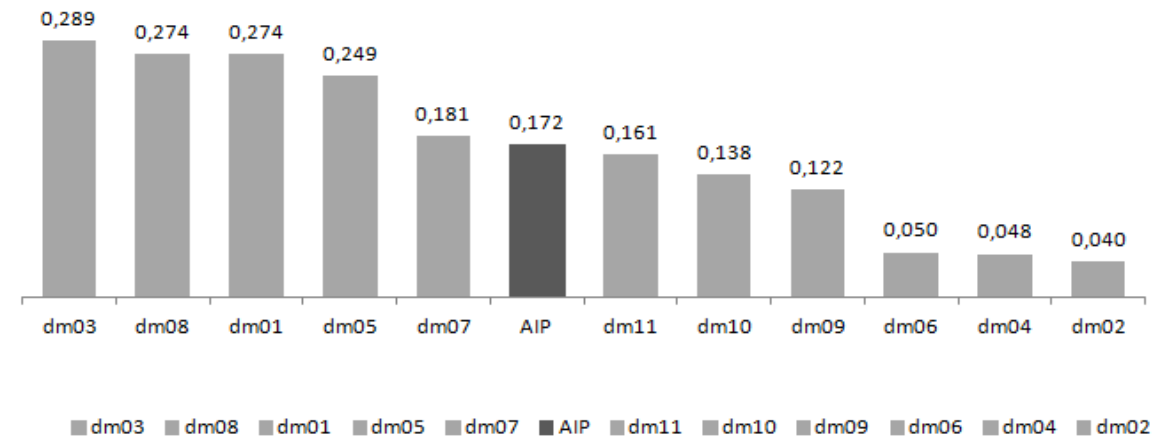

Figura 46 - Resultado dos decisores referente ao atributo "VPL"

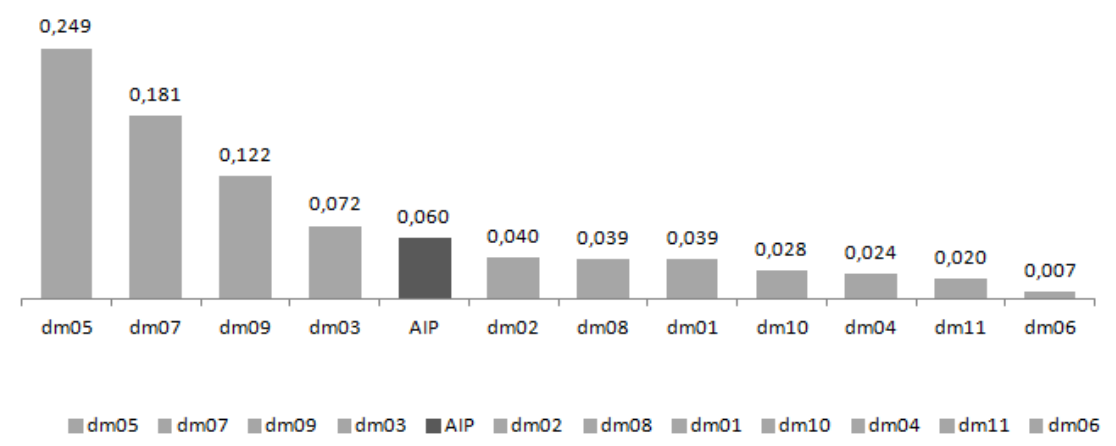

Figura 47 - Resultado dos decisores referente ao atributo "Quantificação e qualificação dos custos fixos e variáveis"

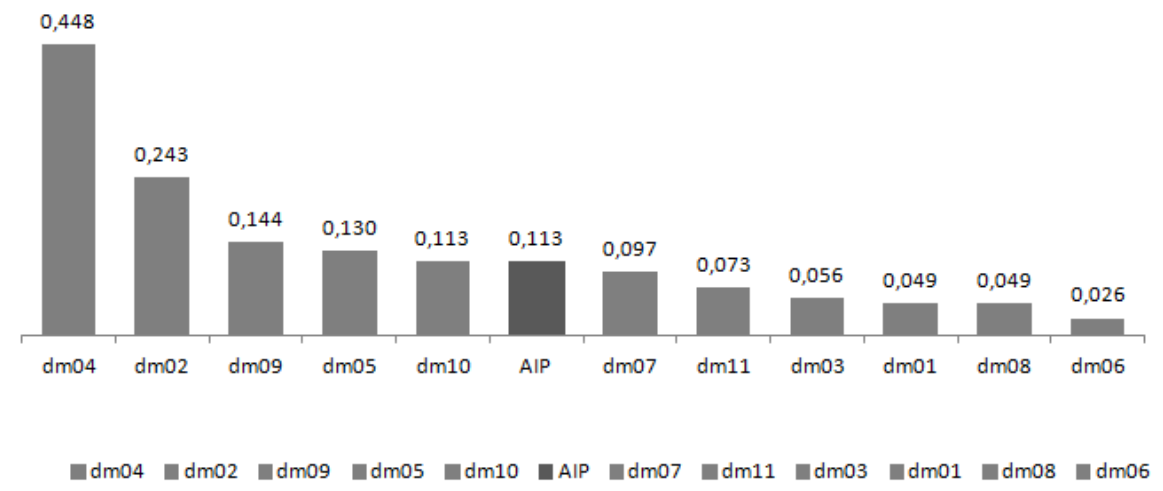

Figura 48 - Resultado dos decisores referente ao critério "Capacidade e Eficiência Operacional" 


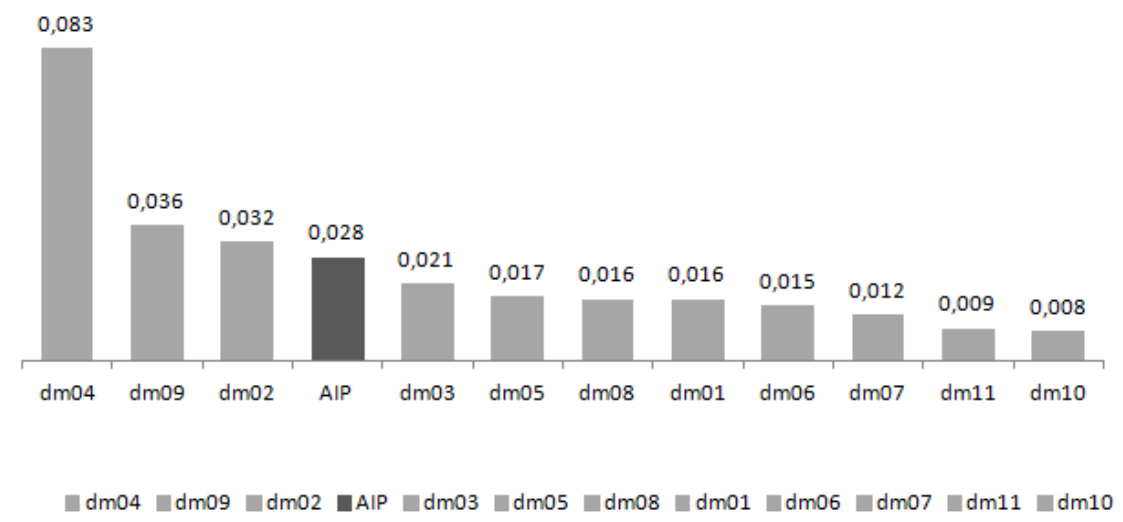

Figura 49 - Resultado dos decisores referente ao atributo "Capacidade estática"

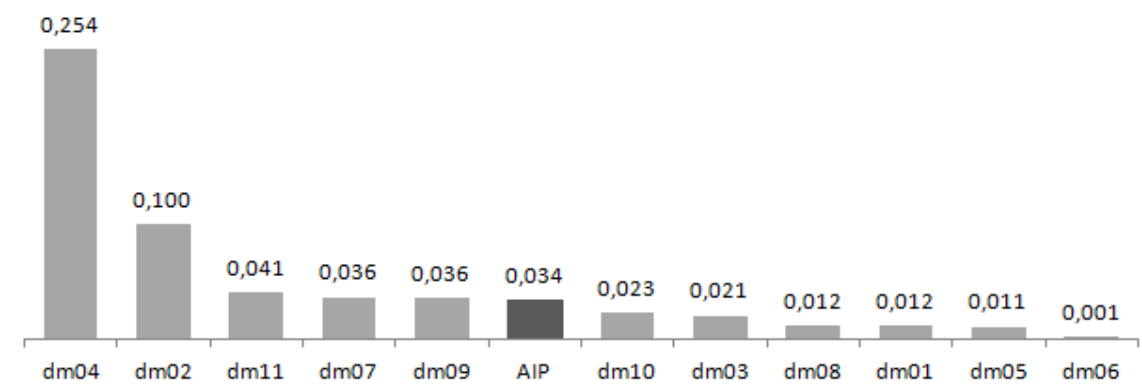

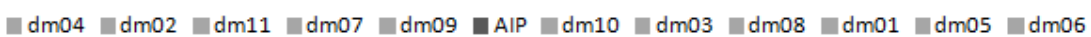

Figura 50 - Resultado dos decisores referente ao atributo "Eficiência dos sistemas e linhas de processamento"

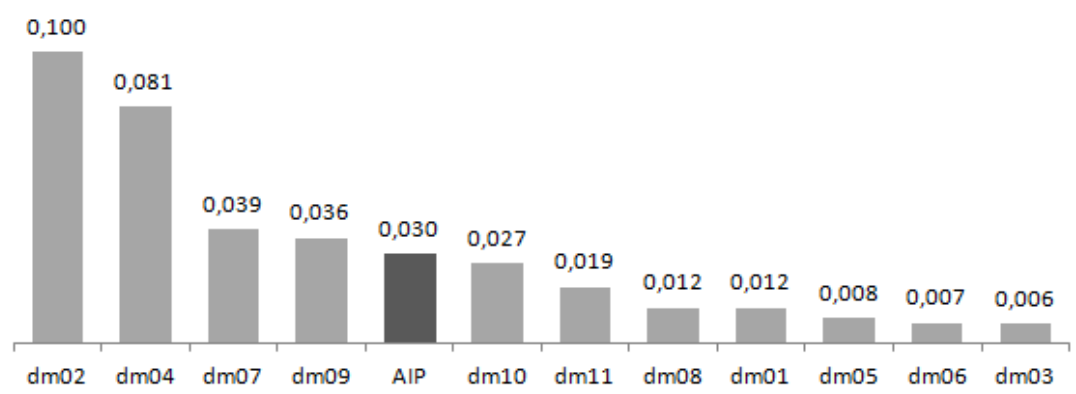

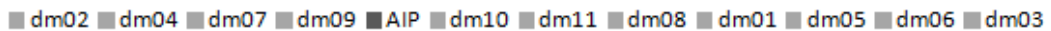

Figura 51 - Resultado dos decisores referente ao atributo "Utilização (Giros de Armazém)" 


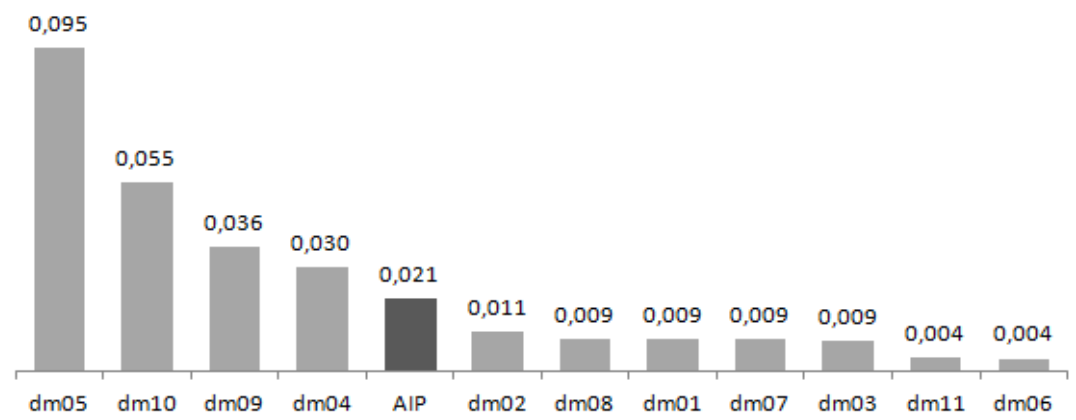

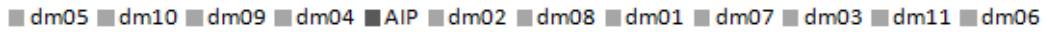

Figura 52 - Resultado dos decisores referente ao atributo "Qualidade do Produto" 